\title{
A Lower Cretaceous nannofossil zonation for the North Sea Basin
}

\author{
JASON JEREMIAH \\ Nederlandse Aardolie Maatschappij B.V., Schepersmaat 2, PO Box 28000, 9400 Assen, Netherlands.
}

\begin{abstract}
Analysis of cored sections from the Central North Sea Basin, boreholes from the onshore Netherlands and onshore sections from the UK and Germany has enabled a major reappraisal of Lower Cretaceous nannofossil datums. The Lower Albian to Upper Barremian interval has, in particular, been comprehensively amended. Five new species, Crucibiscutum bosunensis sp. nov., Crucibiscutum ryazanicum sp. nov., Lithraphidites houghtonii sp. nov., Seribiscutum dentatum sp. nov., Staurolithites palmula sp. nov. and one new sub-species, Biscutum constans cavum ssp. nov. are described. J. Micropalaeontol. 20(1): 45-80, July 2001.
\end{abstract}

\section{INTRODUCTION}

This paper has its foundations in calibration work carried out on some of the most important Lower Cretaceous reservoir sections in the North Sea Basin, namely the Aptian-Albian successions of the Britannia, Captain, Blake and Goldeneye fields. A detailed calibration was essential if basin-wide facies maps, sequence and seismo-stratigraphic markers were to be interpreted consistently around the basin (Jeremiah, 2000). Inherent weaknesses were identified at an early stage between the accepted lowermost Albian through Upper Barremian calibration of palynological and nannofossil events (e.g. nannofossil data often suggested a much higher top Lower Aptian than palynological data). The discrepancies were explained by the lack of extensive Lower Albian to uppermost Barremian nannofossil studies that had been calibrated to ammonite-dated material. Palynological datums from an ammonite calibration perspective were at a more advanced stage (Duxbury, 1983; Heilmann-Clausen \& Thomson, 1995).

The most recent Boreal zonation of Bown et al. (1998) was a compilation of previous works, mainly by Jakubowski (1987), Crux (1989, 1991) and Jeremiah (1996) with additional Ryazanian to Lower Barremian resolution provided from the unpublished $\mathrm{PhD}$ thesis of Rutledge and offshore data of Gallagher. The Upper Barremian to Lower Albian interval, however, remained poorly calibrated. A field-scale subdivision of the Late Barremian to Early Aptian (BC16 through BC20) of the Britannia Field by Gallagher in Bown et al. (1998), although documenting many of the important datums, only resulted in highlighting the poor macrofossil control available at this time. This paper attempts to re-address this primary weakness in the Boreal nannofossil zonation. Calibration to both palynological and macrofossil data has allowed this section to be re-evaluated.

A number of important onshore UK sections are first described, including the Lower Aptian strata from the Speeton section (Mitchell \& Underwood, 1999), the overlying Albian to Lower Cenomanian Red Chalk section at Speeton (Mitchell, 1995) and Upper Barremian-dated Speeton Clay from the BGS West-Heslerton II borehole. Supplementary UK nannofossil data are provided from the Lower Aptian Atherfield Clay in the $\mathrm{RC} 1544$ borehole, a sequence which is poorly calcareous at outcrop on the Isle of Wight (Bischoff \& Mutterlose, 1998). The Aptian nannofossil zonation is further constrained by various ammonite-dated sections from the Saxony Basin (Netherlands and Germany) and an isolated oucrop from the UK (Baulking Quarry). Nannofossil data from German sections are described in the Appendices. A brief review of the main sections studied is followed by a detailed breakdown of the new ammonite zonation. The differences between the interpreted ranges and utilization of alternative markers has made it more practical to establish another zonation rather than simply amend the BC Zonation of Bown et al. (1998). The zones are numbered downwards, a reference to this zonation having primarily been constructed for offshore studies. The zonation makes particular use of quantitative events. With more sections, both onshore and offshore having been studied, it is apparent that many previous zonal markers (e.g. Prediscosphaera columnata, Farhania varolii, Diazomatolithus lehmanii) have sporadic occurrences outside published ranges. The nannofossil distribution charts are biased towards the Aptian to Upper Barremian intervals, the stratigraphical interval that is most important from a North Sea, Lower Cretaceous reservoir perspective.

\section{METHODS}

\section{Sample preparation}

For light microscope examination, the samples were prepared by placing a small amount of sediment directly onto a microscope slide. A pipette was used to place a drop of distilled water onto the sample and smeared out into a thin layer by using a clean picking brush (size 101). The smeared sample was dried on a hot plate and a coverslip was attached using a permanent-mounting medium (Norland Optical Adhesive or Canada balsam). The picking brush is placed in $10 \% \mathrm{HCl}$ to remove any remaining residue.

\section{Counting technique}

Samples were examined with a light microscope at a magnification of $1000 \times$. A transect of thirty fields of view is taken with all specimens counted. Some species (e.g. Watznaueria barnesae) are so profuse that only ten or, in some instances, five fields of view are counted. Its abundance is subsequently multiplied out to thirty fields of view.

The following relative abundance categories which are used extensively in industry are also utilized in the present study:

rare: less than 1 specimen per 30 fields of view but present on scanning. 


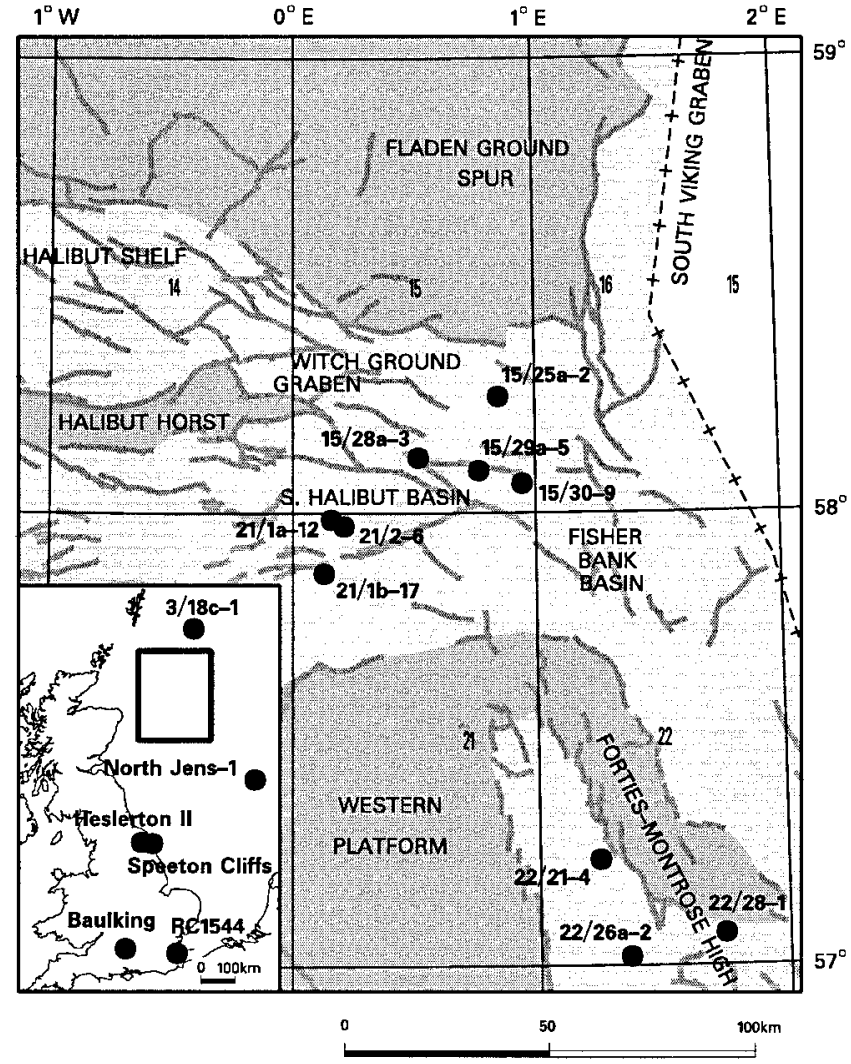

Fig. 1. Location map of sections analysed from North Sea Basin and onshore UK. Note the light shaded area in the large-scale UK map indicates the major Jurassic depocentres and criteria for differentiation of the various sub-basins utilized in the UK North Sea.

occasional: 1-2 specimens per 30 fields of view. common: 3-10 specimens per 30 fields of view. abundant: 11-30 specimens per 30 fields of view.

influx: individuals are a major component of assemblage greater than 1 specimen per field of view.

The distribution charts abundance counts are based upon a transect of 30 fields of view. $\mathrm{P}$ refers to present outside this initial count while $\mathrm{R}$ refers to reworked. The main markers on each distribution chart are highlighted with an asterisk.

\section{MATERIAL STUDIED}

The stratigraphic results presented here are based on data from several localities in England, the Netherlands and Germany, together with released data from numerous North Sea exploration wells. The locations of field samples studied from mainland UK and North Sea wells are indicated on Figure 1. Precise locations of UK outcrop localities are cited below, relative to the UK national grid. The German outcrop sections and Netherlands onshore wells are referenced in the Appendices. Co-ordinates are also given for all Netherlands onshore boreholes discussed in the text. A chronostratigraphic synopsis of the studied localities is given in Figure 2.

\section{Well and outcrop listing}

- North Sea Basin (11): 3/18c-1, 15/25a-2, 15/28a-3, 15/29a-5, 15/30-9, 21/1b-17, 22/21-4, 22/26a-2, 22/28a-1, Danish North
Jens-1, Norway 31/3-3. These data are complemented by nannofossil data from 17 cored wells and 13 non-cored sections from throughout the UK North Sea Basin (Jeremiah, 2000).

- Netherlands onshore boreholes (6): Spijkenisse-1, Sleen Dommerskanaal-1, Wijk-5, Beilen-2, Tubbergen-6 and Westerbork-1.

- UK onshore sections and boreholes (5): Speeton Cliffs, Heslerton II borehole, RC1544 borehole, Baulking Quarry, Isle of Wight.

- German onshore sections and boreholes (7): Suddendorf, Vohrum, Sarstedt, Rothenberg, Gehrdener-Berg, Alstatte and Kirchrode II borehole.

The main UK onshore sections studied are discussed briefly in the following sections. Nannofossils recovered in these sections are presented in range charts (Figs 3-5) or in the Appendices.

1. Yorkshire - Speeton Cliffs (Red Chalk and Speeton Clay)

2. Yorkshire - Heslerton Borehole II (Speeton Clay)

3. Kent - Borehole RC1544 (Atherfield Clay/Hythe Beds)

Speeton (Red Chalk) [TA 155 755]. The Red Chalk at Speeton (Fig. 3) is divided into five lithostratigraphic members (Mitchell, 1995). The ammonite zonation, by inferrence, is based upon regionally correlatable bivalve and belemnite events. Ammonites are extremely scarce having only been recorded from the lower part of the Speeton Beck and Queen Rocks Member (Mitchell, 1995). The Albian to Cenomanian boundary at Speeton can be accurately placed by using a distinctive stable carbon isotope $\left(\delta^{13} \mathrm{C}\right)$ excursion which is also recognized at the expanded Albian to Cenomanian succession in the Vocontian Trough (Gale et al., 1996). Samples supplied by S. F. Mitchell and C. Underwood from the specific numbered beds of Mitchell (1995) were analysed for nannofossils. The results support much of the $\log$ correlation and regional unconformities presented in Mitchell (1995).

The main surfaces recorded are as follows.

1. The flooding surface that corresponds to the transition from the Speeton Clay into the Red Chalk lies close to the spathi-intermedius Subzonal boundary. Ammonites recovered from the top of the Speeton A Beds were identified as Hoplites spathi and Hamites spp. (Owen pers. comm., 1997). Belemnite evidence suggests an intermedius Subzone for the basal Red Chalk Queen Rocks Member at Speeton (Mitchell, 1995). This flooding surface also corresponds to the flooding of the Carstone over much of Norfolk, Lincolnshire and Humberside. Gault Clay sedimentation over much of southern Britain was established during this period.

2. The regional cristatum erosive event (Owen, 1972, 1975) is recorded at Speeton and lies at the Queen Rocks Bed 2-Bed 3 boundary. Uppermost Middle Albian sediments are absent.

3. The Breccia Nodule Bed of Jeans (1973, 1980) marks a regionally correlatable intra-auritus Subzonal hiatus at the base of the Dulcey Dock Member, Bed 5 (DD5). This hiatus is recorded at South Ferriby (Gaunt et al., 1992; Mitchell, 1995; Jeremiah, 1996), the Cambridgeshire Gault Clay (Mitchell, 1995; Jeremiah, 1996) and at the type Gault Clay 


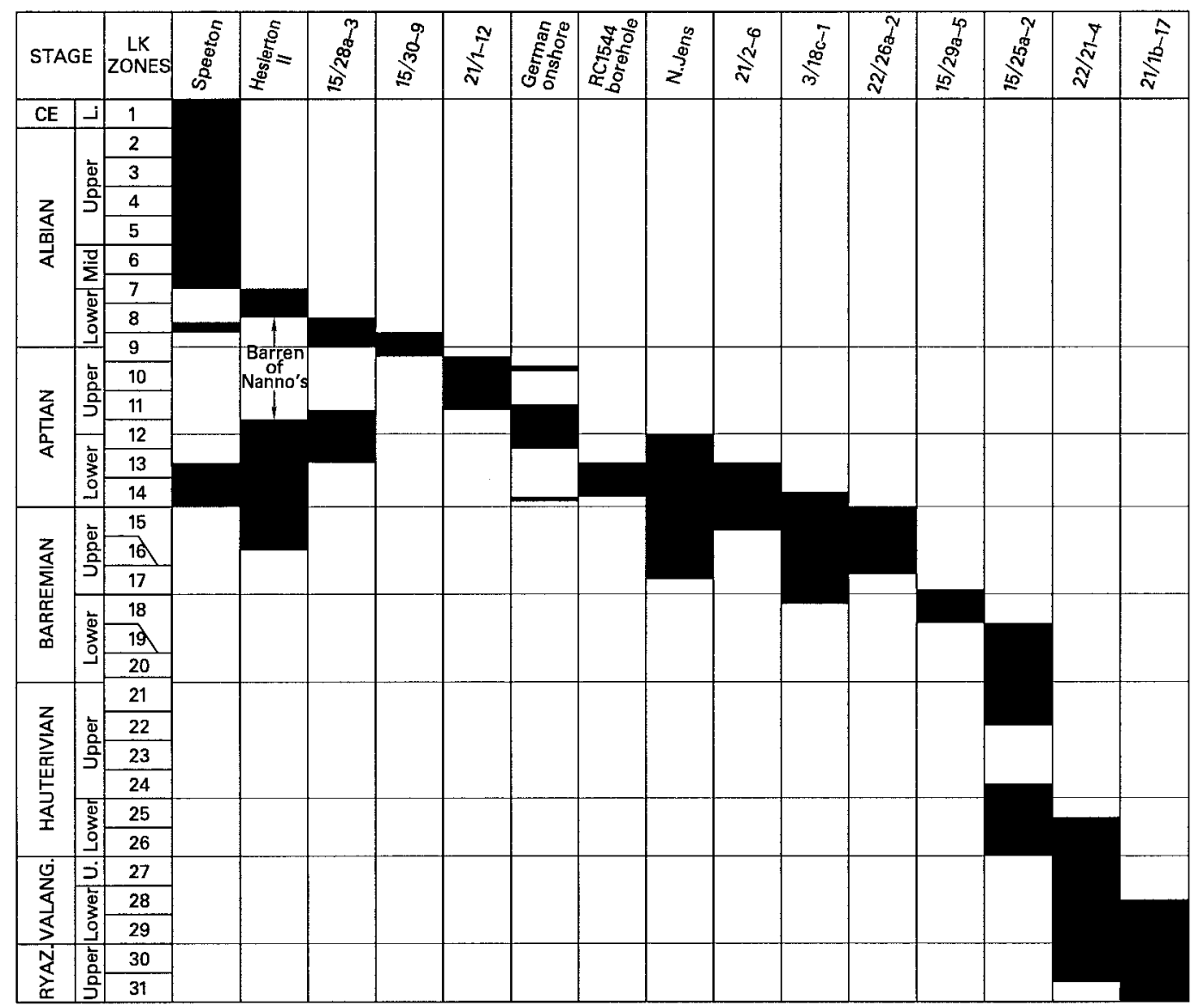

Fig. 2. Stratigraphic sections studied. Note the emphasis is on lowermost Albian to Upper Barremian sections. This stratigraphic interval was poorly calibrated to macrofossil stratigraphy in previous schemes.

succession at Folkestone (Jeremiah, 1996). At Folkestone the equivalent unconformity lies at the base of the Greensand Seam (Bed XII of Jukes-Browne \& Hill, 1900).

4. The presence of the Albian-Cenomanian boundary within the Weather Castle Member, Bed 7, is confirmed with nannofossil data.

Speeton (Speeton A \& B Beds). Samples collected by S. F. Mitchell and C. Underwood from the re-defined Speeton UB and LA Beds (Mitchell \& Underwood, 1999) were analysed for their calcareous nannofossil content (Fig. 4). Prolific ammonite data resulted in an accurate calibration of this Lower Aptian sequence. Uppermost Barremian bidentatum ammonite-bearing UB3 black claystones from immediately below the UB2 beds were also analysed (samples provided by P. Rawson). The dark grey marls and black mudstones of the Speeton UB2 and UB1 beds correlate directly with the Fischshiefer or Valhall V5 Beds (Johnson \& Lott, 1993) of the North Sea Basin, based on nannofossil data. Organic mudstones typical of the Fischschiefer are mostly absent from the Speeton section. This lateral facies change is also present in the West Netherlands Basin, onshore Netherlands, where Prodeshayesites-bearing mudstones also appear to lack any major organic mudstone intervals. The basal condensed LA6 bed, based on nannofossil data, correlates with the Valhall V6 (Ewaldi Marl) - Valhall V5 boundary in the
North Sea Basin. The pale marl deposits of the LA5 Beds, based on nannofossil data, can be directly correlated to the Valhall V6 Beds or Ewaldi Marl (Johnson \& Lott, 1993) of the North Sea Basin. The remaining Aptian sequence has yet to be recovered from the Speeton Cliffs, a result of the mud-slides which characterize this part of the exposure.

A possible indication of the post-Ewaldi Marl (LA5 beds) succession can be gauged from the West Heslerton II borehole. Lower Cretaceous syndepositional faulting (Kirby \& Swallow, 1987) may, however, have led to a considerable difference in these two successions.

West Heslerton borehole II (Speeton A \& B Beds) [SE 9199 7589]. This borehole, drilled by the British Geological Survey in 1991, covers a section from the Upper Albian Red Chalk down into the Upper Barremian B Beds (Appendix C). This stratigraphic interval, until recently, was poorly understood from the stratotype succession of the Speeton Clay at the Speeton Cliffs. Mitchell \& Underwood (1999) have recently documented the Lower Albian and Lower Aptian sequences from Speeton, but Upper Aptian and Upper Barremian successions have yet to be described as a result of non-exposure due to faulting and slumping.

Investigation of the West Heslerton II borehole has increased our understanding of the Lower Albian/Upper Barremian 


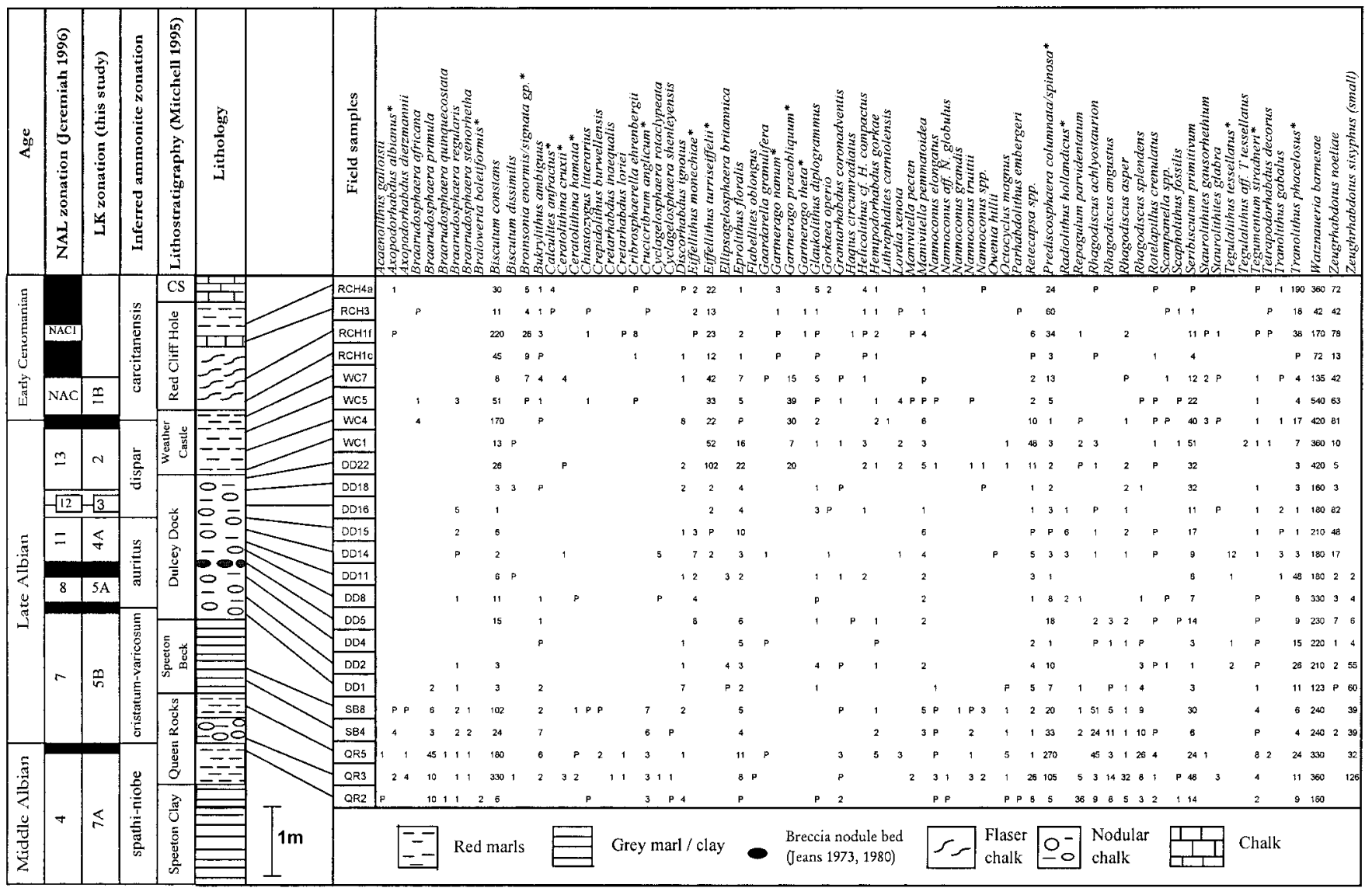

Fig. 3. Stratigraphical distribution of nannofossils from Speeton Cliffs (Red Chalk), Yorkshire. Field sample numbering scheme refers to the bed nomenclature of Mitchell (1995). CS refers to the Crowe's Shoot Member. Note the regional cristatum erosive event (Owen, 1972, 1975) at the base of Bed QR3, the intra-auritus hiatus at the Breccia Nodule Bed and the first indications of Zone LK1 within the early Cenomanian part of the upper Weather Castle Member.

sequence of the Speeton area. It should be emphasized, however, that variations in thickness and sedimentary expressions vary markedly north of the Howardian-Flamborough Fault Zone (Kirby \& Swallow, 1987). This can be proven by the markedly different field descriptions of temporary exposures at West Heslerton village by Ennis (1932) [SE 914 756] and Kaye (1964) [SE 914 756].

LCE Borehole RC1544 (Atherfield Clay/Hythe Beds) [142150N603315E/1:2500 Ordnance Survey]. This core penetrates a succession across the lower Hythe Beds (deshayesi Zone) to Atherfield Clay (forbesi Zone) boundary (Fig. 5). The Atherfield Clay succession penetrated is dominated by calcareous siltstones and dark grey mudstones that represent the initial Lower Aptian marine transgression over the non-marine Wealden Group (Ruffell \& Wach, 1991). The Atherfield Clay on the Isle of Wight is wholly of forbesi age, the underlying Perna Bed being equivalent to the upper part of the fissicostatus Zone. Further north in Kent, however, the Perna Bed is absent and it is considered possible that the Atherfield Clay extends into the fissicostatus Zone in this region. The Atherfield Clay is proven to correlate with the Fischschiefer (Valhall V5 Beds) of the North Sea Basin (Johnson \& Lott, 1993) by the presence of Nannoconus pseudoseptentrionalis and the Cyclagelosphaera margerelii acme. At Speeton, equivalent forbesi ammonitedated sediments have mostly been removed at the Speeton U1B/LA6 hiatus (Mitchell \& Underwood, 1999).

The lower Hythe Beds in the RC1544 borehole are correlatable with the Ewaldi Marl (Valhall V6 Beds) of the North Sea and the Speeton upper LA5 Beds described by Mitchell \& Underwood (1999) based on the presence of Eprolithus floralis below the FAD of Farhania varolii. At RC1544 the lower Hythe Beds are dominated by glauconitic clays, cemented limestones and calcareous sandstones, the so called 'Rag and Hassock' (Ruffell, 1992).

\section{ZONATION}

The zonation outlined below was developed as a practical tool for subdividing the uppermost Ryazanian to lowermost Cenomanian of onshore sections (mainly from England and Germany), borehole material from the Netherlands and offshore material from throughout the Central North Sea Basin (Fig. 1). Work was started, with the aim of improving the calibration of the Lower Albian to Upper Barremian BC scheme of Bown et al. (1998) and constructing a scheme useful for both academic and industrial purposes. In this study, 31 zones are defined for the uppermost Ryazanian to lowermost Cenomanian interval. 


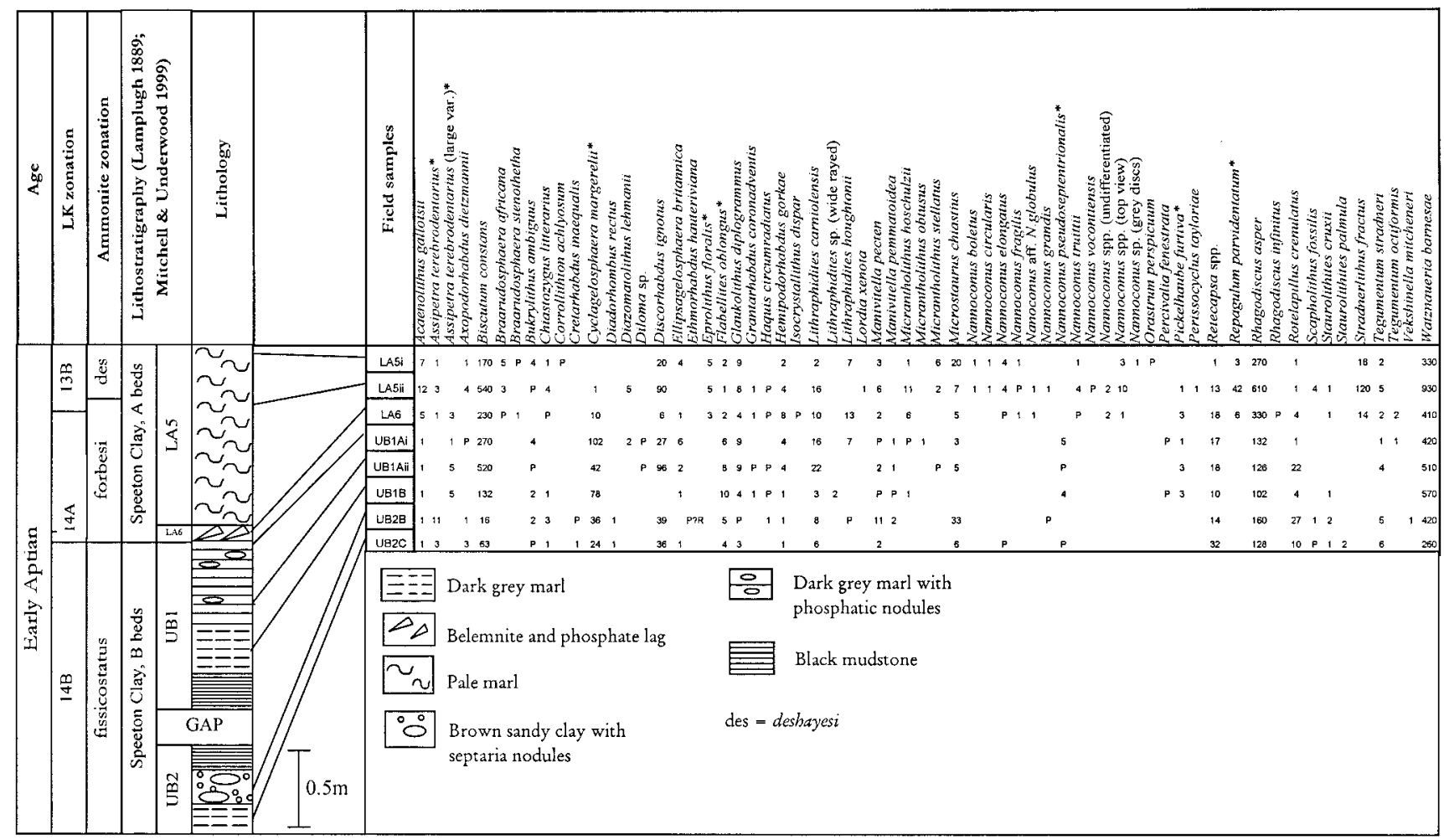

Fig. 4. Stratigraphical distribution of nannofossils from Speeton Cliffs (upper B/lower A Beds), Yorkshire. Note the absence of LK14B forbesi-dated sediments as a result of an intra-forbesi hiatus at Speeton (Bed LA6/Bed UB1 boundary).

Nine zones are defined for the first time (LK10, LK11, LK13, LK14, LK15, LK17, LK20, LK24 and LK31) and three zones are based on alternative zonal markers for the first time (LK12, LK25 and LK30). This study has also changed the stratigraphic significance of many established zonal markers. They are correlated with the macrofossil (MF) zones and compared with the previous BC zonation of Bown et al. (1998) in Figures 6 and 7. Composite range charts of biostratigraphically useful species are presented in Figures 8 and 9. FDO refers to first downhole occurrence, whilst LDO indicates the last downhole occurrence; the FAD being the first appearance datum or evolutionary appearance and LAD, the last appearance datum or extinction event.

\section{Broinsonia enormis Zone - LK1}

Top: LAD of Gartnerago praeobliquum [Jakubowski, 1986]. Base: FAD of occasional/abundant Broinsonia enormis/dentata group, Gartnerago theta, G. nanum and G. chiasta [Jeremiah, 1996].

Age: earliest Cenomanian (lowermost mantelli MF Zone, lower carcitanense Subzone), locally may range into the uppermost dispar MF Zone, uppermost perinflatum MF Subzone).

LK1 can be subdivided into two subzones.

\section{Subzone LK1A}

Top: LAD of Gartnerago praeobliquum [Jakubowski, 1986].

Base: FAD of Calculites anfractus [Jeremiah, 1996].

Age: earliest Cenomanian (lowermost mantelli MF Zone, lower carcitanense Subzone).
Remarks: Calculites anfractus has a well-defined FAD from UK onshore sections within the earliest Cenomanian; e.g. Arlesey, Eastbourne, South Ferriby (Jeremiah, 1996) and Speeton (Fig. 3). At Copt Point, Folkestone [TR 2414 3645], C. anfractus appears within the earliest Cenomanian, $2 \mathrm{~m}$ above the base of the Glauconitic Marl. An earlier FAD for Calculites anfractus was reported from the Boreal Late Albian by Bown et al. (1998) and Burnett (1998). The earlier FAD for C. anfractus in these studies was probably based on a solitary record $10 \mathrm{~m}$ below the base Cenomanian at the Tethyan Mt Risou section in southern France (Gale et al., 1996). This isolated occurrence would indicate an earlier FAD in southern France than in England for a nannofossil that exhibits marked Boreal provincialism. Jeremiah (1996), by contrast, analysed the same suite of samples as Gale et al. (1996) but identified the FAD and subsequent sporadic occurrences of C. anfactus $40 \mathrm{~m}$ above the Albian/Cenomanian boundary at Mt Risou.

\section{Subzone LK1B}

Top: FAD of Calculites anfractus [Jeremiah, 1996].

Base: FAD of occasional/abundant Broinsonia enormis/dentata group, Gartnerago theta, G. nanum and G. chiasta [Jeremiah, 1996].

Age: earliest Cenomanian (earliest mantelli MF Zone, early carcitanense Subzone), locally may range into the latest dispar MF Zone, latest perinflatum MF Subzone).

Note: the latest Albian Arrhaphoceras briacensis ammonite Subzone (Gale et al., 1996) is not utilized in this study since it it has 


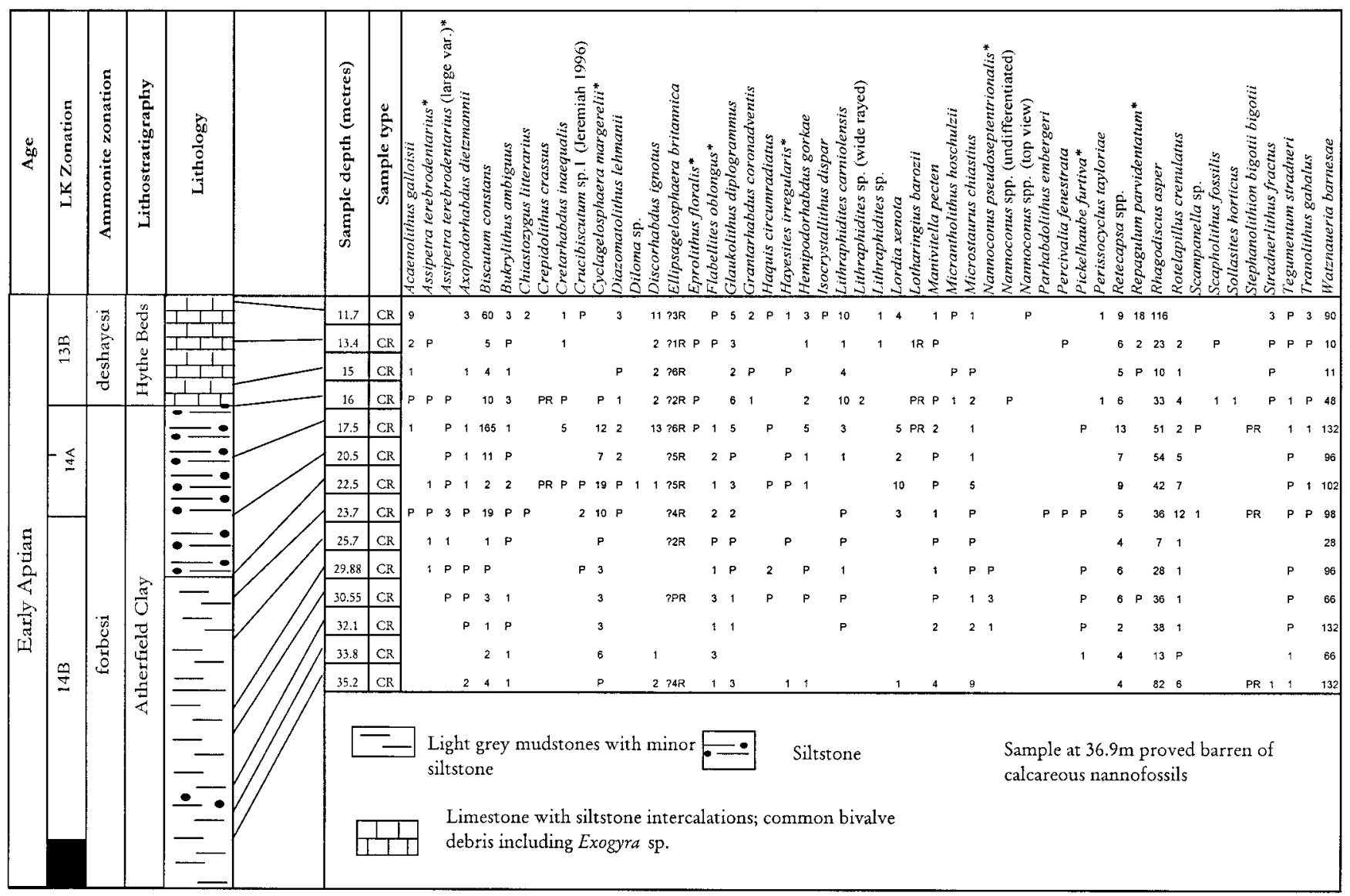

Fig. 5. Stratigraphical distribution of nannofossils from London Continental Engineering borehole RC1544, Ashford, Kent. Note the late Jurassic reworking including common Ellipsagelosphaera britannica. This section exhibits a more pronounced Tethyan influence than sections from the North Sea Basin. Note the consistent occurrences of Diazomatolithus lehmanii and Hayesites irregularis.

only been recognized, to date, in the southern European Tethyan Realm.

Remarks: the FAD of Gartnerago theta, G. nanum and G. chiasta associated with the increase in the Broinsonia enormis/dentata group coincides with the Albian-Cenomanian boundary in southern England; e.g. Arlesey, Folkestone (Jeremiah, 1996). In these exposures, however, the top Albian beds are truncated.

In the Red Chalk facies at Speeton (Fig. 3) the AlbianCenomanian boundary can be accurately placed by using a distinctive stable carbon isotope $\left(\delta^{13} \mathrm{C}\right)$ excursion (Mitchell, 1995) which is also recognized at the expanded AlbianCenomanian boundary successions documented from the Vocontian Trough, southern France (Gale et al., 1996). At Speeton, however, as in southern England localities, LK1 nannofossil assemblages remain restricted to the earliest Cenomanian. Currently, only at the Mt Risou section in southern France have LK1 assemblages been recorded from definitive uppermost Albian sediments (Gale et al., 1996; Jeremiah, 1996). In the Dutch Sector of the southern North Sea Basin and West of Shetland Basin similar expanded uppermost Albian sections (greater than $100 \mathrm{~m}$ ) as that developed at $\mathrm{Mt}$ Risou exist. It is from these areas that latest Albian LK1 assemblages, macrofossil recovery allowing, may be described from the Boreal Realm. The risks of provincialism and diachroneity remain, however, between the Boreal and Tethyan realms and, until otherwise proven, LK1 assemblages remain indicative of the earliest Cenomanian in the Boreal area.

Gartnerago chiasta and Crucibiscutum hayi are widespread within LK1 of southern Britain (e.g. Arlesey, Folkestone, Eastbourne and the Dutch Sector of the southern North Sea (Jeremiah, 1996) but are rarely recorded further north in the Red Chalk facies of Yorkshire (e.g. South Ferriby; Jeremiah, 1996, Speeton, Fig. 3) and the Central North Sea Basin.

\section{Eiffellithus turriseiffelii Zone - LK2}

Top: FAD of occasional/abundant Broinsonia enormis/dentata group, Gartnerago theta, G. nanum and G. chiasta [Jeremiah, 1996].

Base: LAD of Radiolithus hollandicus [Jeremiah, 1996].

Age: Late Albian (dispar MF Zone).

Remarks: the LAD of occasional/abundant Gartnerago praeobliquum (NLK3B of Jakubowski, 1987) is an approximate marker for the top of LK2 in the North Sea Basin. In southern Britain and Yorkshire sporadic incursions of common $G$. praeobliquum range into the basal Cenomanian, Zone LK1: e.g. Arlesey (Jeremiah, 1996) and Speeton (Fig. 3).

The LAD of Hayesites albiensis is recorded from the base of this zone in southern England (Folkestone Warren borehole, 
A Lower Cretaceous nannofossil zonation for the North Sea Basin

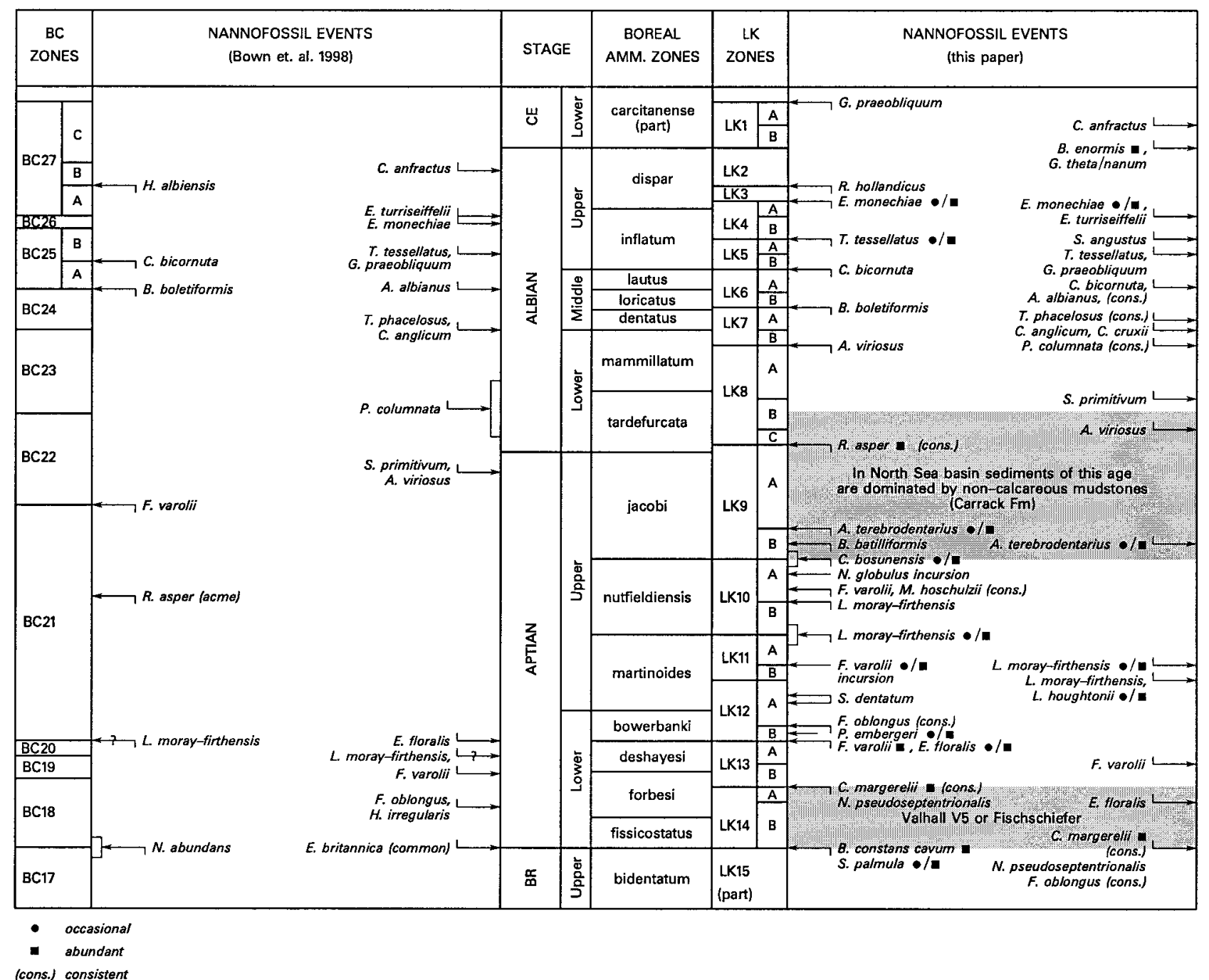

Fig. 6. Lowermost Cenomanian to uppermost Barremian nannofossil zonation scheme compared with Bown et al. (1998) scheme.

Jeremiah, 1996). This, though, is an extremely rare occurrence outside its normal UK stratigraphic range. It is more usual to find $H$. albiensis associated with varicosum Subzonal (intra inflatum Zone) to intra-mammillatum Zonal sediments (Chamberlain's Barn, Nine Acres Pit [Jeremiah, 1996] and Mundays Hill [Crux, 1991]). Hayesites albiensis appears to to be mostly restricted to southern England (exception being a single record from the West Heslerton II borehole; Jeremiah, 1996), a possible reflection of the Tethyan provincialism exhibited in this species.

\section{Radiolithus hollandicus Zone - LK3}

Top: LAD of Radiolithus hollandicus [Jeremiah, 1996]. Base: LAD of common Eiffellithus monechiae [this study]. Age: Late Albian (early dispar MF Zone, early rostratum MF Subzone).

\section{Staurolithites angustus Zone - LK4}

Top: LAD of common Eiffellithus monechiae [this study].
Base: LAD of common Tegulalithus tessellatus [this study] and FAD of Staurolithites angustus [Jeremiah, 1996].

Age: Late Albian (earliest dispar MF Zone, earliest rostratum MF Subzone/late inflatum MF Zone, late auritus Subzone).

Remarks: LK4 has been subdivided into two subzones.

\section{Subzone LK4A}

Top: LAD of common Eiffellithus monechiae [this study].

Base: FAD of common Eiffellithus monechiae [this study] and FAD of Eiffellithus turriseiffelii [Thierstein, 1976].

Age: Late Albian (earliest dispar MF Zone, earliest rostratum Subzone to late inflatum MF Zone, late auritus Subzone).

Remarks: the FAD of E. turriseiffelii has been used by many authors as an intra-Albian zonal marker (Thierstein, 1976; Sissingh, 1977 and, more recently, Bralower et al., 1993 and Bown et al., 1998). The FAD of E. turriseiffelii is, however, difficult to identify accurately due to the proliferation at this level of intermediates between E. monechiae and E. turriseiffelii. This is compounded by the extreme rarity of true E. turriseiffelii 


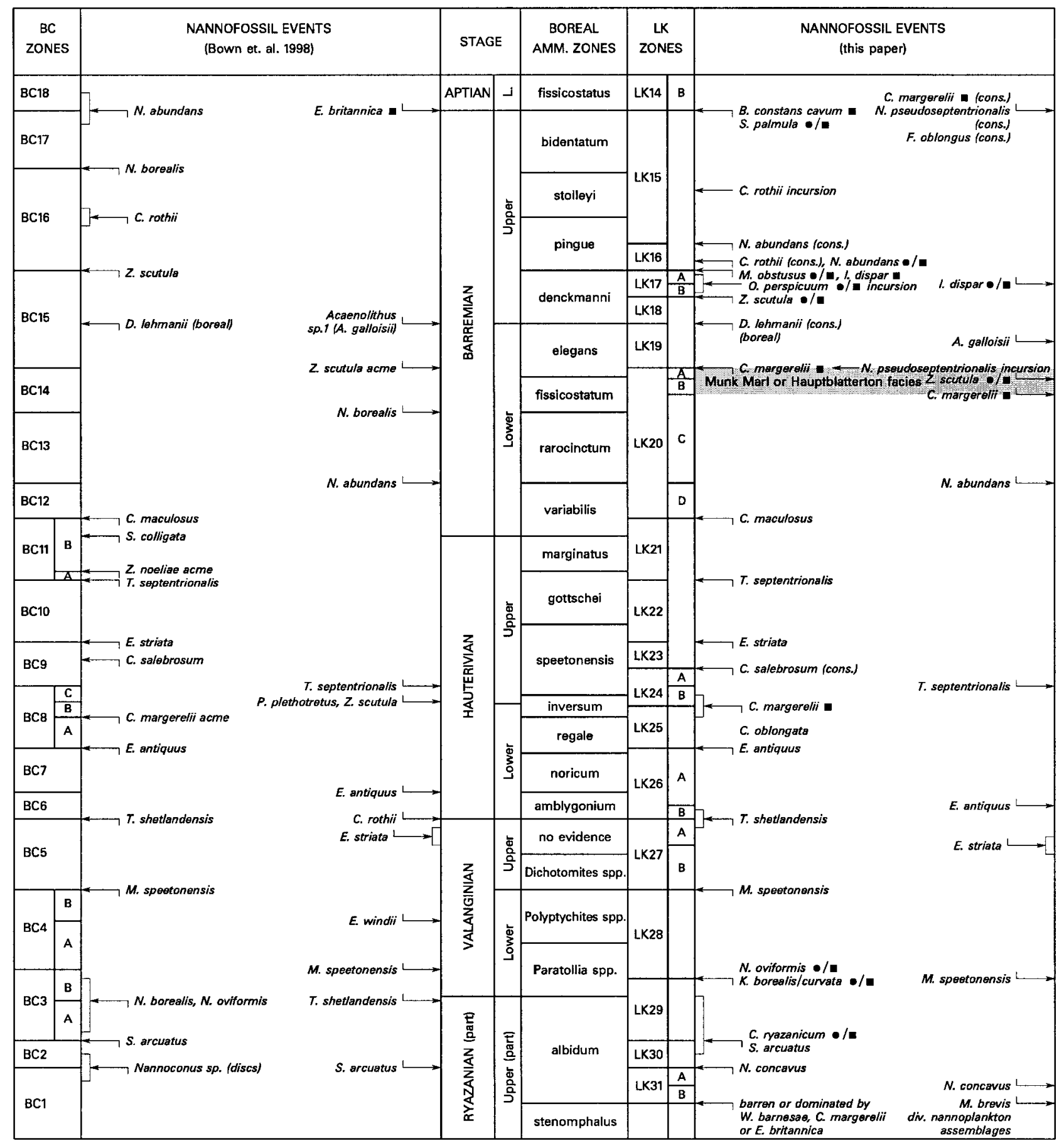

- occasional

- abundant

(cons.) consistent

Fig. 7. Lowermost Aptian to uppermost Ryazanian nannofossil zonation scheme compared with Bown et al. (1998) scheme.

at the base of its range and the necessity for well-preserved and diverse assemblages. These criteria are rarely attained in the North Sea Basin assemblages (note the absence from Speeton samples DD5-DD11, Fig. 3). The abundance increase in $E$. monechiae is a far more easily recognizable datum.
The FAD of E. turriseiffelii has been adjusted to lie within the uppermost auritus MF Subzone. This amendment to the zonation of Jeremiah (1996) is a result of the incorrect assignment of rostratum MF sediments at the Burwell section (samples B12-B16 should belong to Bed 16 of Gallois \& Morter, 1982). 

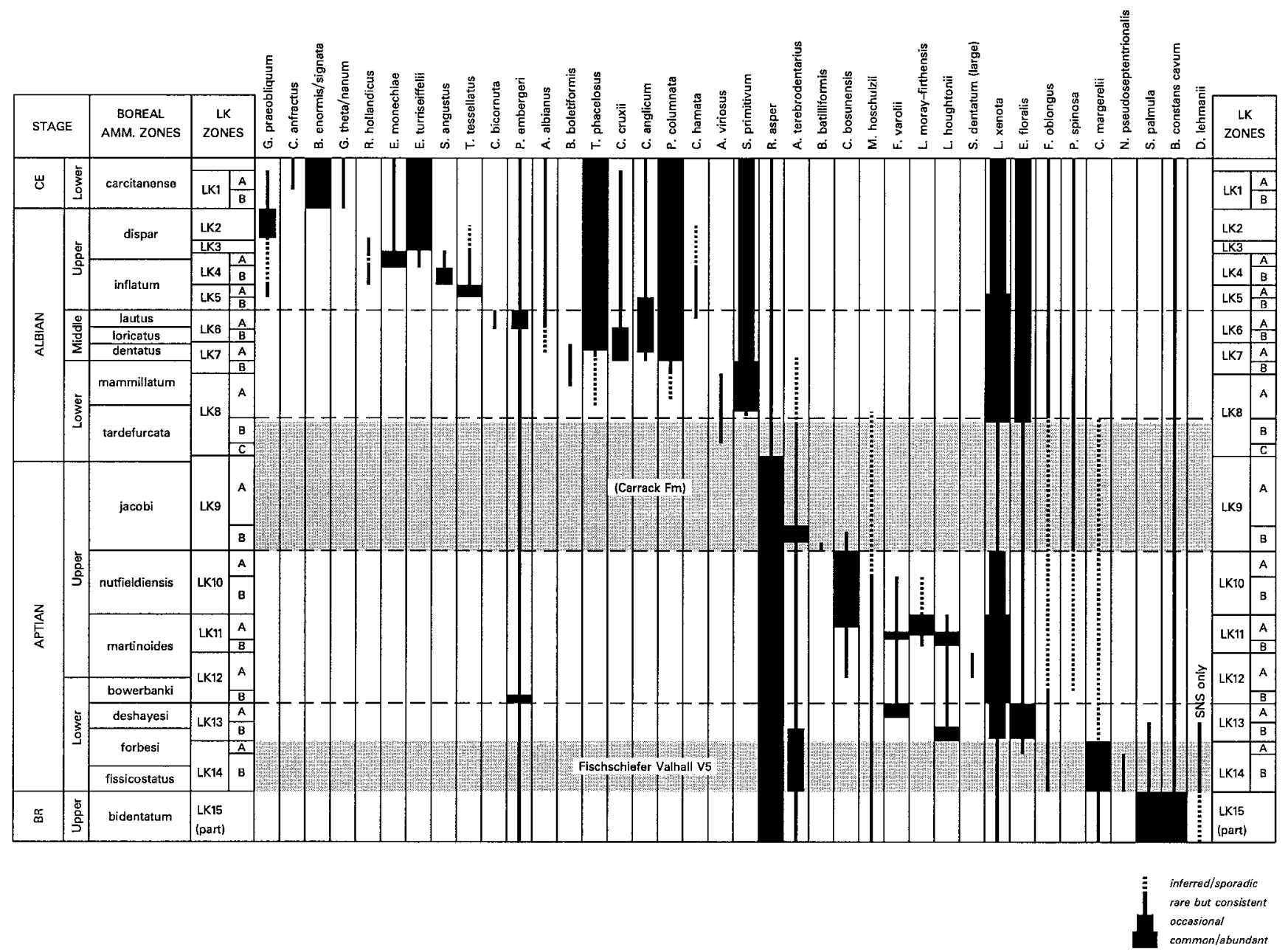

Fig. 8. Composite range chart of stratigraphically important lowermost Cenomanian to uppermost Barremian nannofossils of the North Sea Basin.

This refinement is confirmed by the presence of LK4A sediments of auritus age at Speeton (Fig. 3; samples DD14/DD15).

\section{Subzone LK4B}

Top: FAD of common Eiffellithus monechiae [this study] and FAD of Eiffellithus turriseiffelii [Thierstein, 1976].

Base: LAD of common Tegulalithus tessellatus [this study] and FAD of Staurolithites angustus [Jeremiah, 1996].

Age: Late Albian (late inflatum MF Zone, late auritus MF Subzone).

Remarks: Staurolithites angustus is restricted to LK4B in the North Sea Basin. Onshore, in southern Britain, S. angustus ranges into LK4A (NAL11 of Jeremiah, 1996). This species rapidly evolved into Staurolithites rotatus at the base of LK3 (Jeremiah, 1996). Anomalous records cited for S. angustus from the latest Albian to Cenomanian (Burnett, 1998) are probably due to the assignment of a plethora of smaller Staurolithites spp. to $S$. angustus.

A regional uppermost auritus unconformity is recorded from onshore UK (e.g. Folkestone, Burwell, South Ferriby) (Jeremiah, 1996) and Speeton (Fig. 3). In all instances sediments yielding the FAD datum of E. monechiae have been eroded. This subzone is also extremely condensed over much of the North Sea. To date, the evolutionary FAD of E. monechiae has only been documented from the Munday's Hill section, Bedfordshire (Crux, 1991; Jeremiah, 1996).

\section{Rhagodiscus splendens Zone - LK5}

Top: LAD of common Tegulalithus tessellatus [this study] and FAD of Staurolithites angustus [Jeremiah, 1996].

Base: LAD of Ceratolithina bicornuta [Jeremiah, 1996].

Age: Late Albian (inflatum MF Zone, auritus to cristatum MF Subzone).

Remarks: LK5 can be subdivided into two subzones.

\section{Subzone LK5A}

Top: LAD of common Tegulalithus tessellatus [this study] and FAD of Staurolithites angustus [Jeremiah, 1996].

Base: FAD of Tegulalithus tessellatus [Jeremiah, 1996] and Gartnerago praeobliquum [Jeremiah, 1996].

Age: Late Albian (inflatum MF Zone, auritus MF Subzone). 


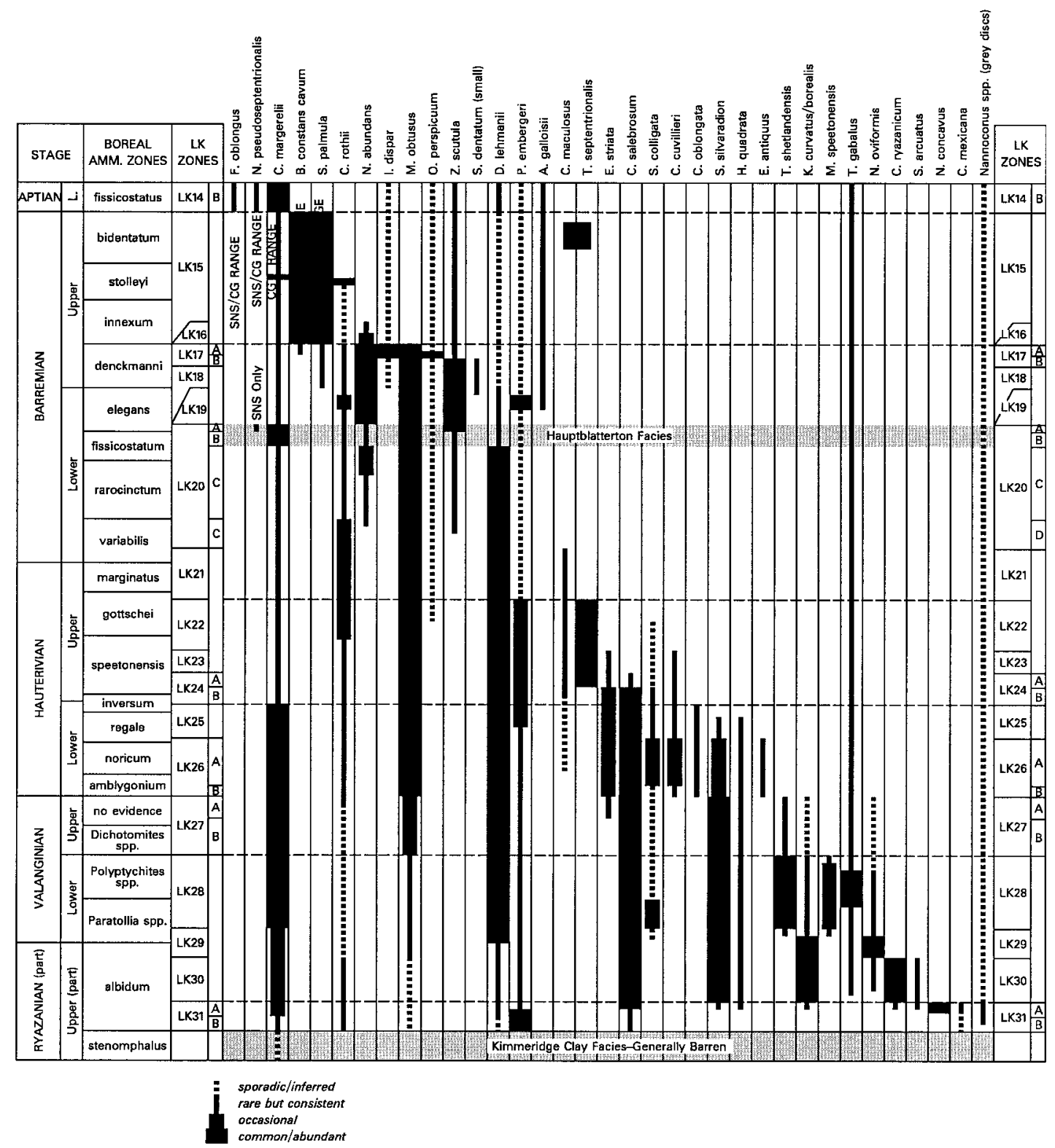

Fig. 9. Composite range chart of stratigraphically important lowermost Aptian to uppermost Ryazanian nannofossils of the North Sea Basin.

Remarks: at onshore UK sections (Burwell, Munday's Hill and Folkestone; Jeremiah, 1996) the quantitative acme of of $T$. tessellatus is recorded from this subzone. Sporadic incursions are recorded as high as LK4 (Burwell; Jeremiah, 1996 and Speeton; Fig. 3, sample DD14). In the lower abundance and diversity assemblages of the North Sea Basin common T. tessellatus are restricted to LK5A below the FAD of Staurolithites angustus. Crepidolithus burwellensis (large variety of Jeremiah, 1996) is restricted to LK5A.

\section{Subzone LK5B}

Top: FAD of Tegulalithus tessellatus [Crux, 1991] and Gartnerago praeobliquum [Jeremiah, 1996].
Base: LAD of Ceratolithina bicornuta [Jeremiah, 1996].

Age: Late Albian (early inflatum MF Zone, varicosum/cristatum MF Subzones).

\section{Crucicribrum anglicum Zone - LK6}

Top: LAD of Ceratolithina bicornuta [Jeremiah, 1996]. Base: LAD of Braloweria boletiformis [Crux, 1991].

Age: Middle Albian (lautus Zone, daviesi Subzone to late loricatus MF Zone, subdelaruei MF Subzone).

Remarks: LK6 is extremely condensed or absent over much of the North Sea and onshore Western Europe as a result of the cristatum erosive event (Owen, 1975). This zone can be subdivided into two subzones. 


\section{Subzone LK6A}

Top: LAD of Ceratolithina bicornuta [Jeremiah, 1996].

Base: FAD of consistent Axopodorhabdus albianus and FAD of Ceratolithina bicornuta [this study].

Age: Middle Albian (lautus Zone, daviesi Subzone to late loricatus MF Zone, meandrinus Subzone).

Remarks: The base of Subzone BC25a of Bown et al. (1998) is based upon the FAD of $A$. albianus. This form is, however, recorded sporadically as low as the intermedius Subzone (Amédro et al. 1981; Jeremiah, 1996; Jakubowski, pers. comm., 1999). The FAD datum of A. albianus, as utilized by Bown et al. (1998) probably equates to the top of Subzone LK6B as defined in the current study. Ceratolithina hamata and Owenia hillii have FADs within LK6A associated with occasional/common Parhabdolithus embergeri (Jeremiah, 1996). The range of $C$. bicornuta has been extended into the meandrinus Subzone based on ammonite-dated material from the Kirchrode II borehole, onshore Germany (Jakubowski, pers. comm., 1999).

\section{Subzone LK6B}

Top: FAD of consistent Axopodorhabdus albianus and LDO of Ceratolithina bicornuta [this study].

Base: LAD of Braloweria boletiformis [Crux, 1991]. Age: Middle Albian (upper loricatus MF Zone, subdelaruei Subzone).

\section{Braloweria boletiformis Zone - LK7}

Top: LAD of Braloweria boletiformis [Crux, 1991].

Base: LAD of Acaenolithus viriosus [Jeremiah, 1996].

Age: Middle Albian to latest Early Albian (loricatus MF Zone, niobe MF Subzone/latest mammillatum MF zone, steinmanni MF Subzone).

Remarks: LK7 can be subdivided into two subzones.

\section{Subzone LK7A}

Top: LAD of Braloweria boletiformis [Jeremiah, 1996].

Base: FAD of Ceratolithina cruxii [Jeremiah, 1996] and Crucicribrum anglicum [Jeremiah, 1996].

Age: Middle Albian (loricatus MF Zone, niobe MF Subzone to dentatus MF Zone, lyelli MF Subzone).

Remarks: the FAD of consistent Tranolithus phacelosus occurs within the lower part of the lyelli Subzone (Jeremiah, 1996; Jakubowski pers. comm., 1999). It is extremely rare at this level and is prone to etching within equivalent sections throughout the North Sea Basin and onshore UK sections. Extra care is required in differentiating $T$. phacelosus from Glaukolithus diplogrammus within the basal Middle Albian. Rare occurrences of T. phacelosus have been encountered within the Early Albian (Kennedy et al., 2000).

\section{Subzone LK7B}

Top: FAD of Ceratolithina cruxii [Jeremiah, 1996] and Crucicribrum anglicum [Jeremiah, 1996].

Base: LAD of Acaenolithus viriosus [Jeremiah, 1996].

Age: latest Early Albian (uppermost mammillatum MF Zone, steinmanni MF Subzone).

Remarks: Prediscosphaera columnata (restricted to the circular form of Prediscosphaera) has been utilized consistently by nannofossil workers as a zonal marker within the Albian
(Sissingh, 1977; Perch-Nielsen, 1979; and, more recently, Bown et al., 1998). The FAD of consistent $P$. columnata is found at the base of LK7B steinmanni ammonite-dated strata (Chamberlain's Barn section; Jeremiah, 1996 and Speeton, pers. obs.). Isolated occurrences of $P$. columnata have also been recovered from the upper part of LK8 (Bown et al., 1998; Jeremiah, pers. obs.). Jakubowski (pers. comm., 1999) recorded the FAD as low as the acuticostata Subzone (tardefurcata Zone) in the Kirchrode II borehole and Kennedy et al. (2000) cited an intra tardefurcata Zonal FAD. These isolated occurrences, however, are considered too sporadic to be utilized as a reliable correlative event. By contrast, core data from North Sea Well 14/29a-4 yielded the FAD of $P$. columnata at the base of the Middle Albian associated with the FADs of $C$. anglicum and $C$. cruxii. The late FAD of $P$. columnata in this area is probably a result of the decreased preservation and diversity compared to onshore sections. Caution should therefore be used in correlating the FAD of $P$. columnata as a global marker event. Its consistent FAD in close proximity to the Lower to Middle Albian boundary is useful but, as the comments above suggest, sporadic occurrences of this form range well down into the Lower Albian.

\section{Acaenolithus viriosus Zone - LK8}

Top: LAD of Acaenolithus viriosus [Jeremiah, 1996].

Base: LAD of abundant Rhagodiscus asper [Jakubowski, 1987]. Age: Early Albian (mammillatum/tardefurcata).

Remarks: LK8 can be subdivided into three subzones.

\section{Subzone LK8A}

Top: LAD of Acaenolithus viriosus [Jeremiah, 1996].

Base: FAD of Seribiscutum primitivum [this study].

Age: Early Albian (mammillatum Zone, bulliensis Subzone to latest tardefurcata MF Zone, late regularis MF Subzone)

Comments in the North Sea Basin common Parhabdolithus embergeri are characteristic of this subzone. Onshore, however, this event is also recorded from Subzone LK7B (Jeremiah, 1996; West Heslerton II borehole, Appendix C). The FAD of $S$. primitivum is confirmed by regularis ammonite-dated material from the Kirchrode II borehole, onshore Germany (Jakubowski, pers. comm., 1999). The intra-regularis FAD for S. primitivum is confirmed by its absence from regularis ammonite-dated sediments from the Speeton LA1 Beds (Mitchell \& Underwood, 1999) and the lower part of the regularis ammonite-dated sediments in the Kirchrode II borehole (Jakubowski, pers. comm., 1999). Kennedy et al. (2000) record the FAD of $S$. primitivum at the Tethyan Col de Pré-Guittard section from immediately below an incursion of D. mammillatum Zonal ammonites.

\section{Subzone LK8B}

Top: FAD of Seribiscutum primitivum [this study].

Base: FAD of Acaenolithus viriosus [Jeremiah, 1996].

Age: Early Albian (tardefurcata MF Zone, early regularis to late schrammeni MF Subzones).

Remarks: the basal part of the Rodby R1 Unit in the North Sea (Crittenden et al., 1991) is characterized by an influx of Repagulum parvidentatum, Acaenolithus galloisii and Tegumentum stradneri (Rothia striata of Jeremiah, 1996). This same assemblage (Appendix B) is recognized from regularis 


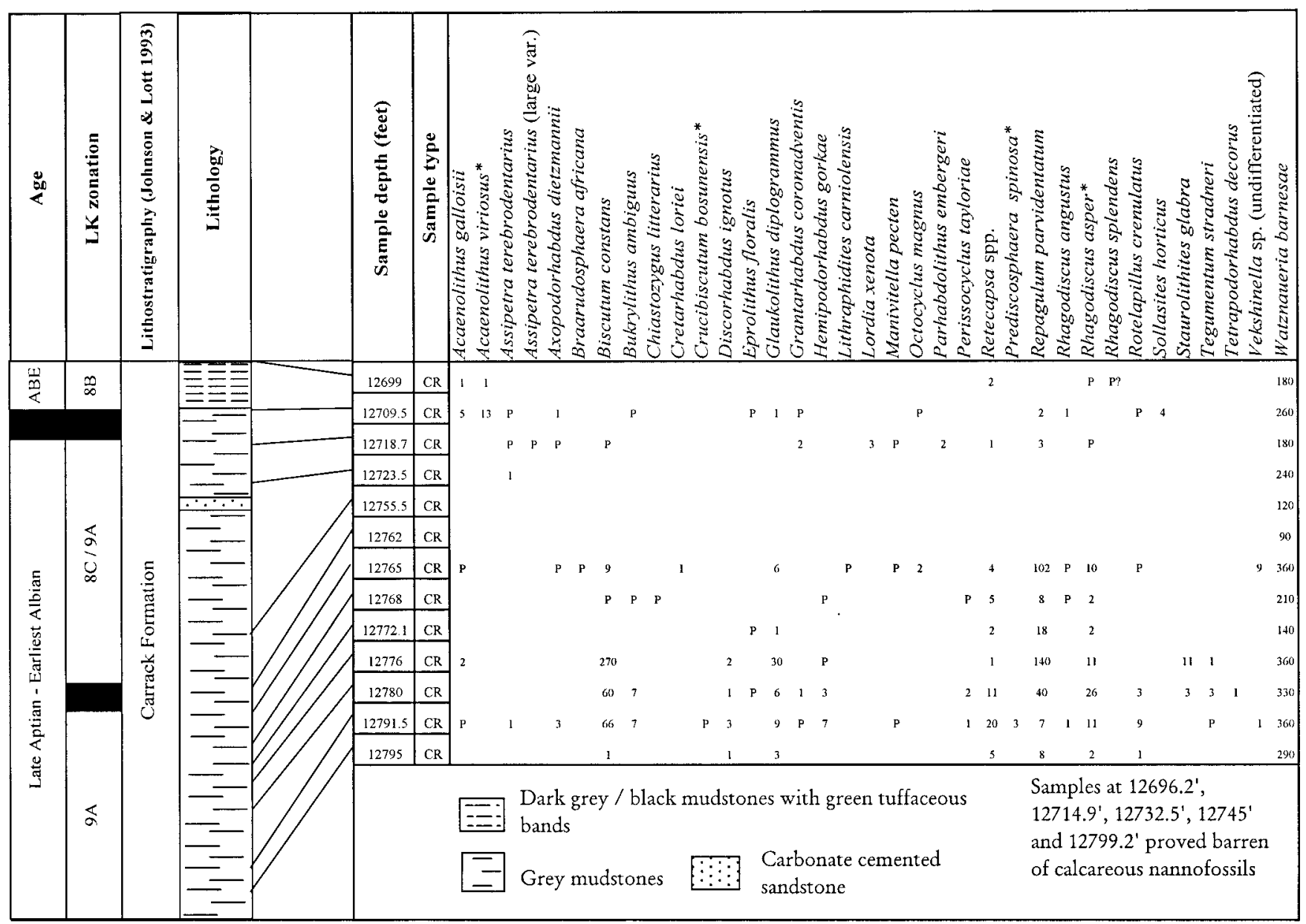

Fig. 10. Stratigraphical distribution of nannofossils from UK Moray Firth Well 15/28a-3. Note the low nannofossil diversity, a characteristic of the poorly calcareous Carrack Formation (Johnson \& Lott, 1993). Palynological evidence (FDO of Protoellipsodinium clavulum and common Dingodinium albertii) suggests penetration of uppermost Aptian strata from 12762core through to 12795core.

ammonite-dated sediments from the Speeton LA1 Beds of Mitchell \& Underwood (1999). The consistent FDO of the Assipetra infracretaceal A. terebrodentarius group and an isolated incursion of Micrantholithus hoschulzii are recorded from Subzone LK8B in the Moray Firth (identified from core and ditch-cuttings data). Acaenolithus viriosus was recorded as low as the top of schrammeni Subzonal ammonite-dated sediments from the Kirchrode II borehole, Germany (Jakubowski, pers. comm., 1999) but is absent from basal schrammeni Subzonal strata from Vöhrum, Germany (Jeremiah, 1996 and Bown, pers. comm.). A FAD for A. viriosus within the basal Albian is supported by Kennedy et al. (2000) based on outcrop work from southern France. At the Col de Pré-Guittard section A. viriosus was found to range into sediments as least as old as the tardefurcata Zone (acuticostata Subzone equivalent). Its FAD was above the highest recorded Aptian jacobi Zonal ammonites.

Nannofossil recovery rapidly diminishes downhole within this subzone throughout the North Sea Basin (top Carrack Formation of Johnson \& Lott, 1993).

\section{Subzone LK8C}

Top: FAD of Acaenolithus viriosus [Jeremiah, 1996].

Base: LAD of abundant Rhagodiscus asper [Jakubowski, 1987]. Age: Early Albian (lower tardefurcata MF Zone, schrammeni MF Subzone).

Remarks: LK8C is rarely recognized due to the predominance of non-calcareous lithologies in the North Sea Basin. This subzone has been identified from the North Sea (Jeremiah, 1996 and this study, Fig. 10) and schrammeni Subzonal ammonite-dated strata at Vöhrum, onshore Germany (Jeremiah, 1996 and Bown, pers. comm.).

\section{Rhagodiscus asper Zone - LK9}

Top: LAD of abundant Rhagodiscus asper [Jakubowski, 1987]. Base: LAD of occasional/abundant Crucibiscutum bosunensis [this study].

Age: earliest Albian/Late Aptian (lowermost tardefurcata, schrammeni MF Subzone/jacobi MF Zone).

Remarks: LK9 has been subdivided into two subzones. Calcareous nannofossil recovery within Zone LK9 is poor throughout 


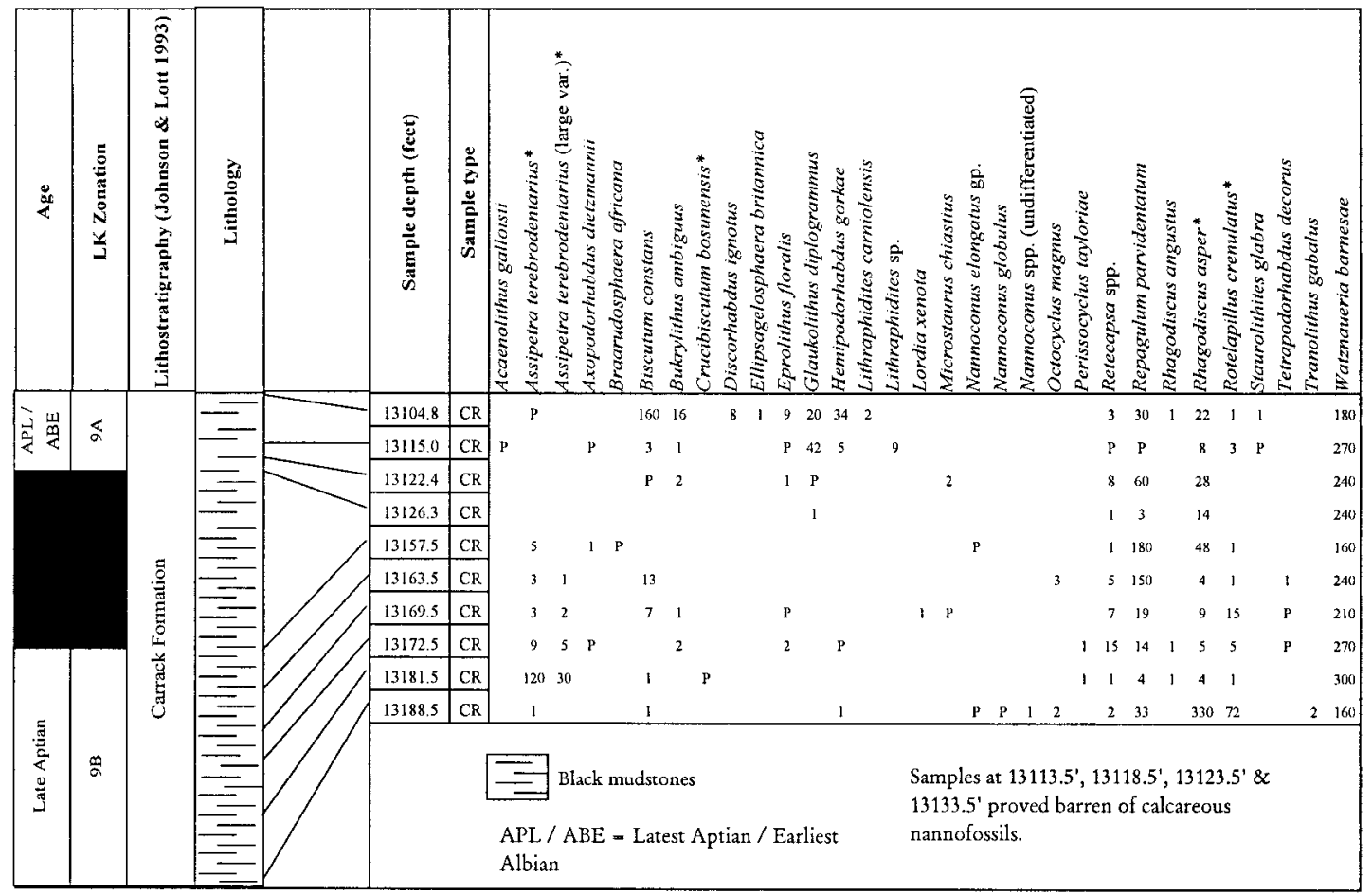

Fig. 11. Stratigraphical distribution of nannofossils from UK Moray Firth Well 15/30-9. Note the low nannofossil diversity, a characteristic of the poorly calcareous Carrack Formation (Johnson \& Lott, 1993). The increase in calcareous content with the associated LK9B nannofossil assemblage appears characteristic of the Moray Firth area. Equivalent sediments are generally barren of nannofossils further south in the Central Graben.

the North Sea Basin due to the predominantly non-calcareous nature of the lithologies. Selective sampling of calcareous sediments is required in order to recognize this zone (Figs 10-11). Nannofloral recovery increases rapidly at the top of Zone LK10 (Fig. 12). Zone LK9 was recorded from basal schrammeni and upper jacobi ammonite-dated samples from Vöhrum (Jeremiah, 1996). LK9-dated sediments from the Moray Firth also yield the FDO of the palynomorph Ovoidinium incomptum, a form which has a documented LAD in the jacobi Zone (Duxbury, 1983).

\section{Subzone LK9A}

Top: LAD of abundant Rhagodiscus asper [Jakubowski, 1987]. Base: LAD of common Assipetra terebrodentarius/infracretacea group [this study].

Age: earliest Albian/Late Aptian (lowermost tardefurcata Zone, schrammeni MF Subzone to jacobi MF Zone).

Remarks: Abundant $R$. asper are found sporadically throughout the Middle/Late Albian. It is, however, only in LK9A and older sediments that $R$. asper is a major component of assemblages. At Vöhrum (Jeremiah, 1996) $R$. asper makes up between 15\% and $30 \%$ of the total nannoflora when Watznaueria barnesae is discounted. It must be emphasized that sediments within this subzone, in the North Sea area, are generally non-calcareous. This has led to a depressed recording of the FDO of abundant $R$. asper in the literature (Bown et al., 1998).

\section{Subzone LK9B}

Top: LAD of common of Assipetra terebrodentarius/ infracretacea group [this study].
Base: LAD of occasional/abundant Crucibiscutum bosunensis [this study].

Age: Late Aptian (earliest jacobi MF Zone).

Remarks: a large variety of $A$. terebrodentarius is found at this level together with the FDO of rare, sporadic Crucibiscutum bosunensis (Fig. 11). This association has been recorded from the Outer Moray Firth in this study. Towards the base of the $A$. terebrodentarius quantitative acme, a short-lived correlative event yielding the influx of Rotelapillus crenulatus is recorded from throughout the Moray Firth. R. crenulatus, at this level, makes up some $15-20 \%$ of the nannoflora when Watznaueria barnesae is discounted (Fig. 11). Braarudosphaera batilliformis (Fig. 12) has an extremely restricted stratigraphic range within the base of LK9B where it is associated with Braarudosphaera africana and B. aff. B. stenorhetha in the Outer Moray Firth and southern North Sea basins.

\section{Crucibiscutum bosunensis Zone - LK10}

Top: LAD of common Crucibiscutum bosunensis [this study]. Base: LAD of common Lithraphidites moray-firthensis [this study].

Age: Late Aptian (nutfieldiensis MF Zone).

Remarks: calcareous content of Upper Aptian sediments in the North Sea Basin increases at and below Zone LK10 (Fig. 12). The delayed consistent FDOs of abundant Rhagodiscus asper are often recorded together with common Crucibiscutum bosunensis (Crucibiscutum cf. C. salebrosum of Bown et al., 1998). It is probable that the top of this zone corresponds to the top of 


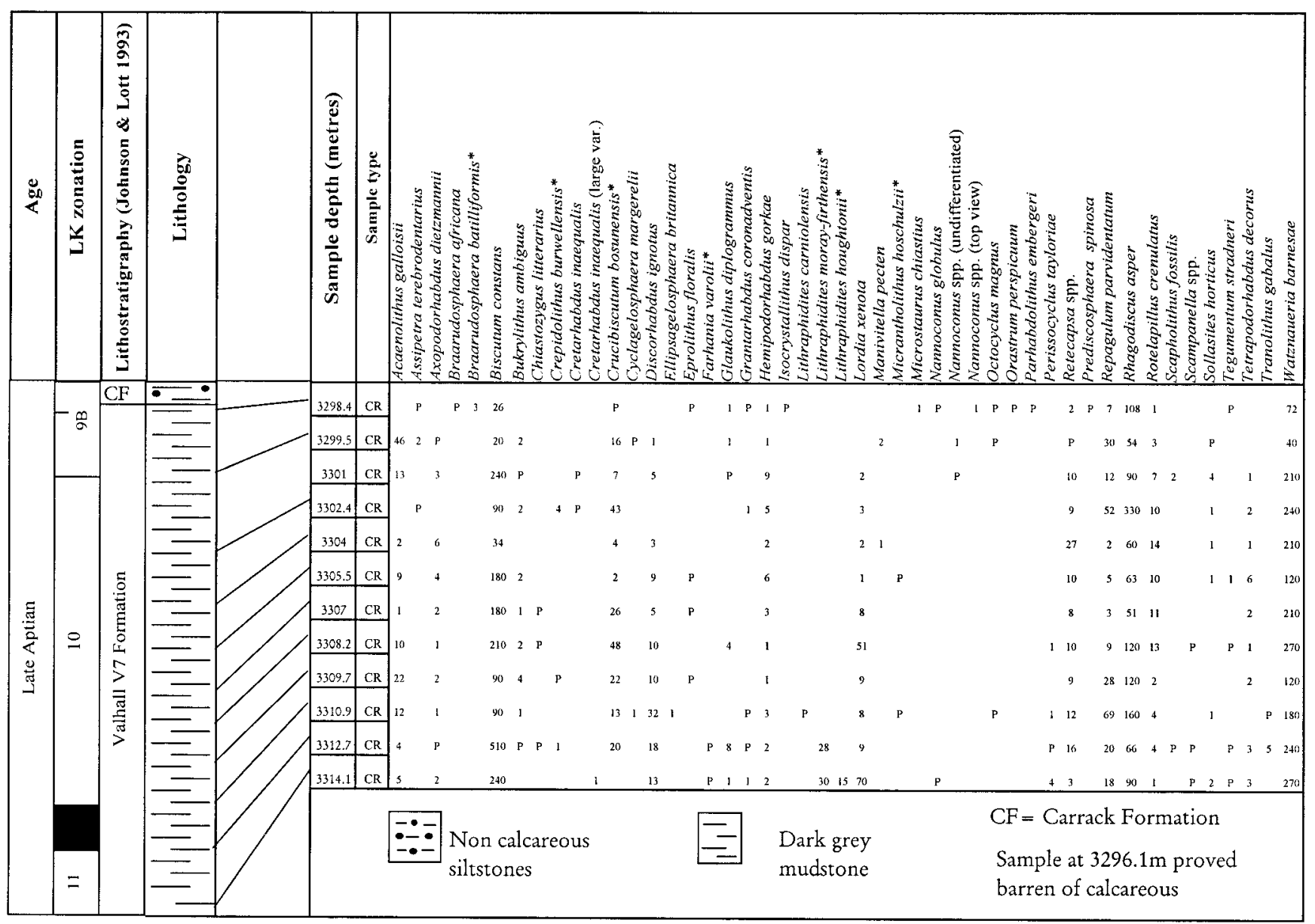

Fig. 12. Stratigraphical distribution of nannofossils from UK Moray Firth Well 21/1a-12. Note the rapid increase in abundance and diversity at the top of the Valhall Formation. Zone LK10 is not subdivided further in this well due to the absence of rare Lithraphidites moray-firthensis. In other nearby wells, however, rare occurrences of this form were present within LK10 and differentiation into LK10A and LK10B was possible. The Nannoconus globulus acme ( $N$. truittii event of Mutterlose, 1989) was also not encountered. Nearby wells have proven its occurrence within the upper part of LK10A.

Zone NLK8 of Jakubowski (1987) and the intra BC21 event of Bown et al. (1998). Nutfieldiensis ammonite-dated strata from Sarstedt (Saxony Basin, Germany) and Baulking Quarry, near Farringdon, UK, yield LK10 nannofossil assemblages. This zone can be subdivided into two subzones.

\section{Subzone LK10A}

Top: LAD of common Crucibiscutum bosunensis [this study]. Base: LAD of Lithraphidites moray-firthensis [Jakubowski, 1987].

Age: Late Aptian (nutfieldiensis MF Zone).

Remarks: LK10A yields the FDOs of sporadic Farhania varolii (see Appendix B) and downhole reappearance of sporadic Micrantholithus holschulzii (Fig. 12). Farhania varolii has not been utilized as a zonal marker as proposed by Bown et al. (1998) (Zone BC21) due to its inconsistent occurrence, the quantitative acmes of $F$. varolii within Zones LK11 and LK13 being far more reliable datums in the North Sea Basin.

The influx of Nannoconus globulus is an additional correlative event towards the top of the subzone. At Sarstedt, Germany this event occurs within nutfieldiensis ammonite-dated sediments. This is the first downhole, basin-wide nannoconid quantitative datum recorded in the North Sea Basin. This event probably equates to the $N$. truitti event of Mutterlose (1992) and the intra BC21 N. truitti/N. quadriangulus event of Bown et al. (1998). This boreal nannoconid event is extremely limited in its stratigraphical extent (note not encountered in well 21/1a-12, Fig. 12) and should not be automatically correlated to similar Late ?Aptian nannoconid influxes from the Tethyan realm (Erba, 1994; Cobianchi et al., 1999). This nannoconid correlation problem is specifically dealt with under the LK13B section. Other short-lived quantitative datums within LK10A include common Crepidolithus burwellensis (Fig. 12), common Tranolithus gabulus and abundant Cyclagelosphaera rotaclypeata. Acaenolithus galloisii is common throughout both LK10 and LK11.

\section{Subzone LK10B}

Top: LAD of Lithraphidites moray-firthensis [Jakubowski, 1987]. Base: LAD of common Lithraphidites moray-firthensis [this study]. 


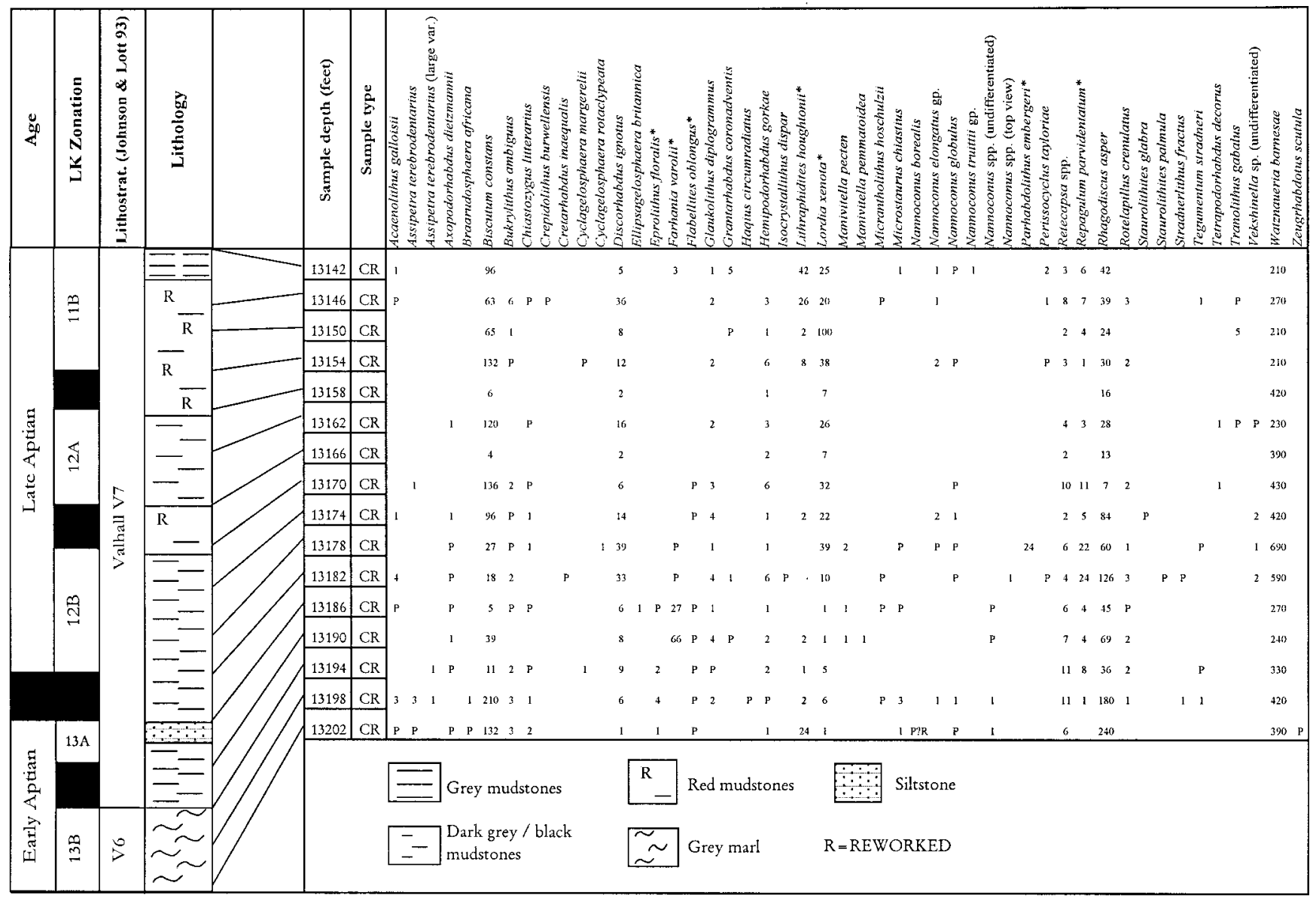

Fig. 13. Stratigraphical distribution of nannofossils from UK Moray Firth Well 15/28a-3.

Age: Late Aptian (nutfieldiensis MF Zone).

Remarks: in most ditch cuttings samples analysed from the North Sea Basin, LK10B is not identified, the underlying acme being far more reliable as a correlative marker. In the Outer Moray Firth, however, core evidence has confirmed a distinct separation of the FDO and its quantitative acme. The rarity and sporadic nature of L. moray-firthensis near its extinction datum has necessitated the downgrading of the nominate marker for top BC20 (Bown et al., 1998) to subzonal status in this zonation.

\section{Lithraphidites moray-firthensis Zone - LK11}

Top: LAD of common Lithraphidites moray-firthensis [this study].

Base: FAD of common Lithraphidites houghtonii [this study] and FAD of Lithraphidites moray-firthensis [this study].

Age: Late Aptian (martinioides MF Zone).

Remarks: This zone is wholly of Late Aptian age. Previous authors (Bown et al., 1998) have cautiously calibrated this event to the Early Aptian deshayesi Zone (Fig. 6). This zone has not been calibrated against ammonite-dated material although the age is constrained by nutfieldiensis ammonite-dated LK10 strata above and martinioides ammonite-dated LK11B sediments below. LK11 is subdivided into two subzones.

\section{Subzone LK11A}

Top: LAD of common Lithraphidites moray-firthensis [this study].

Base: FAD of common Lithraphidites moray-firthensis and LAD of common/abundant Farhania varolii [this study].

Age: Late Aptian (martinioides MF Zone).

Remarks: the FAD of common Crucibiscutum bosunensis occurs within this subzone and is a useful correlatable event in the Moray Firth and Central North Sea (Fig. 12). Further south, however, as in the West Heslerton II borehole (Appendix C) and Saxony Basin, this event ranges down into Zone LK12. The base of Subzone LK11A exhibits the younger of two quantitative increases of $F$. varolii (base of this event probably penetrated in 15/28a-3, fig. 13; 13142'core) in the North Sea Basin, the other defining the top of Zone LK13.

\section{Subzone LK11B}

Top: FAD of common Lithraphidites moray-firthensis and LAD of common/abundant Farhania varolii [this study].

Base: FAD of common Lithraphidites houghtonii and FAD of Lithraphidites moray-firthensis [this study].

Age: Late Aptian (martinioides MF Zone).

Remarks: in the Central North Sea and Outer Moray Firth red mudstones are characteristic of this subzone and the underlying 


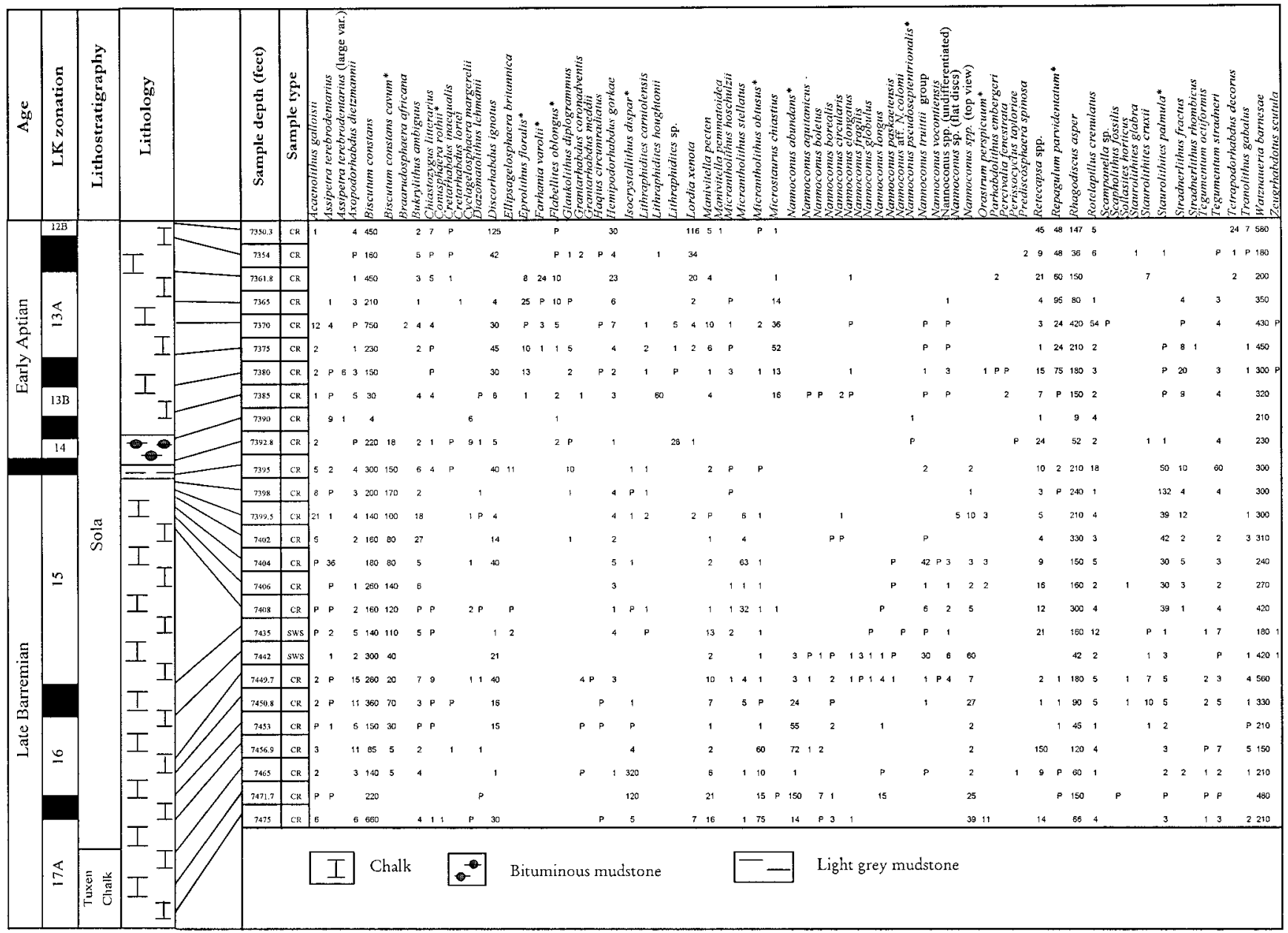

Fig. 14. Stratigraphical distribution of nannofossils from Danish Central Graben Well North-Jens 1. Note the presence of organic mudstones (Fischschiefer) and characteristic LK14 nannofossil assemblage in an otherwise chalk-dominated succession. The overlying Sola Formation (Ewadi Marl and Valhall V6 equivalent) yields a low abundance nannoconid assemblage, a feature typical of nannofloras north of the Southern North Sea area.

LK12 Zone (Fig. 13). The ammonite calibration of this subzone is confirmed by the presence of Tropaeum drewi (equivalent to the lower part of the martinioides Zone) in LK11B-dated strata from Rothenberg (Saxony Basin, Germany).

\section{Lordia xenota Zone - LK12}

Top: FAD of common Lithraphidites houghtonii [this study] and FAD of Lithraphidites moray-firthensis [this study].

Base: reappearance of common Farhania varolii [this study] and/or common Eprolithus floralis [this study].

Age: early Late Aptian to latest Early Aptian (martinioides to bowerbanki MF Zone).

Remarks: the FAD of Prediscosphaera spinosa (elliptical forms of Prediscosphaera with axial cross) appears to range into the latest Early Aptian. At Rothenberg (Saxony Basin, Germany), basal Late Aptian Tropaeum drewi ammonite-dated strata and topmost Early Aptian bowerbanki ammonite-dated samples at Gehrdener-Berg (Saxony Basin, Germany), were found to yield Zone LK12 nannofloras associated with P. spinosa. Prediscosphaera spinosa has also been observed in LK12-dated samples from the Danish North Sea (Fig. 14), West Netherlands Basin Well Spijkenisse-1 (51 $\left.50^{\circ} \mathrm{N} 04^{\circ} 19^{\prime} \mathrm{E}\right)$, associated with the LK12B $P$. embergeri influx, and at the West Heslerton II borehole (10.85 m). Prediscosphaera spinosa has, however, yet to be found below uppermost Aptian LK9 sediments within the UK Central North Sea and Moray Firth Sub-basin. Zone LK12 is subdivided into two subzones and is characterized by the abundant occurrence of Lordia xenota.

\section{Subzone LK12A}

Top: FAD of common/abundant Lithraphidites houghtonii [this study] and FAD of Lithraphidites moray-firthensis [this study].

Base: LAD of consistent Flabellites oblongus [this study].

Age: Late Aptian to latest Early Aptian (martinioides to bowerbanki MF Subzone).

Remarks: the base of the common/abundant Lithraphidites houghtonii quantitative event is recorded from intra $T$. drewi (martinioides Zone) ammonite-dated sediments at Rothenberg. Seribiscutum dentatum (large variety, 6-7 $\mu \mathrm{m}$ ) is restricted to this subzone. 


\section{Subzone LK12B}

Top: LAD of consistent Flabellites oblongus [this study].

Base: downhole reappearance of common Farhania varolii [this study] and/or common Eprolithus floralis [this study].

Age: latest Early Aptian (bowerbanki MF Zone).

Remarks: in the North Sea Basin the downhole appearance of $F$. oblongus is an important corelative datum (Fig. 13). This event has, however, proven unreliable from onshore sections where $F$. oblongus is identified from both LK10- and LK11-dated sediments. An influx of Parhabdolithus embergeri is encountered at the base of Subzone LK12B. Although short-lived it appears to be a basin-wide event having been recorded from the Moray Firth sub-basin (Fig. 13), onshore Germany and Netherlands.

\section{Eprolithus floralis Zone - LK13}

Top: downhole reappearance of common Farhania varolii [this study] and/or common Eprolithus floralis [this study].

Base: LAD of common Cyclagelosphaera margerelii [this study]. Age: Early Aptian (deshayesi/upper forbesi MF Zones).

Remarks: in the North Sea Basin and onshore at Speeton and the Skegness borehole (Mutterlose, 1989) this zone corresponds to a unit of limestones and marl, the Ewaldi Marl. LK13 is subdivided into the following subzones.

\section{Subzone LK13A}

Top: downhole reappearance of common Farhania varolii [this study] and/or common Eprolithus floralis [this study].

Base: FAD of Farhania varolii [Mutterlose, 1991].

Age: Early Aptian (late deshayesi MF Zone).

Remarks: this subzone has not been identified from ammonitebearing strata although its stratigraphic range is constrained by deshayesi ammonite-bearing LK13B sediments below and bowerbanki ammonite-dated LK12 sediments above. The FAD of Tetrapodorhabdus decorus occurs within this subzone (Fig. 14).

\section{Subzone LK13B}

Top: FAD of Farhania varolii [Mutterlose, 1991].

Base: LAD of common Cyclagelosphaera margerelii [this study]. Age: Early Aptian (early deshayesi to late forbesi MF Zones).

Remarks: the Tethyan marker, Hayesites irregularis, is confined to Zones LK13 and LK14 at southern England localities (Fig. 5). It has not been identified from any UK Central Graben section or at Speeton in this study. Its presence, however, has been confirmed from younger LK12 sediments in the West Netherlands Basin and Danish North Sea. Bischoff \& Mutterlose (1998), however, also indicated the presence of $H$. irregularis (Rucinolithus irregularis) within the Early Aptian of Central North Sea Well 15/30-3. The presence of H. irregularis could not be substantiated from this well (Jeremiah, 2000) or any surrounding well in the Moray Firth area.

Diazomatolithus lehmanii is present within this subzone (Figs 4 and 5) from onshore localities and is probably indicative of a Tethyan connection with the Boreal Realm that existed at this time. At the Heslerton II borehole (Appendix C) an abundant occurrence of $D$. lehmanii was recorded from the base of LK13B $(12.1 \mathrm{~m})$. Stradnerlithus fractus, a form which is generally rare from the Boreal Lower Cretaceous is also common at levels within this subzone (Figs 4, 14).
Lithraphidites spp., including $L$. houghtonii are abundant in the lower part of this subzone associated with Assipetra terebrodentarius (large variety, $8-12 \mu \mathrm{m}$ ). The various forms of Lithraphidites spp. present at this level may have led to the misconception that L. moray-firthensis is restricted to the Early Aptian. The FAD of common Repagulum parvidentatum is at the base of LK13B (Figs 4, 5 and 14).

Lower Aptian LK13 'ewaldi Marl' (Valhall V6 of Johnson \& Lott, 1993) sediments from the Vlieland Basin and Friesland Platform (northern onshore Netherlands) yield an influx of nannoconids including $N$. truittii, $N$. globulus and $N$. vocontiensis. An increase of nannoconids at this level is also recognized from Speeton (Fig. 4), the Skegness borehole (Mutterlose, 1989) and the Heslerton II borehole (Appendix C) but does not appear present further north in the Danish North Sea and UK Central Graben. A similar increase in wide canal nannoconids is noted in the Tethyan Realm above the Lower Aptian 'nannoconid crisis' (Erba, 1994) but has been correlated to a very short-lived, endemic Boreal Upper Aptian event, the $N$. truitti event of Mutterlose (1992), by Erba (1994) and Cobianchi et al. (1999).

The ammonite calibration of this subzone is confirmed by the presence of forbesi and deshayesi ammonites at Speeton (Fig. 4). This age of this zone is also confirmed in the RC1544 borehole by the presence of LK13B nannofossil assemblages from the Lower Hythe Beds (Fig. 5). These strata throughout southern England are associated with deshayesi zonal ammonites (Ruffell, 1992).

\section{Nannoconus pseudoseptentrionalis Zone - LK14}

Top: LAD of common Cyclagelosphaera margerelii [this study]. Base: LAD of an influx of Biscutum constans cavum [this study] and/or common Staurolithites palmula [this study].

Age: Early Aptian (early forbesi to fissicostatus MF Zones)

Remarks: this zone is subdivided into two subzones based upon the FAD of Eprolithus floralis. In the Central North Sea LK14 correlates with organic, laminated mudstones commonly known as the 'Base Aptian Shale' or Fischschiefer. Onshore in England and the West Netherlands Basin, however, facies changes do not allow the organic mudstones of the offshore realm to be so easily recognized. The Fischschiefer in the North Sea Basin correlates with the Fischschiefer and Bodei clays of the classic German sections (Appendix B).

The base of LK14 marks a major change in the nannofossil composition. Nannofossils typical of the Tethyan Late Barremian migrate into the Boreal Realm for the first time. These forms include Flabellites oblongus, Hayesites irregularis and Assipetra terebrodentarius (large variety). Conusphaera rothii, which is recorded from the earliest Aptian of Tethys (LAD within the weissi MF Zone) has, however, not been recorded from the earliest Aptian of the North Sea Basin or southern England. This apparent anomaly may, however, be more a result of the poor ammonite correlation between the Boreal and Tethyan Realm over the Aptian/Barremian boundary rather than $C$. rothii exhibiting endemism.

There appears to be gathering evidence from nannofossil data that the Fischschiefer is equivalent to other anoxic shales recorded from Tethyan sections (see below). It is possible that the base of the Aptian in the Boreal Realm (taken at the base of 
fissicostatus ammonite-dated clays) correlates to the base of the Tethyan anoxic mudstones. This therefore leaves an interval of lowermost Aptian tuarkyricus and weissi Tethyan ammonite zonal sediments below the anoxic shales as correlating to an interval of Boreal, bidentatum ammonite-dated, latest Barremian. This suggestion is supported by the following observations.

1. The base of the Aptian marks a major change in the nannofloral composition of the North Sea Basin. Nannofossils typical of the Tethyan Late Barremian migrate into the Boreal Realm for the first time and have consistent FADs at the base of Aptian fissicostatus ammonite-bearing sediments. These forms include Flabellites oblongus, Hayesites irregularis, influxes of Cyclagelosphaera margerelii and Assipetra terebrodentarius (large variety) associated with a low-diversity nannoconid suite. All these nannofossil elements are also characteristic of Early Aptian Tethyan anoxic shales. Uppermost Barremian bidentatum ammonite-bearing sediments in the North Sea Basin yield a Boreal-restricted assemblage, very different to that recorded from the Tethyan localities (see Zone LK13 discussion). This indicates very little communication between the southern European Tethys area and the North Sea Basin during the latest Barremian.

2. The termination of these anoxic OAE1a (Arthur et al., 1990) shales occurred at the same time in both the North Sea Basin and in Tethys. The reappearance of nannoconids associated with the FAD of $E$. floralis is recorded from both areas.

3. Conusphaera rothii, a nannofossil typical of earliest Aptian tuarkyricus and weissi Tethyan ammonite zonal sediments has a LAD before the inception of the OAEla anoxic event (Rio Argos section, Caracava, SE Spain (Hoedemaeker \& Leereveld, 1995). Conusphaera rothii is also absent from the equivalent North Sea Fischschiefer facies.

The apparent calibration problem between the base Aptian of the North Sea and Tethys can perhaps be explained by the earlier evolution of Prodeshayesites in the southern European Tethyan Realm. An endemic Boreal nannofossil and heteromorph ammonite suite persisted in the North Sea Basin until the Lower Aptian sea level rise, OAE1a (Arthur et al., 1990), and the resultant introduction of a Tethyan micro- and macrofaunal element with its associated organic mudstone lithologies. This idea contrasts markedly with the current views on Boreal/Tethyan correlations and more detailed ammonite and nannofossil work from Tethyan localities is required to support this theory.

\section{Subzone LK14A}

Top: LAD of common/abundant Cyclagelosphaera margerelii [this study].

Base: FAD of Eprolithus floralis [Taylor, 1982].

Age: Early Aptian (lower forbesi MF Zone).

Remarks: this subzone is rarely recognized in routine analyses but has been positively identified in core from the topmost Fischschiefer (unreleased well, Central North Sea), forbesi ammonite-dated material at Speeton (Bed LA6, Fig. 4) and the Atherfield Clay (Fig. 5).

The FAD of Eprolithus floralis is an extremely useful cosmopolitan datum. Unfortunately the widespread use of the inception of $E$. floralis as marking the base of the Tethyan Late Aptian (base criteria for the Late Aptian Parhabdolithus angustus Zone of Thierstein, 1973) (Erba, 1994; Cobianchi et al., 1999) has led to confusion in correlations of Boreal and Tethyan sections. Samples analysed by the author from the Rio Argos section, Caracava, SE Spain (Hoedemaeker \& Leereveld, 1995) confirmed the FAD of E. floralis immediately above black mudstones attributed to the global oceanic anoxic event OAE 1a (Arthur et al., 1990). The same sequence of events is recorded from the Selli Level of Italy (Cobianchi et al., 1999), the Middle Almadich Member of SE Spain (Aguado et al., 1999) and the Fischschiefer of the North Sea. The presence of E. floralis immediately above the so-called 'nannoconid crisis' (Erba, 1994) is therefore a common event worldwide. The FAD of E. floralis immediately above these anoxic levels thus indicates that the Selli Level, Middle Almadich Member and other so-called early Aptian OAE 1a mudstones are no younger than the earliest Aptian intra-forbesi Zone. No evidence of an unconformity at the Lower to Upper Aptian boundary is cited from Tethyan localities (Erba, 1994; Cobianchi et al., 1999). It is therefore considered probable that the so-called 'Upper Aptian' sediments immediately above the anoxic event at those Tethyan localities are still of Early Aptian age.

\section{Subzone LK14B}

Top: FAD of Eprolithus floralis [Taylor, 1982].

Base: LAD of influx of Biscutum constans cavum [this study] and/or common Staurolithites palmula [this study].

Age: Early Aptian (lower forbesi to fissicostatus MF Zones).

Remarks: this subzone constitutes the majority of the Fischschiefer facies in the North Sea Basin. Nannoconus pseudoseptentrionalis, a potential ancestor of Eprolithus floralis is characteristic of this subzone in England and over much of the North Sea. In the northern North Sea (e.g. Norwegian well 31/3-3), extremely rare occurrences of both Flabellites oblongus and $N$. pseudoseptentrionalis have been recorded from below the Fischschiefer within the latest Barremian. Nannoconus pseudoseptentrionalis also has a short-lived incursion within the Lower Barremian anoxic Hauptblatterton facies of the southern North Sea and Saxony Basin. Large forms of Assipetra terebrodentarius are common at levels within the Fischschiefer as they are in Tethyan sediments of equivalent age (Aguado et al., 1999)

In the southern England sections studied, common Ellipsagelosphaera britannica are also recorded (Fig. 5 and Appendix B), a result of Upper Jurassic reworking which is prevalent in the area. The high relative abundances of E. britannica documented from the Atherfield Clay on the Isle of Wight (Bown et al., 1998) are probably accentuated by similar Upper Jurassic reworking. Modern day estuarine nannofossil assemblages from the nearby Solent yield over $30 \%$ of Jurassic forms, again dominated by $E$. britannica. An Early Aptian E. britannica event is not recorded from Speeton, the Heslerton II borehole, the North Sea Basin or onshore Netherlands.

This subzone has been found to yield basal Aptian fissicostatus ammonites at Speeton (Fig. 4), the basal Aptian ammonite, Prodeshayesites bodei from Alstatte in the 'bodei' clays (Saxony Basin, Germany) and slightly younger forbesi ammonites in the Atherfield Clay. 


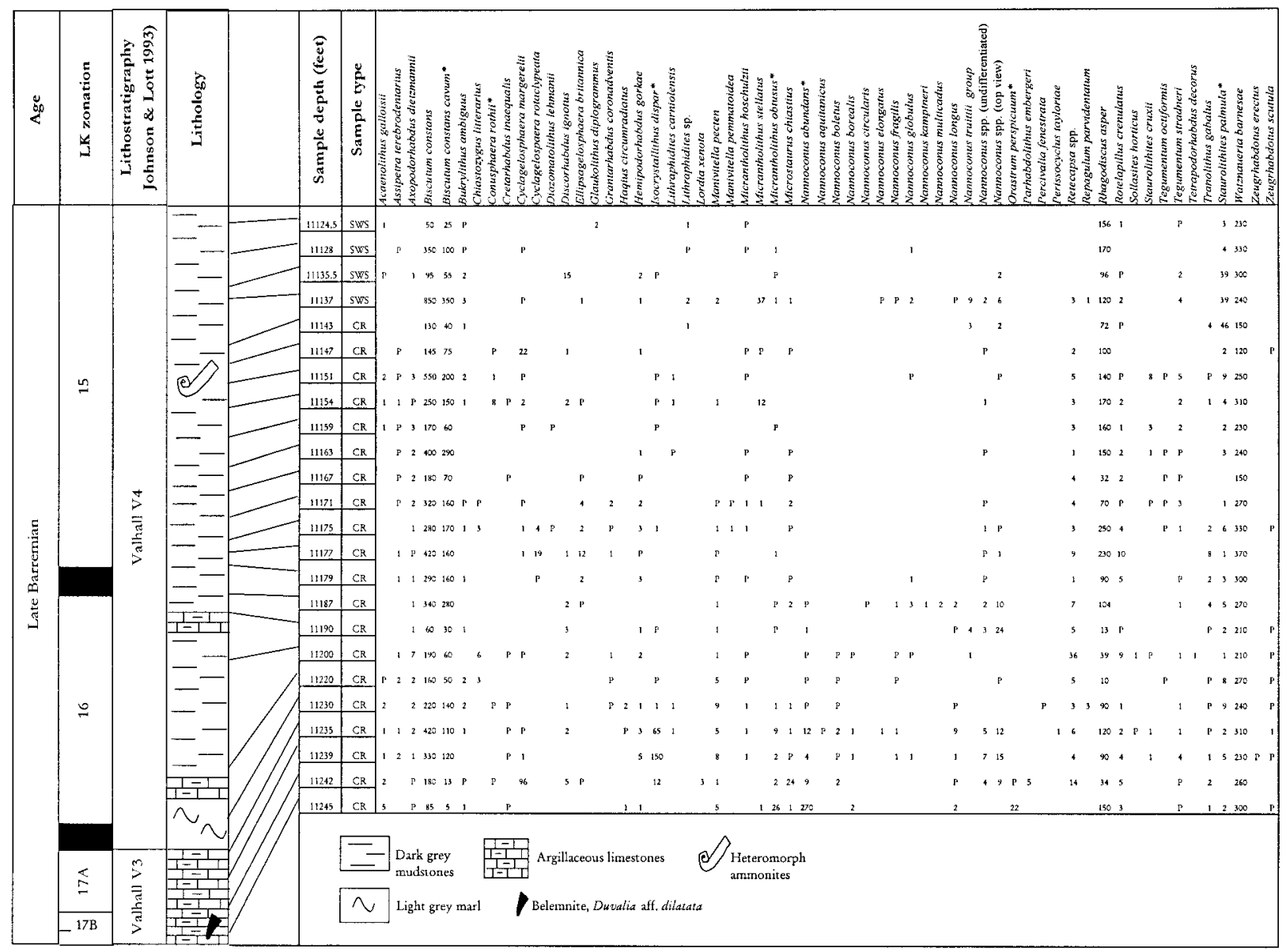

Fig. 15. Stratigraphical distribution of nannofossils from UK Central Graben Well 22/26a-2.

\section{Staurolithites palmula Zone - LK15}

Top: LAD of influx of Biscutum constans cavum [this study] and/or common Staurolithites palmula [this study].

Base: LAD of Nannoconus abundans [Taylor, 1982].

Age: Late Barremian (bidentatum to ?pingue MF Zones).

Remarks: Bidentatum ammonite-bearing strata from the top of the Late Barremian at Speeton are found to yield an LK15 endemic Boreal nannofossil association. Short-lived warm water incursions are recorded (probably via the proto-Atlantic) but, in general, the nannofloral assemblages cannot be directly correlated with Tethyan sections over much of the Late Barremian. Tethyan incursions are recorded from the upper part of LK15, one of which is characterized by a short-lived influx of Micrantholithus stellatus (Fig. 15), a form common throughout the latest Barremian of southern Spain (Aguado et al., 1997). A brief incursion of Conusphara rothii is recorded from a narrow horizon (Figs 15 and 16) within the Upper Barremian of the North Sea Basin. This event is also noted by Gallagher in Bown et al. (1998) (C. cf. C. rothii, squat morphology) but was considered a Lower Aptian 'bodei' Clay equivalent event. This nannofloral event has, however, been recorded with Upper Barremian heteromorph ammonites Hemihoplites, Camereiceras and Heteroceras sp. in Central North Sea Well 22/26a-2 (Fig. 15). This ammonite assemblage is more indicative of the
Tethyan feraudinianus MF Zone (equates to the Boreal stolleyi MF Zone; P. Rawson, pers. comm.) and, together with the associated $C$. rothii, is good evidence for a warm-water incursion into the Boreal Realm during stolleyi times. Diazomatolithus lehmanii and Isocrystallithus dispar, forms characteristic of the Tethyan Late Barremian, occur sporadically throughout LK15 (Figs 14 and 15).

Thin organic horizons very similar in lithology to the overlying Fischschiefer are also developed yielding abundant Cyclagelosphaera margerelii (Figs 15 and 16). Unlike the Fischschiefer, however, influxes of large Ellipsagelosphaera britannica and common Cyclagelosphaera rotaclypeata are also recorded (Fig. 15). The E. britannica influx was also documented by Gallagher in Bown et al. (1998) but was considered an Early Aptian event. The conspicuous large B. constans event of Gallagher in Bown et al. (1998) probably equates to the top $B$. constans cavum influx in this study. Tegumentum octiformis has its LAD towards the top of LK15.

\section{Nannoconus abundans Zone - LK16}

Top: LAD of Nannoconus abundans [Taylor, 1982].

Base: LAD of common Isocrystallithus dispar [this study].

Age: Late Barremian (?pingue MF Zone). 


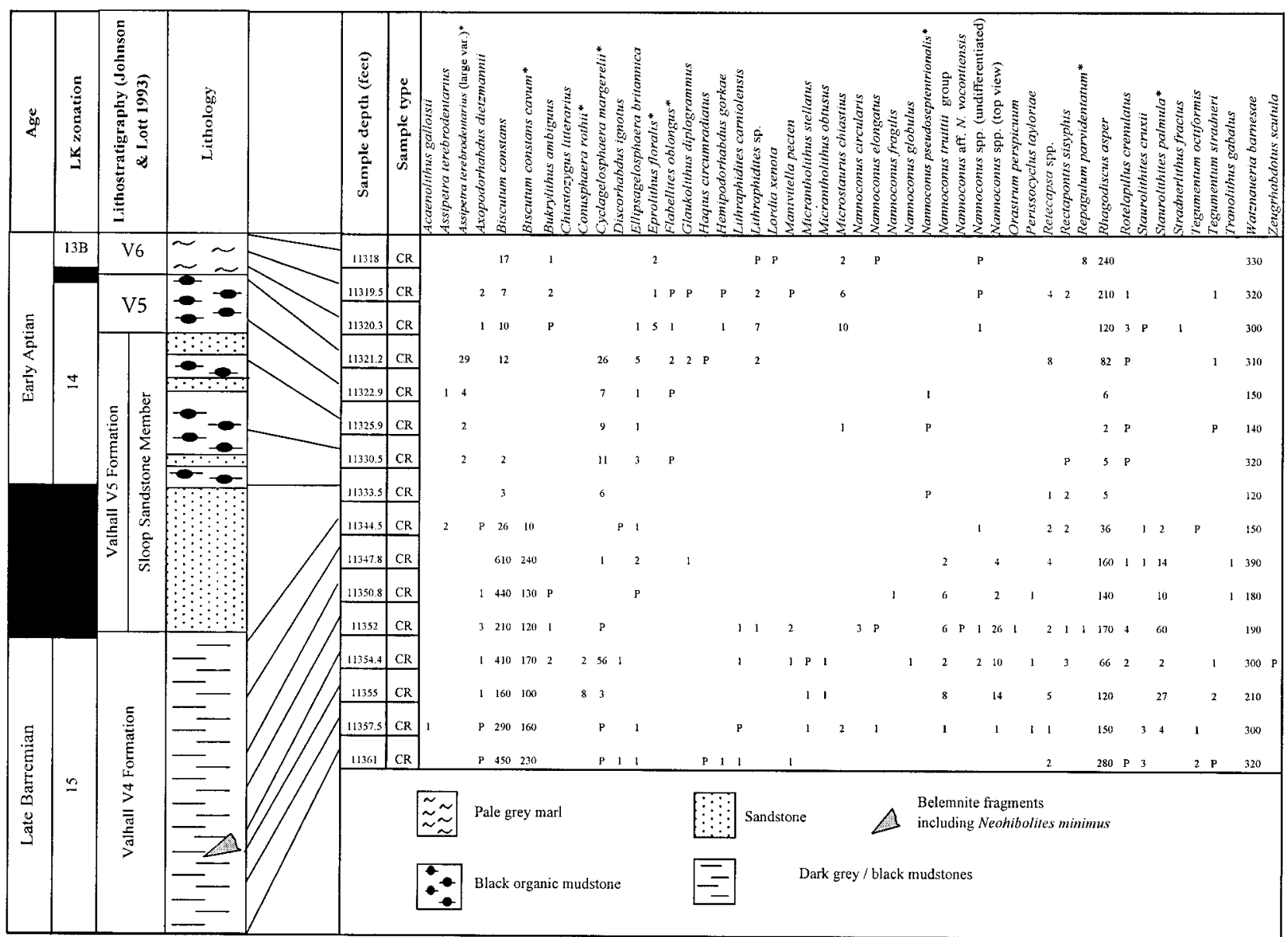

Fig. 16. Stratigraphical distribution of nannofossils from UK Moray Firth Well 21/2-6.

Remarks: the top of this zone marks a major downhole change in nannofossil composition in the Central and Southern North Sea. A diverse, Boreal endemic nannoconid assemblage including $N$. abundans, $N$. borealis, $N$. boletus and $N$. longus all have their consistent LADs at this level (Figs 14 and 15). LK16 differentiation is, however, complicated in the Northern North Sea (Fig. 17) by the extremely rare occurrence of $N$. abundans above LK17. Its extreme rarity usually precludes LK16 from being identified as a definitive zone in this area. Bown et al. (1998) record the LAD of $N$. abundans within the Early Aptian of the Heslerton II borehole (depth not quoted). This isolated record may be a result of reworking since this occurrence could not be substantiated in this study (Appendix C). Gallagher in Bown et al. (1998), by contrast, indicated the FDO of $N$. abundans below both the $C$. rothii incursion and Ellipsagelosphaera britannica influx. This sequence of events is supported in the present study. The age attributed to these events and calibration with the ammonite zonation is, however, markedly different.

Nannoconus borealis is not utilized as a zonal marker in this study due to its sporadic occurrence over the majority of its range. Bown et al. (1998) used both the FAD and LAD of $N$. borealis as zonal markers. In this study the highest consistent LAD is associated with the overall downhole increase in nanno- conid diversity at the top of Zone LK16 (Figs 14 and 15). The consistent LAD of $N$. borealis is utilized as supportive evidence for top Zone LK16 but the associated presence of $N$. abundans is considered a more reliable nannofossil datum in the North Sea Basin. Nannoconus borealis was absent from the West Heslerton II borehole and extremely rare in the northern North Sea and onshore Netherlands.

Additional correlative events include the downhole reappearance of Conusphaera rothii associated with the FDO of common $N$. abundans towards the base of this zone (also documented by Gallagher in Bown et al., 1998).

\section{Micrantholithus obtusus Zone - LK17}

Top: LAD of common Isocrystallithus dispar [this study]. Base: LAD of common Zeugrhabdotus scutula [Bown et al., 1998].

Age: Late Barremian (?pingue MF Zone).

Remarks: LK17 is subdivided into two subzones.

\section{Subzone LK17A}

Top: LAD of common Isocrystallithus dispar [this study]. Base: FAD of common Isocrystallithus dispar [this study]. Age: Late Barremian (?pingue MF Zone). 


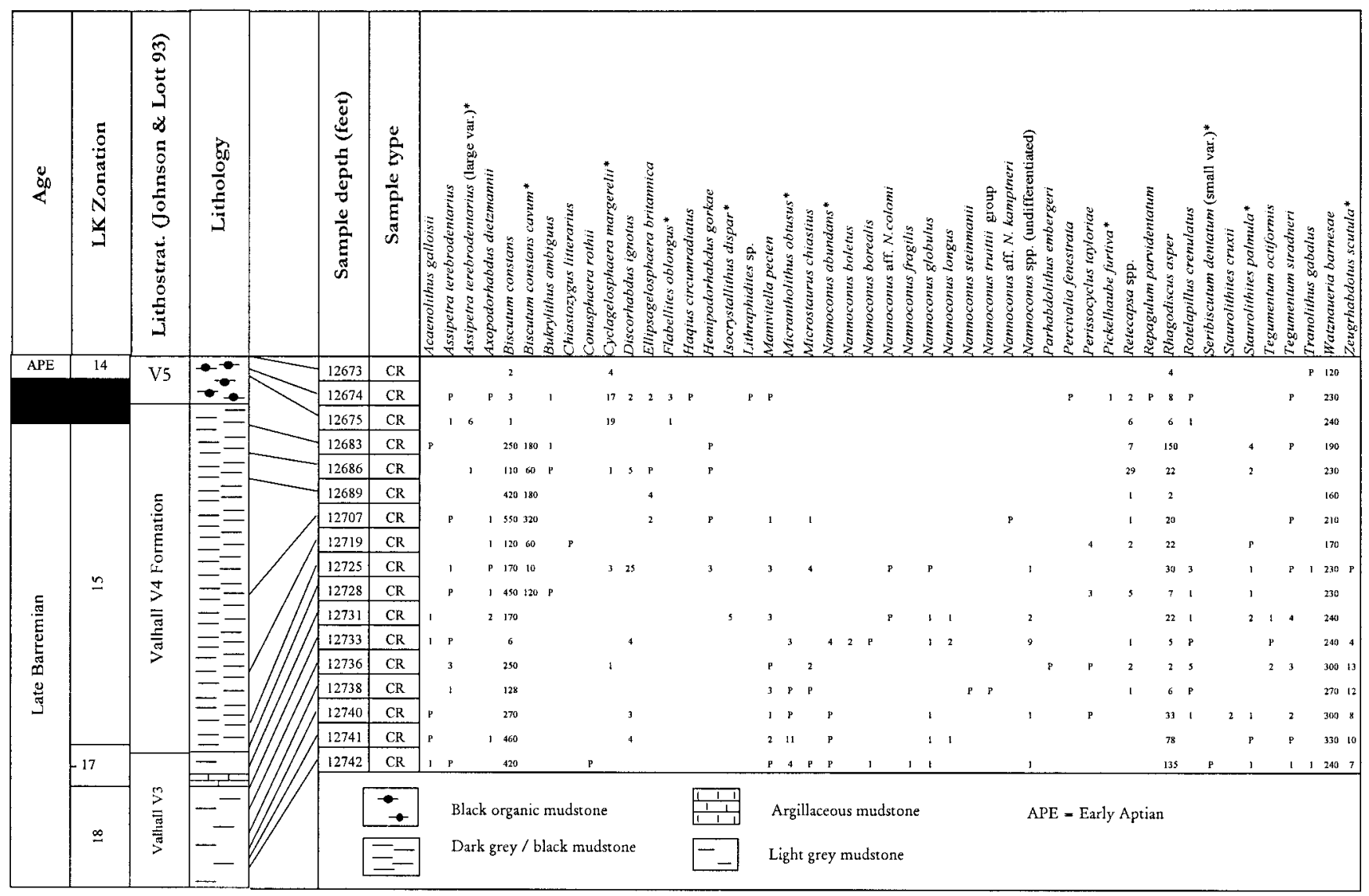

Fig. 17. Stratigraphical distribution of nannofossils from UK Viking Graben Well 3/18c-1. Note the low abundance and diversity of nannoconids within LK17 and LK18 compared to equivalent sections from the Moray Firth and Central Graben wells.

Remarks: Isocrystallithus dispar is recorded throughout the Albian to Barremian of Tethys (Rawson \& Jeremiah, 2001) but is rare in the North Sea Basin. The LK17A incursion is an exception. This short-lived quantitative acme of Isocrystallithus dispar has been recorded in core from Central North Sea well 22/26a-2 (Fig. 15) with a Tethyan indicator belemnite, Duvalia aff. robusta, which supports a warm-water connection with the North Sea Basin at this time probably via a proto-Atlantic route (Rawson \& Jeremiah, 2001). Additional correlative events include an incursion of Orastrum perspicuum at the base of this subzone (Fig. 15). The FDO occurrence of common Micrantholithus obtusus approximates to this subzone (Figs 14 and 15). The $I$. dispar acme event has been identified as far south as the offshore Netherlands L Block (Vlieland Basin) but has yet to be recorded from the Saxony Basin.

\section{Subzone LK17B}

Top: FAD of common Isocrystallithus dispar [this study].

Base: LAD of common Zeugrhabdotus scutula [Bown et al., 1998].

Age: Late Barremian (?denkmanni MF Zone).

Remarks: The nannofloral assemblage is characterized by a diverse nannoconid assemblage dominated by $N$. abundans, $N$. longus, $N$. boletus and $N$. bucheri group.

\section{Zeugrhabdotus scutula Zone - LK18}

Top: LAD of common Zeugrhabdotus scutula [Bown et al., 1998].

Base: LAD of consistent Diazomatolithus lehmanii [this study].

Age: Late Barremian (?denckmanni MF Zones).

Comments: the FDO of Crucibiscutum salebrosum (large variety, Crux, 1989) is towards the base of LK18 (Fig. 18).

\section{Diazomatolithus lehmanii Zone - LK19}

Top: LAD of consistent Diazomatolithus lehmanii [this study]. Base: LAD of short-lived acme of Cyclagelosphaera margerelii [this study].

Age: Early Barremian (elegans MF Zone).

Comments: the identification of LK19 based solely on the presence of $D$. lehmanii should be used with extreme caution. Sporadic occurrences of $D$. lehmanii are recorded throughout the Late Barremian of the North Sea Basin. Further south in southern Britain, with increased Tethyan influence, D. lehmanii is recorded consistently in Lower Aptian strata. Identification of the associated Zeugrhabdotus scutula acme is essential, preferably with one of the following short-lived quantitative datums documented below which can be correlated throughout the Outer Moray Firth, Central North Sea and Tuxen Formation of 


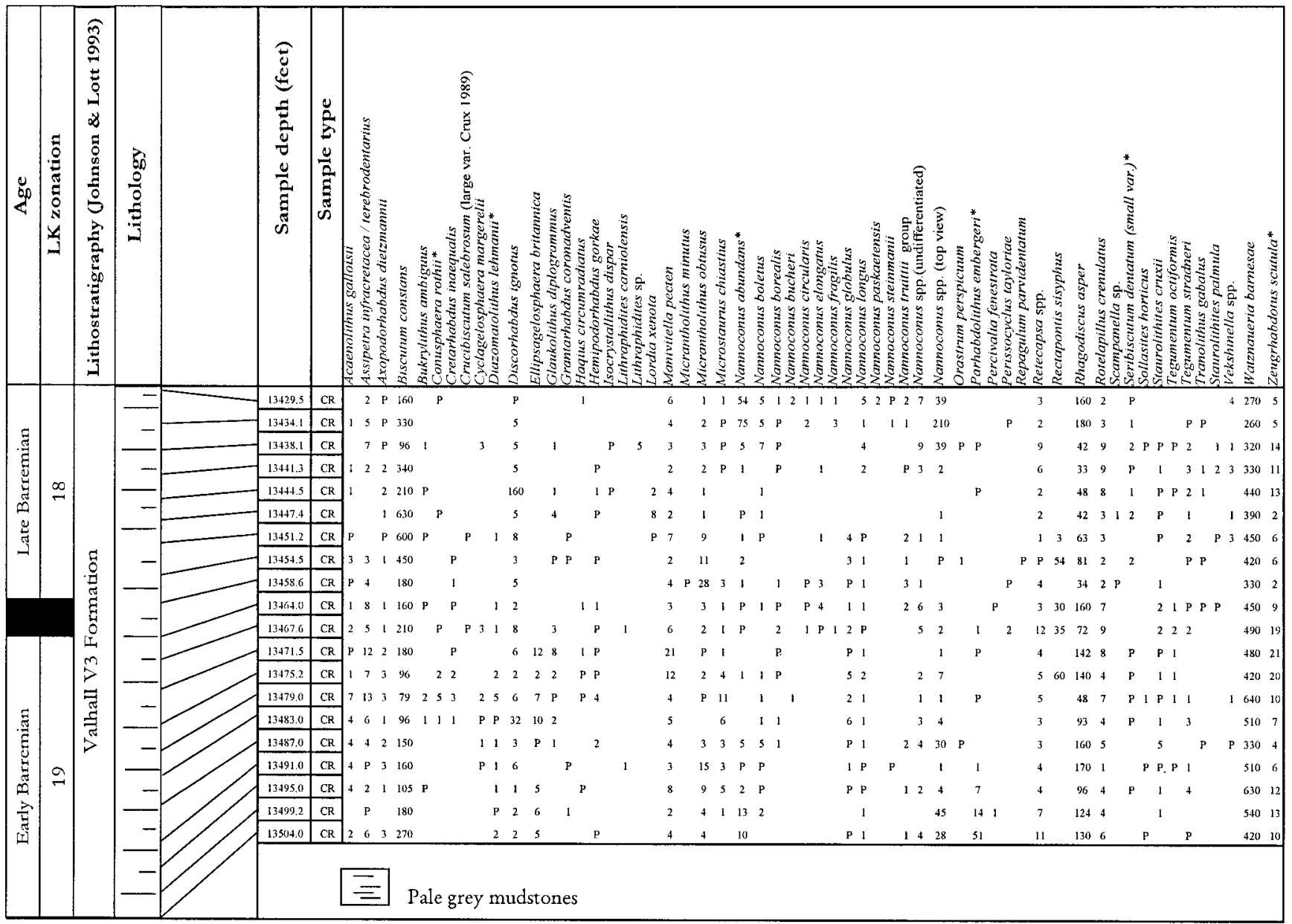

Fig. 18. Stratigraphical distribution of nannofossils from UK Moray Firth Well 15/29a-5.

the Danish North Sea. These events in descending order are as follows:

i. incursion of common Parhabdolithus embergeri (Figs 18 and 19);

ii. incursion of common Sollasites horticus (Fig. 19). The FAD of Acaenolithus galloisii (Acaenolithus sp. 1 of Bown et al., 1998) lies within LK19 associated with the Sollasites horticus incursion (Fig. 19);

iii. incursion of common Percivalia fenestrata (Fig. 19).

In the Netherlands onshore sections investigated the LAD of consistent D. lehmanii appears depressed. Here, the LAD of consistent $D$. lehmanii (common at this level) is found immediately prior to the onset of the Hauptblatterton facies (top Subzone LK20C).

\section{Conusphaera rothii Zone - LK20}

Top: LAD of short-lived acme of Cyclagelosphaera margerelii [this study].

Base: LAD of Clepsilithus maculosus [Crux, 1989].

Age: Early Barremian (lower elegans/upper variabilis $\mathrm{MF}$ Zones).
Remarks: LK20 is subdivided into three subzones.

\section{Subzone LK20A}

Top: LAD of short-lived acme of Cyclagelosphaera margerelii [this study].

Base: FAD of common Zeugrhabdotus scutula [Bown et al., 1998].

Age: Early Barremian (lower elegans MF Zone).

Remarks: the downhole reappearance of an acme of $C$. margerelii can be correlated to a brief period of anoxia in the Saxony Basin, the Hauptblatterton facies. Gallagher in Bown et al. (1998) considered the base of the Zeugrhabdotus scutula acme to lie below the Hauptblatterton facies. Core data from the West Netherlands Basin and western Saxony Basin indicate the base common occurrence of $Z$. scutula is located within the upper part of the Hauptblatterton facies. A short-lived incursion of Nannoconus pseudoseptentrionalis is characteristic of this subzone from the West Netherlands Basin, Saxony Basin and Speeton elegans ammonite-dated LB1A Beds (Rutledge, pers. comm., 2000). This event has yet to be identified from the Central North Sea. 


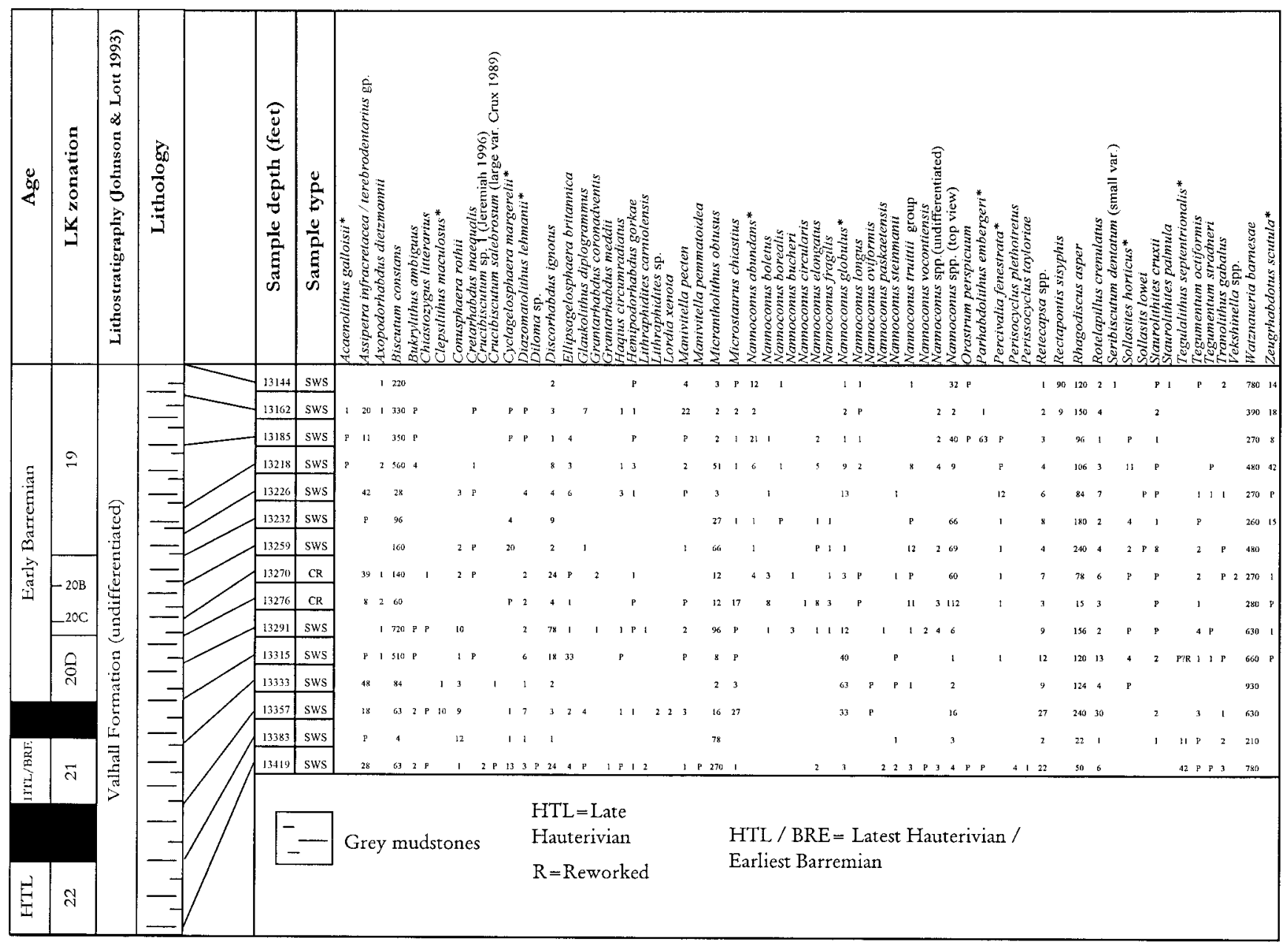

Fig. 19. Stratigraphical distribution of nannofossils from UK Moray Firth Well 15/25a-2 (Early Barremian / Late Hauterivian).

\section{Subzone LK20B}

Top: FAD of common Zeugrhabdotus scutula [Bown et al., 1998].

Base: FAD of short-lived acme of Cyclagelospheara margerelii [this study].

Age: Early Barremian (upper fissicostatum MF Zones).

Remarks: the lower part of the Hauptblatterton facies in the Saxony Basin correlates to the Munk Marl as utilized in the UK North Sea. Samples provided by J. Ineson (Danish Geological Survey) from Danish Well N. Jens-1 have proven that the type Munk Marl (Jensen et al., 1986) is restricted to an intra-LK20B Subzonal age. In the Saxony Basin the LAD of common to abundant Assipetra terebrodentarius is an additional correlative event in the lower part of this subzone.

\section{Subzone LK20C}

Top: FAD of short-lived acme of Cycalgelospheara margerelii [this study].

Base: FAD of Nannoconus abundans [Taylor, 1982].

Age: Early Barremian (lower fissicostatum/rarocinctum MF Zones).

Remarks: Nannoconus abundans has a sporadic occurrence towards the base of its range (Fig. 19) and should be utilized with caution. In cored sections from the Friesland Platform and western margins of the Saxony Basin, onshore Netherlands, $N$. abundans, along with other nannoconid species, is entirely absent from LK20-dated Lower Barremian sediments. Further east into the Saxony Basin nannoconid abundance increases and the FAD of $N$. abundans is found to correlate with the FAD of an incursion of common to abundant Assipetra terebrodentarius. The base of the A. terebrodentarius event is utilized as an alternative LK20C marker in the onshore Netherlands, particularly in the absence of $N$. abundans. In this study, the FAD of $N$. abundans is only utilized as a subzonal marker in contrast to the Zone BC13 application of Bown et al. (1998).

\section{Subzone LK20D}

Top: FAD of Nannoconus abundans [Taylor, 1982].

Base: LAD of Clepsilithus maculosus [Crux, 1989].

Age: Early Barremian (upper variabilis MF Zone).

Remarks: in the North Sea Basin LK20C and LK21 exhibit a low diversity nannoconid assemblage dominated by Nannoconus globulus (Fig. 19), whilst in the Northern North Sea Nannoconus steinmannii, a supposed warm-water indicator, predominates. 
Clepsilithus maculosus Zone - LK21

Top: LAD of Clepsilithus maculosus [Crux, 1989].

Base: LAD of Tegulalithus septentrionalis [Jakubowski, 1987].

Age: earliest Barremian/latest Hauterivian (lower variabilis/ upper gottschei MF Zones).

Remarks: LK21 and LK22 sediments are characterized by the consistent occurrence of abundant Assipetra infracretacea.

\section{Tegulalithus septentrionalis Zone - LK22}

Top: LAD of Tegulalithus septentrionalis [Jakubowski, 1987].

Base: LAD of Eiffellithus striatus [Bown et al., 1998].

Age: Late Hauterivian (gottschei/upper speetonensis MF Zones).

Remarks: the LAD of Tegulalithus septentrionalis is an abrupt event in the North Sea Basin. No differentiation of the NLK14 (FDO T. septentrionalis) and NLK15 (common/abundant $T$. septentrionalis) Zones of Jakubowski (1987) is made. Extremely rare occurrences of $T$. septentrionalis above the common to abundant occurrence are recorded (Fig. 19) but these are, at present, interpreted as reworked.

Nannoconid diversity is generally low with Nannoconus steinmannii predominant. In the Danish Sector of the Central North Sea Parhabdolithus embergeri is common.

Speetonia colligata was utilized by Bown et al. (1998) as a latest Hauterivian marker (intra $\mathrm{BC} 11$ ) above the FDO of $T$. septentrionalis. In the current study $S$. colligata has only been recorded sporadically as high as LK22. Records above the LAD of $T$. septentrionalis may be a result of reworking.

\section{Eiffellithus striatus Zone - LK23}

Top: LAD of Eiffellithus striatus [Bown et al., 1998].

Base: LAD of consistent Crucibiscutum salebrosum [this study]. Age: Late Hauterivian (speetonensis MF Zone).

Remarks: The LAD of Cruciellipsis cuvillieri occurs within this zone.

\section{Cruciellipsis cuvillieri Zone - LK24}

Top: LAD of consistent Crucibiscutum salebrosum [this study]. Base: LAD of common to abundant Cyclagelosphaera margerelii [Jakubowski, 1987] and/or LAD of Calcicalithina oblongata [this study].

Age: Late Hauterivian/latest Early Hauterivian (speetonensis/ inversum MF Zone).

Remarks: this zone can be subdivided into two subzones.

\section{Subzone LK24A}

Top: LAD of consistent Crucibiscutum salebrosum [this study].

Base: FAD of Tegulalithus septentrionalis [Jakubowski, 1987]. Age: Late Hauterivian (speetonensis MF Zone).

\section{Subzone LK24B}

Top: FAD of Tegulalithus septentrionalis [Jakubowski, 1987]. Base: LAD of common to abundant Cyclagelosphaera margerelii [Jakubowski, 1987] and/or LAD of Calcicalithina oblongata [this study].

Age: Late Hauterivian (inversum MF Zone].

\section{Cyclagelosphaera margerelii Zone - LK25}

Top: LAD of common to abundant Cyclagelosphaera margerelii [Jakubowski, 1987] and/or FDO of Calcicalithina oblongata [this study].

Base: LAD of Eprolithus antiquus [Crux, 1989].

Age: Early Hauterivian (inversum to upper regale MF Zone). Remarks: in the southern North Sea and onshore UK sections C. oblongata is absent. Further north, however, this form is characteristic of the Early Hauterivian and probably indicates a connection with Tethyan waters via a proto-Atlantic seaway (Figs 20 and 21). In the Moray Firth the LADs of $C$. oblongata and the C. margerelii acme coincide (Fig. 20). In the North Viking Graben, West of Shetlands Basin and offshore northern Norway the $C$. margerelii acme is sporadic and unreliable as a marker event (pers. obs. and Slinnabanken core in Crux, 1989). Calcicalithina oblongata remains prevalent and is a useful alternative marker in these areas for top LK25.

Secondary markers of correlative significance include the LAD of Stradnerlithus silvaradius towards the top of this zone and the boreal LAD of Helenea quadrata. The nannoconid assemblage is characterized by Nannoconus steinmanni, Nannoconus vocontiensis and Nannoconus cornuta.

Specimens of the ammonite genus, Aegocrioceras sp. (Rawson, pers. comm., 2000, equivalent to the inversum ammonite Zone) were found at the base of the Guildehaus Sandstone (Kemper, 1992) associated with abundant Cyclagelosphaera margerelii, Eiffellithus striata and Crucibiscutum salebrosum in Saxony Basin Well Sleen Dommerskanaal-1 (Adrichem Boogaert \& Kouwe, 1993; 52 $\left.41^{\prime} \mathrm{N} 06^{\circ} 52^{\prime} \mathrm{E}\right)$. Elsewhere in the western Saxony basin (Wells De-Wijk-5 [52 $\left.42^{\prime} \mathrm{N} 06^{\circ} 24^{\prime} \mathrm{E}\right]$,

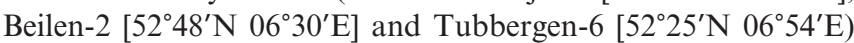
Zone LK25 nannofossil assemblages have also been recorded from core in the lower part of the Guildehaus Sandstone. This is consistent with the identification of a varied Aegocrioceras spp. ammonite assemblage described by Kemper (1992) from the lower Guildehaus Sandstone at Guildehaus, Germany.

\section{Eprolithus antiquus Zone - LK26}

Top: LAD of Eprolithus antiquus [Crux, 1989].

Base: LAD of Triquetrorhabdulus shetlandensis [Bown et al., 1998].

Age: Early Hauterivian (lower regalelamblygonium MF Zones). Remarks: This zone can be subdivided into two subzones.

\section{Subzone LK26A}

Top: LAD of Eprolithus antiquus [Crux, 1989].

Base: FAD of E. antiquus [Crux, 1989].

Age: Early Hauterivian (lower regale/upper amblygonium MF Zones).

Remarks: this zone is characterized by sporadic incursions of common Speetonia colligata, common Cruciellipsis cuvillieri and Sollasites lowei.

\section{Subzone LK26B}

Top: FAD of Eprolithus antiquus [Crux, 1989].

Base: LAD of Triquetrorhabdulus shetlandensis [Bown et al., 1998]. 


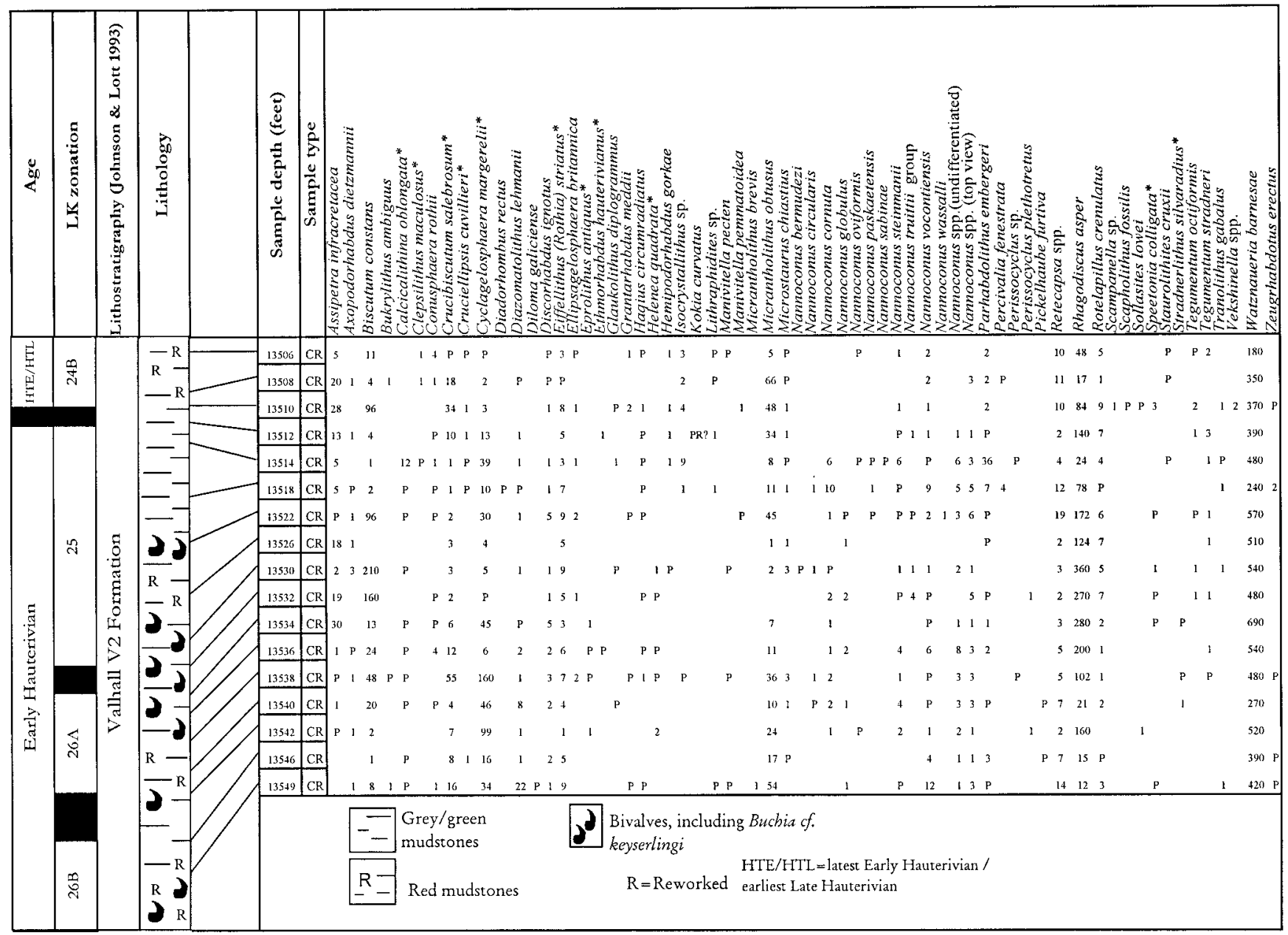

Fig. 20. Stratigraphical distribution of nannofossils from UK Moray Firth Well 15/25a-2 (Early Hauterivian)

Age: Early Hauterivian (lower amblygonium MF Zones).

Remarks: the age of this subzone is confirmed in the western Saxony Basin by Well Westerbork-1 [52 $\left.46^{\prime} \mathrm{N} \quad 06^{\circ} 36^{\prime} \mathrm{E}\right]$ (Adrichem Boogaert \& Kouwe, 1993). Here Endemoceras amblygonium ammonite-bearing sediments (Rawson, pers. comm., 2000) are identified below the FAD of Eprolithus antiquus, a nannofossil confirmed as occurring within upper amblygonium ammonite-dated sediments elsewhere in the Saxony Basin (Moorberg exposure; Crux, 1987). A short-lived quantitative incursion of common to abundant Calculites percernis (holococcolith sp. 1, Crux, 1987) is also an important correlative event of this subzone within the western Saxony Basin.

\section{Triquetrorhabdulus shetlandensis Zone - LK27}

Top: LAD of Triquetrorhabdulus shetlandensis [Bown et al, 1998].

Base: LAD of Micrantholithus speetonensis [Taylor, 1982].

Age: Late Valanginian (unnamed to Dichotomites spp. MF Zones).

Remarks: Bown et al. (1998) utilized the FAD of Conusphaera rothii as a secondary marker for top Valanginian (top BC5). Conusphaera rothii does appear absent from the Valanginian of the North Sea but as alluded to by Crux in Bown et al. (1998), C. rothii is recorded from the Latest Ryazanian (Fig. 22). This zone can be subdivided into two subzones.

\section{Subzone LK27A}

Top: LAD of Triquetrorhabdulus shetlandensis [Bown et al., 1998].

Base: FAD of Eiffellithus striatus [Crux, 1989].

Age: Late Valanginian (unnamed MF Zone).

\section{Subzone LK27B}

Top: FAD of Eiffellithus striatus [Crux, 1989].

Base: LAD of Micrantholithus speetonensis [Taylor, 1982].

Age: Late Valanginian (unnamed to Dichotomites spp. MF Zones).

\section{Micrantholithus speetonensis Zone - LK28}

Top: LAD of Micrantholithus speetonensis [Taylor, 1982]. Base: LAD of common to abundant Nannoconus oviformis and common Kokia curvatalborealis [this study].

Age: Early Valanginian (Polyptychites spp. to Paratollia spp. MF Zones). 


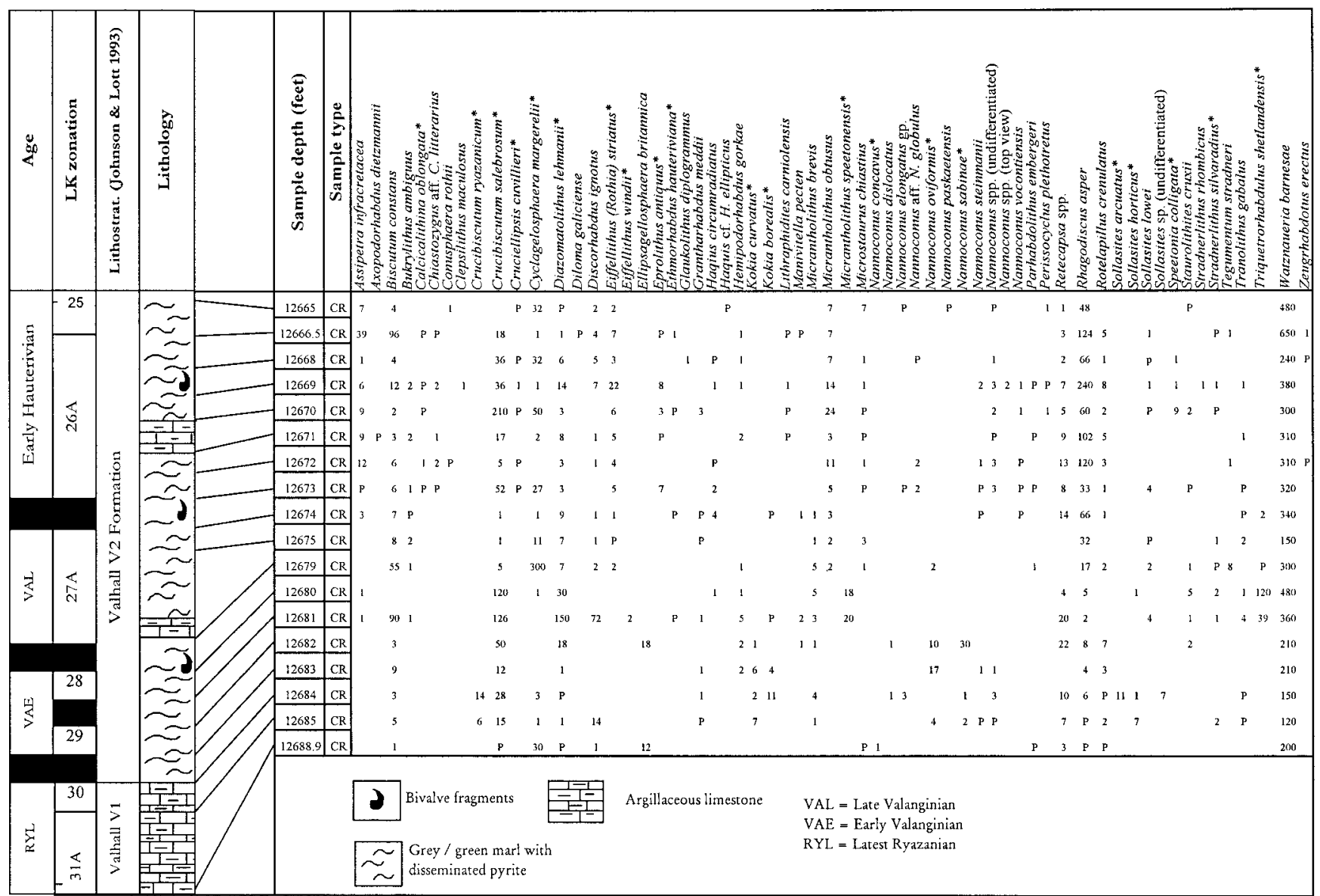

Fig. 21. Stratigraphical distribution of nannofossils from UK Central Graben Well 22/21-4.

Remarks: common Tranolithus gabalus is characteristic of the upper part of this zone in the North Sea Basin. Bown et al. (1998) subdivided this zone based upon the FAD of Eiffellithus windii. This form is generally rare in the Central North Sea and has not been utilized in this study as a reliable correlative datum.

Micrantholithus speetonensis and Triquetrorhabdulus shetlandensis are both recorded from the Platylenticeras beds (Kemper, 1976, 1992) at the base of the marine Lower Valanginian of the Saxony Basin (equivalent to the Paratollia ammonite Zone) in Well Tubbergen-6. A Platylenticeras ammonite (species indeterminate) was recovered from the Platylenticeras beds in Well Westerbork-1 (Rawson, pers. comm., 2000). Equivalent sediments are described in detail by Kemper $(1976,1992)$ from nearby exposure at the Suddendorf Quarry, Bad Bentheim, Germany. Here, both Platylenticeras spp. and Paratollia spp. have been described (Kemper, 1992). The Platylenticeras beds at the Suddendorf clay-pit are unfortunately non-calcareous

\section{Nannoconus oviformis Zone - LK29}

Top: LAD of common to abundant Nannoconus oviformis and common Kokia curvatalborealis [this study].

Base: LAD of Sollasites arcuatus and/or common Crucibiscutum ryazanicum [this study].

Age: earliest Valanginian/latest Ryazanian (lower Paratollia spp. to latest albidum MF Zones).

\section{Sollasites arcuatus Zone - LK30}

Top: LAD of Sollasites arcuatus and/or common Crucibiscutum ryazanicum [this study].

Base: LAD of Nannoconus concavus [this study].

Age: latest Ryazanian (albidum MF Zone).

Remarks: Sollasites arcuatus can be difficult to differentiate from other Sollasites spp. in poorly preserved material. The quantitative influx of $C$. ryazanicum has proven a more reliable datum.

Asymmetrical Crucibiscutum sp. also occur within the Upper Hauterivian (Fig. 19), the Middle Albian (Crucibiscutum sp. 1 of Jeremiah, 1996) and within the lowermost Cenomanian of onshore UK (e.g. Arlesey section, Bedfordshire).

\section{Micrantholithus brevis Zone - LK31}

Top: LAD of Nannoconus concavus [this study].

Base: FAD of Micrantolithus brevis associated with diverse nannoplankton association [this study].

Age: latest Ryazanian (albidum MF Zone).

Remarks: this zone can be subdivided into two subzones.

\section{LKN31A}

Top: LAD of Nannoconus concavus [this study].

Base: FAD of Nannoconus concavus [this study].

Age: latest Ryazanian (albidum MF Zone). 


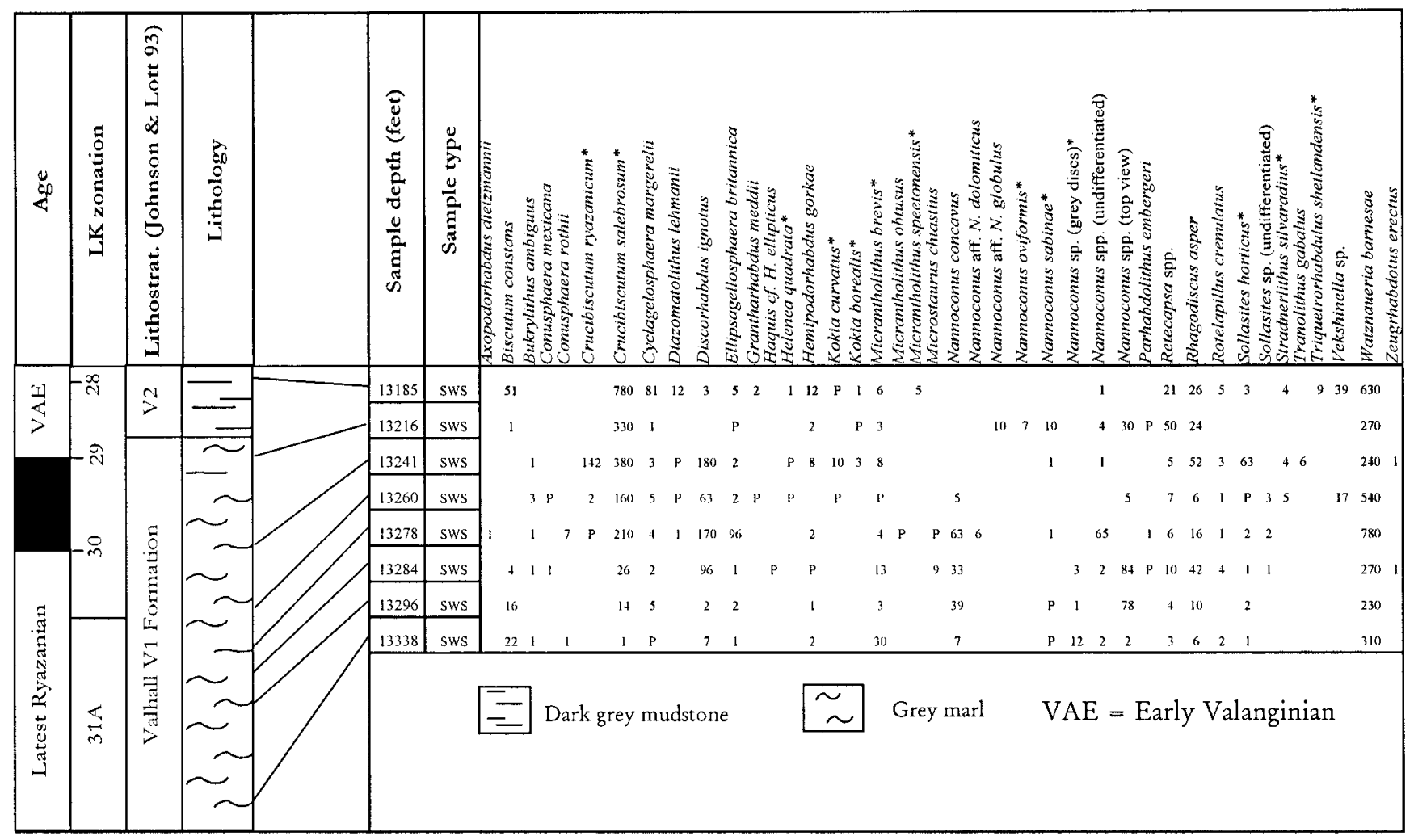

Fig. 22. Stratigraphical distribution of nannofossils from UK Moray Firth Well 21/1b-17.

Remarks: Sollasites arcuatus, Crucibiscutum ryazanicum, Stradnerlithus silvaradius and Kokia spp. have FADs within the upper part of LK31A (Fig. 22). Tethyan connections possibly via a proto-Atlantic Seaway are indicated by the presence of Conusphaera mexicana and Helenea quadrata. The FAD of common to abundant Crucibiscutum salebrosum lies towards the base of this subzone.

\section{LK31B}

Top: FAD of Nannoconus concavus [this study].

Base: FAD of a diverse nannoplankton association [this study]. Age: Latest Ryazanian (albidum MF Zone).

Remarks: the base of this subzone marks a major change in the palaeooceanographic conditions of the North Sea Basin. LKN31B-dated sediments are highly bioturbated exhibiting well oxygenated bottom water conditions. The underlying albidum ammonite-dated Kimmeridge Clay sediments are black, laminated and highly organic. In the Central North Sea these sediments are invariably barren of nannofossils. In the Moray Firth sediments containing stenomphalus zonal ammonites have yielded an extremely low diversity assemblage composed of Watznaueria barnesae, rare Rhagodiscus asper and Cyclagelosphaera margerelii (Block 14/26).

The base of LK31B in a complete section from across this boundary in North Sea well 22/28a-1 (Fig. 1) has shown that this change in nannofossil abundance/diversity is dramatic (unreleased in-house data). The basal $20 \mathrm{~cm}$ of calcareous mudstones above stenomphalus-dated non-calcareous black, organic claystones yield an opportunistic nannofossil assemblage domi- nated by Watznaueria barnesae and Micrantholithus brevis with the remaining nannoflora of low abundance and diversity. Micrantholithus brevis constitutes $50-75 \%$ of the nannoflora when $W$. barnesae is discounted. Nannoconid abundance rapidly increases above this level together with associated placoliths. Parhabdolithus embergeri and Nannoconus spp. (grey discs) are characteristic components of this subzone. The base of LK31B is therefore an environmental base. No evolutionary datum can be firmly fixed at this point. Elsewhere in the world (e.g. Yemen) Ryazanian (Berriasian) sediments remain diverse. It would be impractical to use an evolutionary datum from a Tethyan area and apply it to the North Sea when this datum will probably never be seen. It is for this reason that the base of Retecapsa angustiforata as used by various authors (Jakubowski, 1987; Bown et al., 1998) is not utilized in this study.

\section{TAXONOMY}

A detailed taxonomic section is not provided, although taxa referred to in this paper are listed alphabetically in Appendix A. Taxonomic references not included in the reference list can be found in Bown et al. (1998). New species and combinations are detailed below. LMs are uniformly enlarged at $\times 2300$ $(1.8 \mathrm{~cm}=10 \mu \mathrm{m})$.

Family Biscutaceae Black, 1971

Genus Biscutum Black in Black \& Barnes, 1959

Biscutum constans cavum ssp. nov.

(P1. 1, fig. 4) 

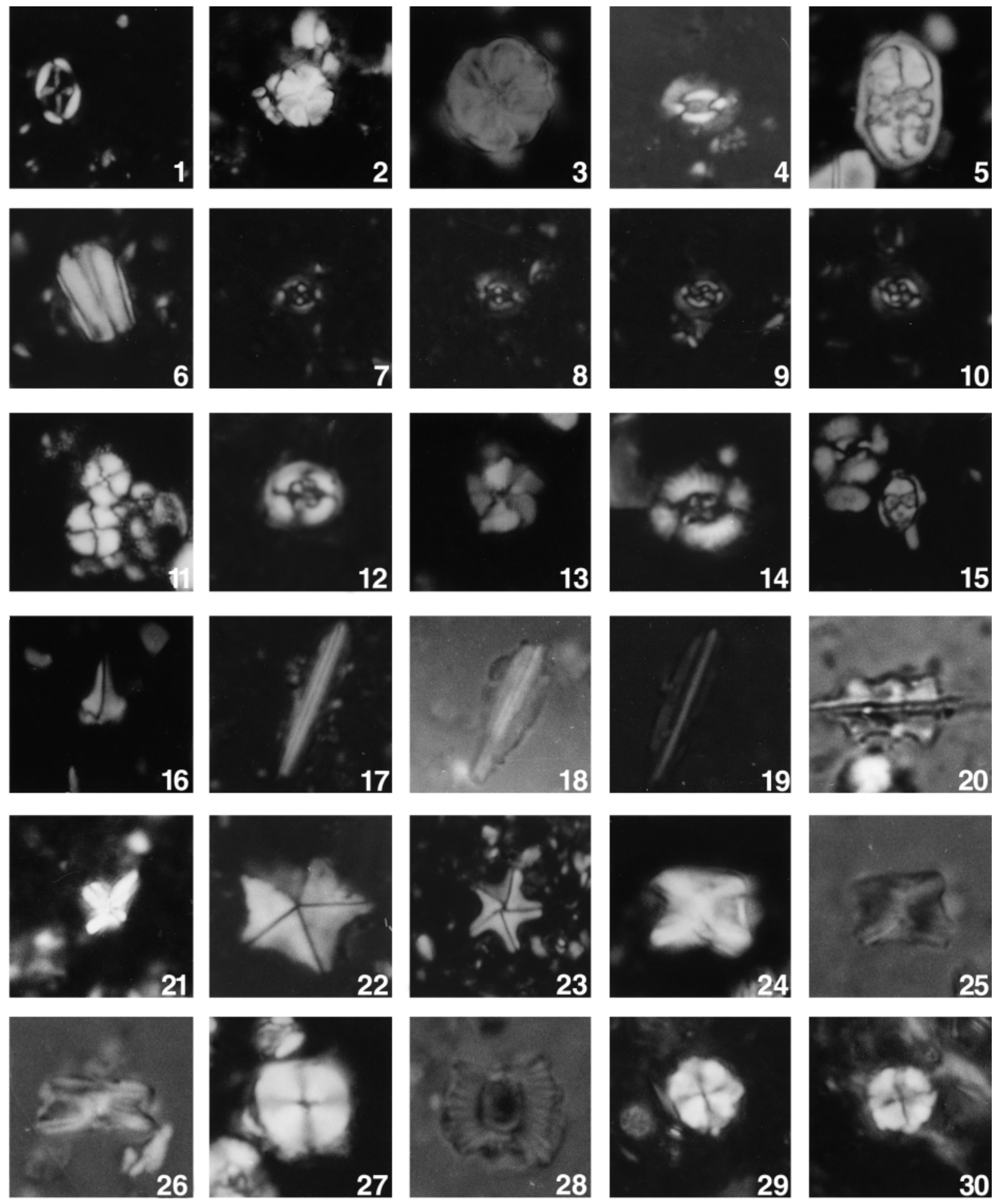
Derivation of name. Latin cavum, meaning hole.

Diagnosis. A large, elliptical Biscutum with two monocyclic shields made of petaloid, non-imbricated elements. The distal shield is non-birefringent, whereas the tube cycle and proximal shield are birefringent under cross-polarized light and surround a large central opening. A central cross has not been observed under phase contrast.

Holotype. SMH-18-25 (Pl. 1, fig. 4); sample material is held in the Micropalaeontology Collections at University College London.

Type locality and horizon. Central North Sea, Valhall V4 (Johnson \& Lott, 1993), Upper Barremian (Zone LK15).

Dimensions. L: $4.5-6.5 \mu \mathrm{m}$ (mean length $5 \mu \mathrm{m}$ ), 50 specimens measured.

Remarks. iscutum constans cavum together with the smaller Biscutum constans quantitatively dominate the low diversity Upper Barremian assemblages of the North Sea area. This Boreal nannofossil assemblage is terminated by the base Aptian transgression and the arrival of cosmopolitan assemblages.

Biscutum constans cavum is characteristic of uppermost Barremian strata from throughout the North Sea Basin.

Genus Crucibiscutum Jakubowski, 1986

Crucibiscutum bosunensis sp. nov. (P1. 1, figs 7-8)

Derivation of name. from the Bosun Field, Outer Moray Firth, North Sea Basin.

Diagnosis. Elliptical placolith with two monocyclic shields and a tube cycle. The distal shield is non-birefringent whereas the tube cycle and proximal shield are birefringent under cross-polarized light. The central cross is axial. Electron microscopy is required to differentiate any fundamental structural differences between C. bosunensis and the morphologically similar C. salebrosum and $C$. hayi. Under light microscopy the central cross of $C$. bosunensis does appear more bulky than in the more open central area of $C$. hayi. At present, however, other than the large stratigraphical displacement between $C$. bosunensis and C. salebrosum it is difficult to differentiate C. salebrosum from C. bosunensis.

Holotype. SMH-19-22 (Pl. 1, fig. 7); sample material is held in the Micropalaeontology Collections at University College London.

Type locality and horizon. Central North Sea, Valhall V7 (Johnson \& Lott, 1993), Upper Aptian.

Dimensions. L: $3.5-5.5 \mu \mathrm{m}$ (mean length $4.5 \mu \mathrm{m}$ ), 50 specimens measured.

Remarks. An influx of $C$. bosunensis is restricted to the Upper Aptian nutfieldensis ammonite Zone in the Central North Sea and is an important correlatable datum. Although morphologically similar to $C$. salebrosum under the light microscope these forms are stratigraphically separated by the Lower Aptian and Barremian.

Crucibiscutum ryazanicum $\mathrm{sp}$. nov. (Pl. 1, figs 9-10)

Derivation of name. From the Ryazanian stage.

Diagnosis. This Crucibiscutum sp. has an asymmetrical central cross.

Holotype. SMH-19-02 (Pl. 1, fig. 9); sample material is held in the Micropalaeontology Collections at University College London.

Type locality and horizon. Central North Sea, Valhall V1 (Johnson \& Lott, 1993), uppermost Ryazanian.

Dimensions. L: $4-5 \mu \mathrm{m}$ (mean length $4.5 \mu \mathrm{m}$ ), 50 specimens measured.

Remarks. An influx of C. ryazanicum together with the axially alligned Crucibiscutum salebrosum is characteristic of uppermost Ryazanian LK30-dated sediments. Crucibiscutum sp. with an asymmetrical cross also occur within the Upper Hauterivian (Fig. 19), the Middle Albian (Crucibiscutum sp. 1 of Jeremiah, 1996) and the lowermost Cenomanian of onshore UK (a late evolutionary development from Crucibiscutum hayi: e.g. the Arlesey section, Bedfordshire).

\section{Explanation of Plate 1}

Fig. 1. Acaenolithus galloisii, crossed-nicols, SMH-18-05; $3215 \mathrm{ft}$ (core), UK 13/22a-2, $3215 \mathrm{ft}$ (LK15). Figs 2-3. Assipetra terebrodentarius: 2, crossed-nicols, SMH-18-12, $12781 \mathrm{ft}$ (core), UK 15/30-3 (LK9B); 3, A. terebrodentarius (large variety), crossed-nicols, SMH-18-12, 11321.2 ft (core), UK 21/2-6 (LK14B). Fig. 4. Biscutum constans cavum, (holotype) crossed-nicols, SMH-18-25, $3215 \mathrm{ft}$ (core), UK 13/22a-2 (LK15). Fig. 5. Calcicalithina oblongata, crossed-nicols, SMH-20-22, $13514 \mathrm{ft}$ (core), UK 15/25a-2 (LK25). Fig. 6. Conusphaera mexicana, crossed-nicols, SMH-20-10, $13284 \mathrm{ft}$ (core), UK 21/1b-17 (LK31A). Figs 7-8. Crucibiscutum bosunensis: 7 (holotype) crossed-nicols, SMH-19-22, 3302.4 m (core), UK 21/1a-12 (LK10); 8, crossed-nicols, SMH-19-20, 3302.4 m (core), UK 21/1a-12 (LK10). Figs 9-10. Crucibiscutum ryazanicum: 9, (holotype) crossed-nicols, SMH-19-02, $13241 \mathrm{ft}$ (sws), UK 21/1b-17 (LK30); 10, crossed-nicols, SMH-19-04, $13241 \mathrm{ft}$ (sws), UK 21/1b-17 (LK30). Fig. 11. Cyclagelosphaera margerelii, crossed-nicols, SMH-21-10, $11117.5 \mathrm{ft}$ (sws), UK 22/26a-2 (LK14B). Fig. 12. Flabellites oblongus, crossed-nicols, SMH-20-06, $29.88 \mathrm{~m}$ (core), Ashford borehole (RC1544), Kent (LK14B). Fig. 13. Hayesites irregularis, crossed-nicols, SMH-19-09, 22.5 m (core), Ashford borehole (RC1544), Kent (LK14B). Fig. 14. Helenea quadrata crossed-nicols, SMH-05-26, 61.32 m (core)-61.4 m (core), BGS borehole 81/43 (LK25). Figs 15-16. Isocrystallithus dispar: 15, crossed-nicols, SMH-22-01, mammillatum MF Zone, Bed UA3, Speeton, Yorkshire (LK7B); 16, crossed-nicols (side-view), SMH-22-08, mammillatum MF Subzone, Bed UA3, Speeton, Yorkshire (LK7B). Figs 17-19. Lithraphidites houghtonii: 17, crossed-nicols, SMH-19-33, $11091 \mathrm{ft}$ (core), UK 22/26a-2 (LK13B); 18 (holotype) bright field, SMH-19-35, 11091 ft (core), UK 22/26a-2 (LK13B); 19, crossed-nicols, SMH-19-36, $11091 \mathrm{ft}$ (core), UK 22/26a-2(LK13B). Figs 20-21. Lithraphidites moray-firthensis: 20, crossed-nicols, SMH-02-22, $890 \mathrm{~m}$ (cuttings), Netherlands P/2-2 (LK11A); 21, crossed-nicols (cross-section), SMH-18-07, 12822 ft (core), UK 15/30-3 (LK11A). Fig. 22. Micrantholithus brevis, crossed-nicols, SMH-20-24, $15619.6 \mathrm{ft}$ (core), UK 22/28a-1 (LK31B). Fig. 23. Micrantholithus stellatus, crossed-nicols, SMH-21-34, $11137 \mathrm{ft}$ (sws), UK 22/26a-2 (LK15). Figs 24-27. Nannoconus concavus: 24, crossed-nicols, SMH-20-18, 13284 ft (sws), UK 21/1b-17(LK31A); 25, bright field, same specimen, SMH-20-19; 26, crossed-nicols, SMH-20-15, $13284 \mathrm{ft}$ (sws), UK 21/1b-17 (LK31A); 27, crossed-nicols (top-view), SMH-20-14, $13284 \mathrm{ft}$ (sws), UK 21/1b-17 (LK31A). Fig. 28. Nannoconus cornuta, crossed-nicols, SMH-20-23, 13514 ft (core), UK 15/25a-2 (LK25). Figs 29-30. Nannoconus pseudoseptentrionalis: 29, crossed-nicols, SMH-20-04, $29.8 \mathrm{~m}$ (core), Ashford borehole (RC1544), Kent (LK14B); 30, crossed-nicols, SMH-20-28, 30.55 m (core), Ashford borehole (RC1544), Kent (LK14B). 

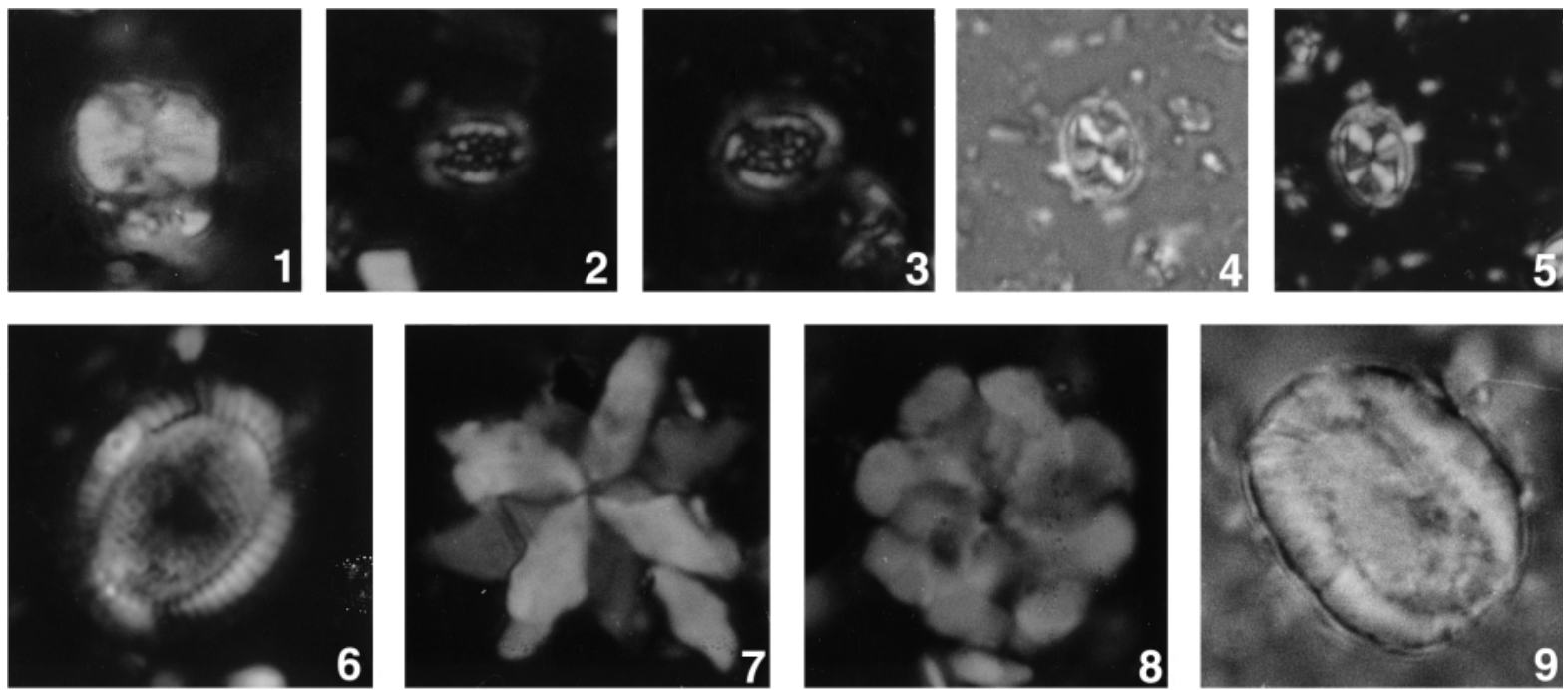

Explanation of Plate 2

Fig. 1. Nannoconus pseudoseptentrionalis (side view), crossed-nicols, SMH-19-12, $1580 \mathrm{~m}$ (core), Norway 31/3-3 (LK15). Figs 2-3. Seribiscutum dentatum: 2, crossed-nicols, SMH-19-14, 9481 ft (sws), UK 21/13b-4 (LK12A); 3 (holotype) crossed-nicols, SMH-19-16, 9481 ft (sws), UK 21/13b-4 (LK12A). Figs 4-5. Staurolithites palmula: 4, bright field, SMH-21-21, $1584 \mathrm{~m}$ (core), Norway 31/3-3 (LK15); 5 (holotype) crossed-nicols, SMH-21-22, 1584 m (core), Norway 31/3-3 (LK15). Fig. 6. Ethmorhabdus hauteriviana (wide rim variety), crossed-nicols, SMH-05-33, 63.5 m (core), BGS borehole 81/43 (LK25). Fig. 7. Kokia borealis, crossed-nicols, SMH-19-28, $12684 \mathrm{ft}$ (core), UK 22/21-4 (LK30). Fig. 8. Kokia curvata, crossed-nicols, SMH-19-31, $12684 \mathrm{ft}$ (core), UK 22/21-4 (LK30). Fig. 9. Nannoconus oviformis, crossed-nicols, SMH-18-27, 12683 ft (core), UK 22/21-4 (LK29).

Genus Seribiscutum Filewicz et al. in Wise \& Wind, 1977

Seribiscutum dentatum sp. nov.

(P1. 2, figs 2-3)

Derivation of name. Latin dentatum, meaning toothed.

Diagnosis. The central area is covered by 'peg-like' granules. A central cross is not observed.

Holotype. SMH-19-14 (Pl. 2, fig. 4); sample material is held in the Micropalaeontology Collections at University College London.

Type locality and horizon. Central North Sea, Valhall V7 (Johnson \& Lott, 1993), lowermost Upper Aptian.

Dimensions Aptian form. L: 6-7 $\mu \mathrm{m}$ (mean length $6.5 \mu \mathrm{m}$ ), 25 specimens measured; Barremian form: L: 3-5 $\mu \mathrm{m}$ (mean length $4.5 \mu \mathrm{m}), 25$ specimens measured.

Remarks. The Aptian form of $S$. dentatum has an extremely restricted occurrence within the basal Upper Aptian, intra Zone LK12 (martinioides Zone). Seribiscutum dentatum reappears downhole in the 'middle' Barremian, Zones LK18/LK19, but at this level is very much smaller than the Aptian form.

Family Microrhabdulaceae Deflandre, 1963

Genus Lithraphidites Deflandre, 1963

Lithraphidites houghtonii sp. nov.

(P1. 1, figs 20-22)

Derivation of name. After the Quaternary nannofossil specialist, Dr S. Houghton.

Diagnosis. Calcareous rods with a cruciform cross-section built of long blades of identical optical orientation. This species has a finely serrated blade. The blade may be quite broad but is generally broken to a more slender shape. The blade serrations are not are not as ordered or as coarse as in Lithraphidites moray-firthensis.

Holotype. SMH-19-33 (Pl. 1, fig. 20); sample material is held in the Micropalaeontology Collections at University College London.

Type locality and horizon. Central North Sea, Valhall V7 and V6 (Johnson \& Lott, 1993), Aptian.

Dimensions. L: 9-12 $\mu \mathrm{m}$ (mean length $11 \mu \mathrm{m}$ ), 50 specimens measured.

Remarks. L. houghtonii has two acme occurrences within the Aptian of the North Sea. Its earliest quantitative incursion occurs within the lower part of the Ewaldi Marl (Valhall V6, Johnson \& Lott, 1993) whilst a later incursion within the martinioides ammonite Zone heralds the evolutionary occurrence of Lithraphidites moray-firthensis.

Family Ahmuellerellaceae Reinhardt, 1965 Genus Staurolithites Caratini, 1963

Staurolithites palmula sp. nov.

(P1. 2, figs 4-5)

Derivation of name. Latin palmula, referring to the blade of an oar.

Diagnosis. Consists of a single zeugoid wall, proximal rim and a central cross without a distal process. The central cross is broad, divided and made of fibrous elements. The central cross is rotated approximately 20 degrees off the principal axes of the ellipse. 
Holotype. SMH-21-22 (Pl. 2, fig. 4); sample material is held in the Micropalaeontology Collections at University College London.

Type locality and horizon. Central North Sea, Valhall V4 (Johnson \& Lott, 1993), Late Barremian.

Dimensions. L: 4-6 $4 \mathrm{~m}$ (mean length $5 \mu \mathrm{m}$ ), 50 specimens measured.

Remarks. This small Staurolithites sp., together with Biscutum constans cavum is characteristic of the Boreal Upper Barremian LK15/LK16 dated Valhall V4 and V5 Beds (Johnson \& Lott, 1993). Staurolithites palmula becomes extremely rare above the basal Aptian transgression but is recorded sporadically as high as the Lower Aptian Ewaldi Marl or Valhall V6.

\section{CONCLUSIONS}

Thirty-one zones are presented which have been calibrated to ammonite stratigraphy. These zones are largely a refinement of previous zonations with a particular emphasis on the re-evaluation of the Lower Albian to Upper Barremian. The resultant zonation is based on a large core and field sample dataset from the Central North Sea Basin, onshore UK, Germany and Netherlands. The stratigraphic significance of many Aptian to Upper Barremian markers such as Lithraphidites moray-firthensis, Farhania varolii, Eprolithus floralis and Nannoconus abundans has been amended.

\section{ACKNOWLEDGEMENTS}

I would like to thank S. Mitchell (University of West Indies) and C. Underwood (University of Liverpool) for collecting samples and helpful observations on ammonite stratigraphy from the Speeton Red Chalk/Clay succession. Peter Rawson (University College London) is also thanked for ammonite identifications from Central North Sea well 22/26a-2, Netherlands onshore boreholes and collection of bidentatum ammonite-dated material from the UB3 Beds at Speeton Cliffs. M. Jakubowski and O. Varol are acknowledged for many fruitful discussions on Lower Cretaceous nannofossil stratigraphy. Matthew Hampton (Network Associates), Liam Gallagher (Network Associates) and two anonymous reviewers gave productive comments on an earlier version of this paper. I would also like to thank London and Continental Engineering for providing material from the RC 1544 borehole, Ashford, Kent and the British Geological Survey for providing core samples from the BGS Heslerton II borehole. Maersk Olie Og Gas has kindly permitted use of data from North-Jens-1 and Jon Ineson (Danish Geological Survey) is thanked for providing samples from the Munk Marl of the same well. I thank Nederlandse Aardolie Maatschappij B.V. (NAM), Shell UK and ESSO UK Ltd for permission to publish this paper.

\section{Manuscript received 28 February 2000 Manuscript accepted 10 January 2001}

\section{REFERENCES}

Aguado, R., Company, M., Sandoval, J. \& Tavera, J. M. 1997. Biostratigraphic events at the Barremian/Aptian boundary in the Betic Cordillera, southern Spain. Cretaceous Research, 18: 309-329.
Aguado, R., Castro, J. M., Company, M. \& Alfonso De Gea, M. 1999. Aptian bio-events-an integrated biostratigraphic analysis of the Almadich Formation, Inner Prebetic Domain, SE Spain. Cretaceous Research, 20: 663-683.

Amedro, F., Damotte, R., Magniez-Jannin, F. \& Manivit, H. 1981. Echelles biostratigraphiques dans l'Albien due Boulonnais (MacroMicro-Nannofossiles). Bulletin d'information des geologues du Bassin de Paris, 18: 3-19.

Adrichem Boogaert, van H. A. \& Kouwe, W. F. P. 1993. Stratigraphic nomenclature of the Netherlands, revision and update by RGD and NOGEPA. Medelingen Rijks Geologische Dienst, $\mathbf{5 0 .}$

Arthur, M. A., Jenkyns, H. C., Brumsack, H. J. \& Schlanger, S. O. 1990. Stratigraphy, geochemistry and paleoceanography of organic carbonrich Cretaceous sequences. In Ginsburg, R. N. \& Beaudoin, B. (Eds), Cretaceous resources, events and rhythms, 75-119. Kluwer Academic, Norwell, Massachusetts.

Below, 1982. Zur Kenntnis der Dinoflagellaten-Zysten-Populationen im Ober-Apt der Tongrube 'Otto Gott' in Sarstedt/Norddeutschland. N. Jahrbuch Geologisches Palaeontographica, Abh, 164(3): 339-363.

Bischoff, G. \& Mutterlose, J. 1998. Calcareous nannofossils of the Barremian/Aptian boundary interval in NW Europe: biostratigraphic and palaeoecological implications of a high resolution study. Cretaceous Research, 19(5): 635-662.

Black, M. 1971. Problematical microfossils from the Gault Clay. Geological Magazine, 108: 325-327.

Black, M. \& Barnes, B. 1959. The structure of coccoliths from the English Chalk. Geological Magazine, 96(5): 321-328.

Bown, P. R., Rutledge, D. C., Crux, J. A. \& Gallagher, L. T. 1998. 5: Lower Cretaceous. In Bown, P. R. (Ed.), Calcareous Nannofossil Biostratigraphy, 86-131. British Micropalaeontological Society Publications Series. Chapman \& Hall, London.

Bralower, T. J., Sliter, W. V., Leckie, R. M., Allard, D. \& Schlanger, S. O. 1993. Dysoxic/anoxic episodes in the Aptian/Albian (Early Cretaceous). Geophysical Monograph, 77: 5-37.

Burnett, J. A. 1998. 6: Upper Cretaceous. In Bown, P. R. (Ed.), Calcareous Nannofossil Biostratigraphy, 132-199. British Micropalaeontological Society Publications Series. Chapman \& Hall, London.

Caratini, C. 1963. Contribution a l'etude des coccolithes du Cenomanien superieur et du Turonien de la region de Rouen. These. Universite d'Alger, Faculte des Sciences, Publication du Labarotoire de Geologique Appliquee, 1-61.

Cobianchi, M., Luciani, V. \& Menegatti, A. 1999. The Selli Level of the Gargano Promontory, Apulia, southern Italy: foraminiferal and calcareous nannofossil data. Cretaceous Research, 20: 255-269.

Crittenden, S., Cole, J. \& Harlow, C. 1991. The Early to 'Middle' Cretaceous lithostratigraphy of the Central North Sea (UK Sector). Journal of Petroleum Geology, 14(4): 387-416.

Crux, J. A. 1989. Biostratigraphy and palaegeographical applications of Lower Cretaceous nannofossils from north-western Europe. In Crux, J. A. \& Van Heck, S. E. (Eds), Nannofossils and their applications, 143-211. Ellis Horwood, Chichester.

Crux, J. A. 1991. Albian calcareous nannofossils from the Gault Clay of Munday's Hill (Bedfordshire, England). Journal of Micropalaeontology, 10(2): 203-222.

Deflandre, G. 1963. Sur les Microrhabdulidés, famille nouvelle de nannofossiles calcaires. Comptes Rendus (Hebdomadaires des Séances) de l'Académie des Sciences, Paris, 256: 3484-3487.

Duxbury, S. 1983. A study of dinoflagellate cysts and acritarchs from the Lower Greensand (Aptian to Lower Albian) of the Isle of Wight, southern England. Palaeontographica, Abt.B, 186: 18-80.

Ennis, W. C. 1932. The upper Beds of the Speeton Clay. Transactions of the Hull Geological Society, 1932: 80-82.

Erba, E. 1994. Nannofossils and superplumes: The early Aptian 'nannoconid crisis'. Paleoceanography, 9(3): 483-501.

Filewicz, M. V. 1977. Mesozoic and Cenozoic calcareous nannofossils recovered by DSDP Leg 36 drilling on the Falkland Plateau, southwest Atlantic sector of the southern ocean. In Wind, F. H. \& Wise, S. R. (Eds), Initial Reports of the Deep Sea drilling Project, 36, 269-491.

Forchheimer, S. 1972. Scanning electron microscope studies of Cretaceous coccoliths from the Kopingsberg borehole No.1, SE 
Sweden. Sveriges Geologiska Undersokning, Series C, No. 668, 65: $1-141$.

Gale, A. S., Kennedy, W. J., Burnett, J. A., Caron, M. \& Kidd, B. E. 1996. The Late Albian to Early Cenomanian succession at Mont Risou, near Rosans (Drome, SE France): an integrated study (ammonites, inoceramids, planktonic foraminifera, nannofossils, oxygen and carbon isotopes). Cretaceous Research, 17: 515-606.

Gallois, R. W. \& Morter, A. A. 1982. The stratigraphy of the Gault of East Anglia. Proceedings of the Geologists' Association, 93(4): 351-368.

Gaunt, G. D., Fletcher, T. P. \& Wood, C. J. 1992. Geology of the country around Kingson upon Hull and Brigg. British Geological Survey Memoir, England and Wales, Sheets 80, 89. HMSO, London.

Heilmann-Clausen, C. \& Thomsen, E. 1995. Barremian - Aptian dinoflagellates and calcareous nannofossils in the Ahlum 1 Borehole and the Otto Gott clay pit, Sarstedt, Lower Saxony Basin, Germany. Geologisches Jahrbuch, Reihe A, 141: 257-365.

Hoedemaeker, P. J. \& Leereveld, H. 1995. Biostratigraphy and sequence stratigraphy of the Berriasian-lowest Aptian (Lower Cretaceous) of the Rio Argos succession (Caravaca, SE Spain). Cretaceous Research, 16: $195-230$.

Jakubowski, M. 1986. New calcareous nannofossil taxa from the Lower Cretaceous of the North Sea. International Nannoplankton Association Newsletter, 9: 52-53.

Jakubowski, M. 1987. A proposed Lower Cretaceous calcareous nannofossil zonation scheme for the Moray Firth area of the North Sea. Abhandlungen der Geologischen Bundesanstalt (Wien), 39: 99-119.

Jeans, C. V. 1973. The Market Weighton structure: tectonics, sedimentation and diagenesis during the Cretaceous. Proceedings of the Yorkshire Geological Society, 39: 409-444.

Jeans, C. V. 1980. Early submarine lithification in the Red Chalk and Lower Chalk of East England: a bacterial control model and its implications. Proceedings of the Yorkshire Geological Society, 43: 81-157.

Jensen, T. F., Holm, L., Franden, N. \& Michelson, O. 1986. JurassicLower Cretaceous lithostratigraphic nomenclature for the Danish Central Trough. Danm. Geol. Unders. Ser. A., 12: 7-65.

Jeremiah, J. M. 1996. A proposed Albian to Lower Cenomanian nannofossil biozonation for England and the North Sea Basin. Journal of Micropalaeontology, 15: 97-129.

Jeremiah, J. M. 2000. Lower Cretaceous turbidites of the Moray Firth: sequence stratigraphical framework and reservoir distribution. Petroleum Geoscience, 6: 309-328.

Johnson, H. \& Lott, G. 1993. Cretaceous of the Central and Northern North Sea. In Knox, R. W. O. B. \& Cordey, W. G. (Eds), Lithostratigraphic nomenclature of the UK North Sea.

Jukes-Browne, A. J. \& Hill, W. 1900. The Cretaceous Rocks of Britain. 1 The Gault and Upper Greensand of England. Memoirs of the Geological Survey of the United Kingdom, 1-499.

Kaye, P. 1964. Some Lower Cretaceous sections in northern England. Proceedings of the Geologists' Association, 75: 315-320.

Kemper, E. 1976. Geologische Führer durch die Grafschaft Bentheim und die angrenzenden Gebiete mit einem Abriß der emsländischen Unterkreide. Nordhorn-Bentheim. Verlag Heimatverein der Grafschaft Bentheim e.V, 1-206.

Kemper, E. 1992. Die tiefe Unterkreide im Vechte-Dinkel-Gebiet (westliches Niedersachsisches Becken). Het Staringmonument Te Losser, $1-95$, (66 plates).

Kennedy, W. J., Gale, A. S., Bown, P. R., Caron, M., Davey, R. J., Gröcke, D. \& Wray, D. S. 2000. Integrated stratigraphy across the Aptian-Albian boundary in the Marnes Bleues, at the Col de Pré-Guittard, Arnayon (Drôme), and at Tartonne (Alpes-de-HauteProvence), France: a candidate Global Boundary Stratotype Section and Boundary Point for the base of the Albian Stage. Cretaceous Research, 21(5): 591-720.

Kirby, G. A. \& Swallow, P. W. 1987. Tectonism and sedimentation in the Flamborough Head region of north-east England. Proceedings of the Yorkshire Geological Society, 46: 301-310.

Mitchell, S. F. 1995. Lithostratigraphy and biostratigraphy of the Hunstanton Formation (Red Chalk, Cretaceous) succession at Speeton, North Yorkshire, England. Proceedings of the Yorkshire Geological Society, 50(4): 285-303.
Mitchell, S. F. \& Underwood, C. J. 1999. Lithological and faunal stratigraphy of the Aptian and Albian (Lower Cretaceous) of the type Speeton Clay, Speeton, north-east England. Proceedings of the Yorkshire Geological Society, 52(3): 269-274.

Mutterlöse, J. 1989. Temperature-controlled migration of calcareous nannofossils in the north-west European Aptian. In Crux, J. A. \& Van Heck, S. E. (Eds), Nannofossils and their applications, 122-142. Ellis Horwood, Chichester.

Mutterlöse, J. 1991. DasVerteilungs - und Migrationsmuster des kalkigen Nannoplanktons in der borealen underkreide (ValanginApt) NW-Deutschland. Palaeontographica, B221: 27-152.

Mutterlöse, J. 1992. Biostratigraphy and palaeobiogeography of Early Cretaceous calcareous nannofossils. Cretaceous Research, 13: 167-189.

Owen, H. G. 1972. The Gault and its junction with the Woburn Sands in the Leighton Buzzard area, Bedfordshire and Buckinghamshire. Proceedings of the Geologists' Association, 83: 287-312.

Owen, H. G. 1975. The Stratigraphy of the Gault and Upper Greensand of the Weald. Proceedings of the Geologists' Association, 86: 475-498.

Perch-Nielsen, K. 1979. Calcareous nannofossils from the Cretaceous between the North Sea and the Mediterranean. In Wiedmann, J. (Ed.), Aspekte der Kriede Europas. International Union of Geological Sciences Series A, 6, 223-272.

Rawson, P. F. \& Jeremiah, J. M. 2001. A Tethyan belemnite, Duvalia, and associated nannofossils from the Upper Barremian (Lower Cretaceous) of the Central North Sea. Proceedings of the Geologists Association, 112: 55-58.

Ruffell, A. H. \& Wach, G. D. 1991. Sequence stratigraphic analysis of the Aptian-Albian Lower Greensand in southern England. Marine and Petroleum Geology, 8: 341-353.

Ruffell, A. H. 1992. Correlation of the Hythe Beds Formation (Lower Greensand Group: early-mid-Aptian), southern England. Proceedings of the Geologists' Association, 103(4): 273-291.

Rutledge, D. C. 1994. Calcareous Nannofossils of the Boreal Lower Cretaceous: Applications in Biostratigraphy and Palaeoceanography. $\mathrm{PhD}$ thesis, University College, London, 325pp.

Rutledge, D. \& Bown, P. R. 1996. New names for old: taxonomic clarification of some Early Cretaceous nannofossil marker species. Journal of Nannoplankton Research, 18: 53-59.

Sissingh, W. 1977. Biostratigraphy of Cretaceous calcareous nannoplankton. Geologie en mijnbouw, 56(1): 37-65.

Taylor, R. J. 1982. Lower Cretaceous (Ryazanian to Albian) calcareous nannofossils. In Lord, A. R. (Ed.), Stratigraphical Index of Calcareous Nannofossils, 40-80. Ellis Horwood, Chichester, for British Micropalaeontology Society.

Thierstein, H. R. 1973. Lower Cretaceous calcareous nannoplankton biostratigraphy. Abhandlungen der Geologischen Bundesanstalt, 29: $1-52$.

Thierstein, H. R. 1976. Mesozoic calcareous nannoplankton biostratigraphy of marine sediments. Marine Micropaleontology, 1: 325-362.

\section{APPENDIX A}

Alphabetical list of species considered in this study. Taxonomic references not included in the reference list can be found in Bown et al. (1998).

Acaenolithus galloisii Black, 1973

Acaenolithus viriosus Jeremiah, 1996

Assipetra infracretacea (Thierstein, 1973) Roth, 1973

Assipetra terebrodentarius (Applegate et al. in Covington \& Wise, 1987) Rutledge \& Bergen in Bergen, 1994

Axopodorhabdus albianus (Black, 1967) Wind and Wise in Wise \& Wind, 1977

Axopodorhabdus dietzmannii (Reinhardt, 1965) Wind \& Wise, 1983

Biscutum constans (Górka, 1957) Black in Black \& Barnes, 1959

Biscutum constans cavum Jeremiah ssp. nov. 
A Lower Cretaceous nannofossil zonation for the North Sea Basin

Biscutum dissimilis Wind and Wise in Wise \& Wind, 1977

Braarudosphaera africana Stradner, 1961

Braarudosphaera batilliformis Troelson \& Quadros, 1971

Braarudosphaera primula Black, 1973

Braarudosphaera quinquecostata Hill, 1976

Braarudosphaera regularis Black, 1973

Braarudosphaera stenorhetha Hill, 1976

Braloweria boletiformis (Black, 1972) Crux, 1991

Broinsonia dentata Bukry 1969

Broinsonia enormis (Shumenko, 1968) Manivit, 1971

Bukrylithus ambiguus Black, 1971

Calcicalithina oblongata (Worsley, 1971) Thierstein, 1971

Calculites anfractus (Jakubowski, 1986) Varol \& Jakubowski, 1989

Calculites dispar Varol in Al-Rifaiy et al., 1990

Ceratolithina bicornuta Perch-Nielsen, 1988

Ceratolithina cruxii Perch-Nielsen, 1988

Ceratolithina hamata Martini, 1967

Chiastozygus litterarius (Gorka, 1957) Manivit, 1971

Clepsilithus maculosus Rutledge \& Bown, 1996

Conusphaera mexicana Trejo, 1969

Conusphaera rothii (Thierstein, 1971) Jakubowski, 1986

Corollithion achlyosum (Stover, 1966) Thierstein, 1971

Corollithion exiguum Stradner, 1961

Corollithion rhombicum (Stradner \& Adamiker, 1966) Bukry, 1969

Cretarhabdus inaequalis Crux, 1987

Cretarhabdus loriei Gartner, 1968

Crepidolithus burwellensis Black, 1972

Cribrosphaerella ehrenbergii (Arkhangelsky, 1912) Deflandre in

Piveteau, 1952

Crucibiscutum bosunensis Jeremiah sp. nov.

Crucibiscutum hayi (Black, 1971) Jakubowski, 1986

Crucibiscutum ryazanicum Jeremiah sp. nov.

Crucibiscutum salebrosum (Black, 1971) Jakubowski, 1986

Crucibiscutum sp.1 Jeremiah, 1996

Crucicribrum anglicum Black, 1973

Cruciellipsis cuvillieri (Manivit, 1966) Thierstein, 1971

Cyclagelosphaera margerelii Noel, 1965

Cyclagelosphaera rotaclypeata Bukry, 1969

Cyclagelosphaera shenleyensis Black, 1973

Diadorhombus rectus Worsley, 1971

Diazomatolithus lehmanii Noel, 1965

Diloma primitiva (Worsley, 1971) Wind \& Cepek, 1979

Discorhabdus ignotus (Gorka, 1957) Perch-Nielsen, 1968

Eiffellithus monechiae Crux, 1991

Eiffellitus (Rothia) striatus (Black, 1971a) Applegate \& Bergen, 1988

Eiffellithus turriseiffelii (Deflandre in Deflandre \& Fert, 1954)

Reinhardt, 1965

Eiffellithus windii Applegate \& Bergen, 1988

Ellipsagelosphaera britannica (Stradner, 1963) Perch-Nielsen, 1968

Eprolithus floralis (Stradner, 1962) Stover, 1966

Farhania varolii (Jakubowski, 1986) Varol, 1992

Flabellites oblongus (Bukry, 1969) Crux in Crux et al., 1982

Gaarderella granulifera Black, 1973

Gartnerago chiasta Varol, 1991

Gartnerago nanum Thierstein, 1974
Gartnerago praeobliquum Jakubowski, 1986

Gartnerago theta (Black, 1959), Jakubowski, 1986

Glaukolithus diplogrammus (Deflandre in Deflandre \& Fert, 1954) Reinhardt, 1964

Gorkaea operio Varol and Girgis, 1994

Grantarhabdus coronadventis (Reinhardt, 1966) Grün in Grün \&

Allemann, 1975

Grantharhabdus medii Black, 1971a

Haqius circumradiatus (Stover, 1966) Roth, 1978

Hayesites albiensis Manivit, 1971

Hayesites irregularis (Thierstein in Roth \& Thierstein, 1972)

Covington \& Wise, 1987

Helenea quadrata (Worsley, 1971) Rutledge \& Bown, 1988

Helicolithus cf. compactus (Bukry, 1969) Varol \& Girgis, 1994

Hemipodorhabdus gorkae (Reinhardt, 1969) Grün in Grün \& Allemann, 1975

Isocrystallithus dispar (Varol in Al-Rifaiy et al., 1990) Rawson \& Jeremiah, 2001

Kokia borealis Perch-Nielsen, 1988

Kokia curvata Perch-Nielsen, 1988

Laguncula dorotheae Black, 1971

Lithraphidites carniolensis Deflandre, 1963

Lithraphidites houghtonii Jeremiah sp. nov.

Lithraphidites moray-firthensis Jakubowski, 1986

Lordia xenota (Stover, 1966) Varol \& Girgis, 1994

Manivitella pecten Black, 1973

Manivitella pemmatoidea (Deflandre in Manivit, 1965)

Thierstein, 1971

Micrantholithus brevis Jakubowski, 1986

Micrantholithus hoschulzii (Reinhardt, 1966) Thierstein, 1971

Micrantholithus obtusus Stradner, 1963

Micrantholithus speetonensis Perch-Nielsen, 1979

Micrantholithus stellatus Aguado in Aguado et al., 1997

Microstaurus chiastius (Worsley, 1971) Grün in Grün \&

Allemann, 1975

Nannoconus abundans Stradner \& Grün, 1973

Nannoconus aquitanicus Deres \& Achéritéguy, 1980

Nannoconus boletus Deflandre \& Deflandre, 1967

Nannoconus borealis Perch-Nielsen, 1979a

Nannoconus bucheri Brönnimann, 1955

Nannoconus circularis Deres \& Achéritéguy, 1980

Nannoconus concavus Perch-Nielsen, 1988

Nannoconus cornuta Deres \& Achéritéguy, 1980

Nannoconus dolomiticus Cita \& Pasquaré, 1959

Nannoconus elongatus Brönnimann, 1955

Nannoconus fragilis Deres \& Achéritéguy, 1980

Nannoconus globulus Brönnimann, 1955

Nannoconus grandis Deres \& Achéritéguy, 1980

Nannoconus longus Perch-Nielsen, 1988

Nannoconus oviformis Perch-Nielsen, 1988

Nannoconus pseudoseptentrionalis Rutledge \& Bown, 1996

Nannoconus steinmannii Kamptner, 1931

Nannoconus truitti Brönnimann, 1955

Nannoconus vocontiensis Deres \& Achéritéguy, 1980

Octocyclus magnus Black, 1972

Orastrum perspicuum Varol in Al-Rifaiy et al., 1990

Owenia hilli Crux, 1991

Parhabdolithus embergeri (Noël, 1965) Stradner, 1963

Percivalia fenestrata (Worsley, 1971) Wise, 1983 
Perissocyclus tayloriae Crux, 1989

Pickelhaube furtiva (Roth, 1983) Applegate et al. in Covington \& Wise, 1987

Prediscosphaera columnata (Stover, 1966) Perch-Nielsen, 1984

Prediscosphaera spinosa (Bramlette \& Martini, 1964) Gartner, 1968

Radiolithus hollandicus Varol, 1992

Repagulum parvidentatum (Deflandre in Deflandre \& Fert, 1954)

Forchheimer, 1972

Rhagodiscus achlyostaurion (Hill, 1976) Doeven, 1983

Rhagodiscus angustus (Stradner, 1963) Reinhardt, 1971

Rhagodiscus asper (Stradner, 1963) Reinhardt, 1967

Rhagodiscus infinitus (Worsley, 1971) Applegate et al. in Covington \& Wise, 1987

Rhagodiscus splendens (Deflandre, 1953) Verbeek, 1977

Rotelapillus crenulatus (Stover, 1966) Perch-Nielsen, 1984

Scampanella spp. Forchheimer \& Stradner, 1973

Scapholithus fossilis Deflandre in Deflandre \& Fert, 1954

Seribiscutum dentatum Jeremiah sp. nov.

Seribiscutum primitivum (Thierstein, 1974) Filewicz et al. in Wise \& Wind, 1977

Sollasites arcuatus Black, 1971a

Sollasites horticus (Stradner et al. in Stradner \& Adamiker, 1966)

Sollasites lowei (Bukry, 1969) Roth, 1970
Speetonia colligata Black, 1971a

Staurolithites angustus (Stover, 1966) Crux, 1991

Staurolithites crux (Deflandre \& Fert, 1954) Caratini, 1963

Staurolithites gausorhethium (Hill, 1966) Varol \& Girgis, 1994

Staurolithites glabra (Jeremiah, 1996) Burnett, 1998b

Staurolithites mitcheneri (Applegate \& Bergen, 1988) Rutledge \& Bown, 1998.

Staurolithites palmula Jeremiah sp. nov.

Stradnerlithus fractus (Black, 1973) Perch-Nielsen, 1984

Stradnerlithus silvaradius (Filewicz et al. in Wind \& Wise, 1977)

Rahmann \& Roth, 1991

Tegulalithus tessellatus (Stradner in Stradner et al., 1968) Crux, 1986

Tegumentum octiformis (Kothe, 1981) Crux 1989

Tegumentum stradneri Thierstein in Roth \& Thierstein, 1972

Tetrapodorhabdus decorus (Deflandre in Deflandre \& Fert, 1954)

Wind \& Wise in Wise \& Wind, 1977

Tranolithus gabalus Stover, 1966

Tranolithus phacelosus Stover, 1966

Watznaueria barnesae (Black in Black \& Barnes, 1959) PerchNielsen, 1968

Zeugrhabdotus scutula (Bergen, 1994) Rutledge \& Bown, 1996

Zeugrhabdotus sisyphus (Gartner, 1968) Crux, 1989

Zeugrhabdotus noeliae Rood et al., 1971 
A Lower Cretaceous nannofossil zonation for the North Sea Basin

\section{APPENDIX B}

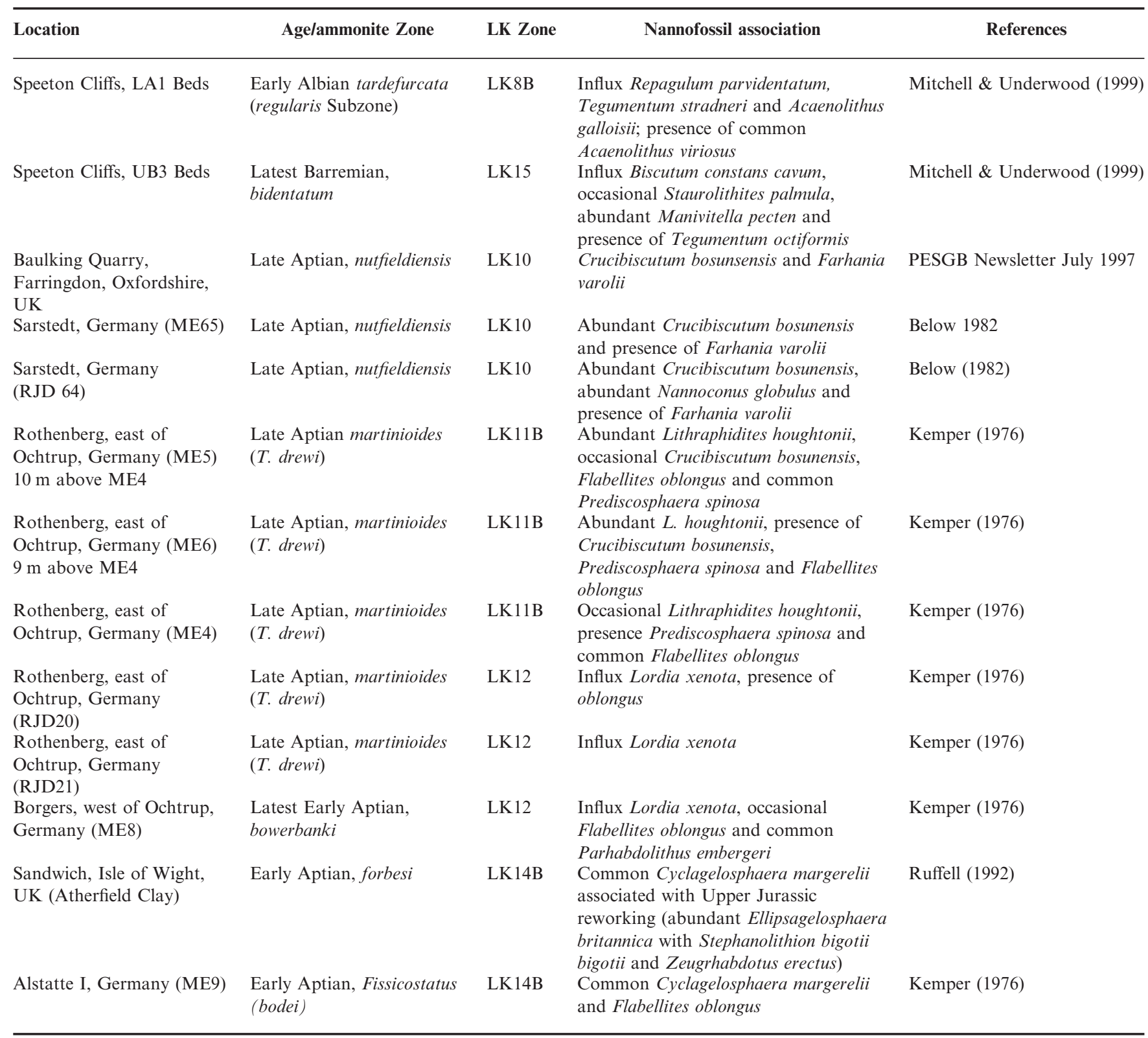

Table B1. Outcrop locations referred to in the paper with relevant references, ammonite calibration and nannofossil assemblages 


\section{APPENDIX C}

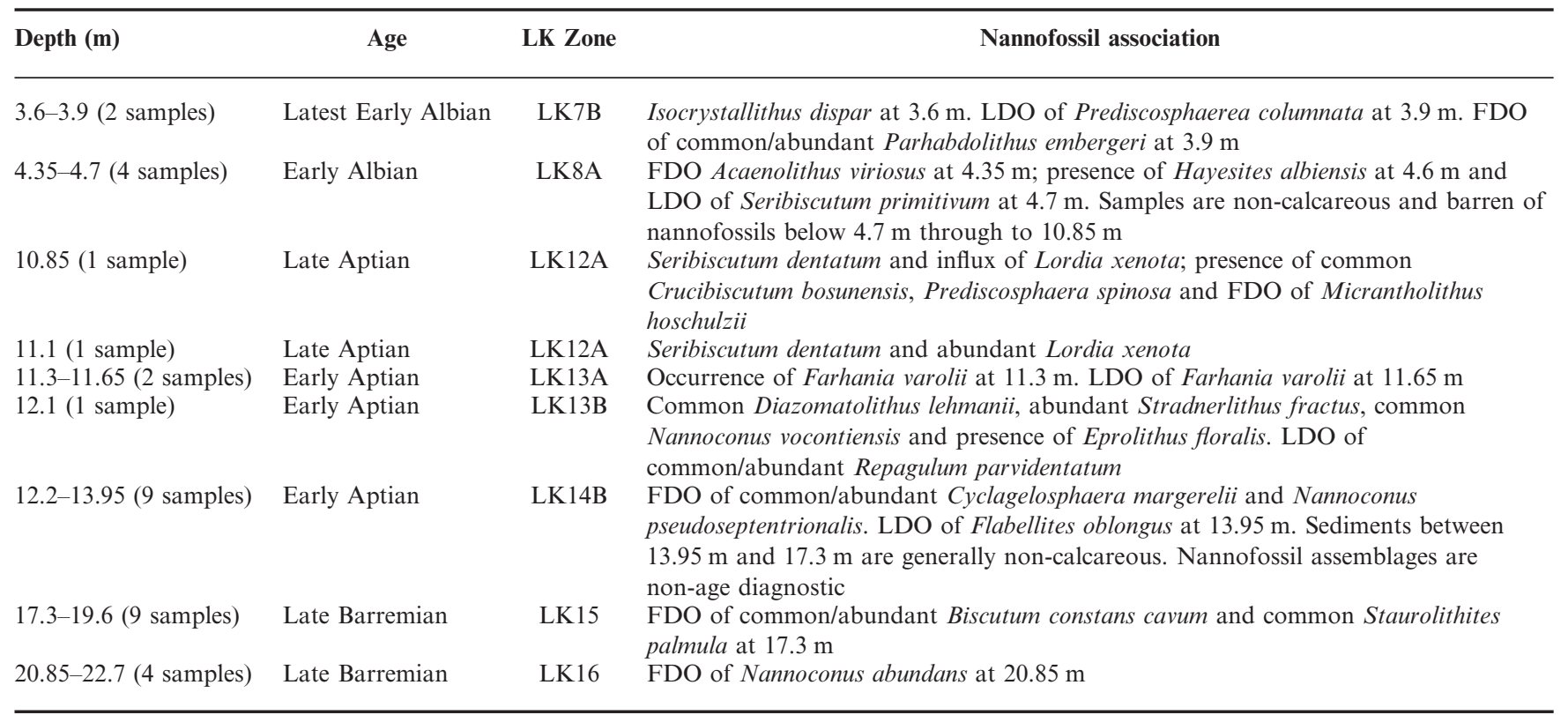

Table C1. Heslerton II Borehole, Yorkshire, UK [SE 9199 7589] 